\title{
Appropriate Transgressions:
}

\section{An Intertextual Approach to Problems of \\ Genre and Heroism in Statius' Achilleid}

\author{
By Hanna Z. C. Mason
}

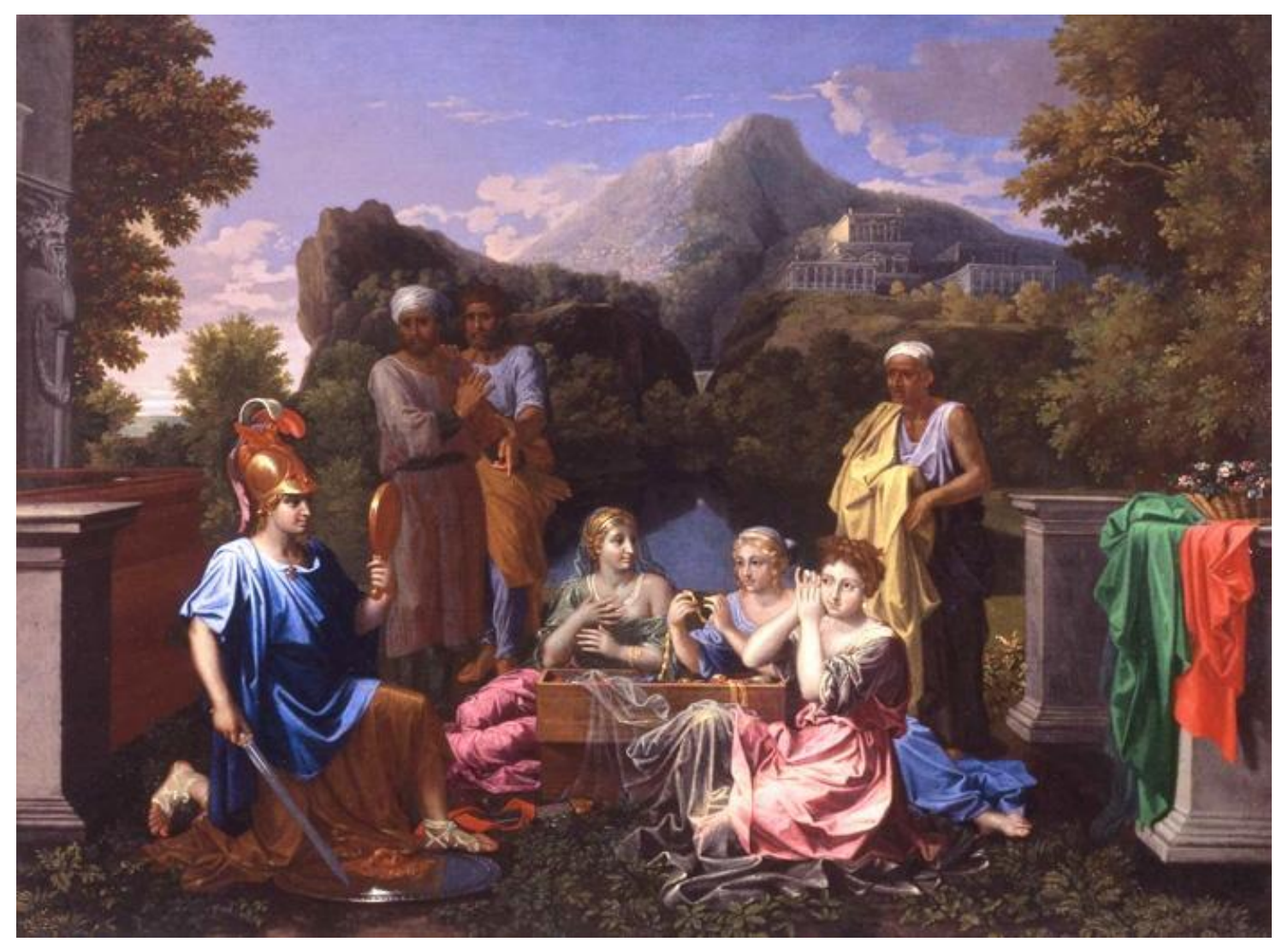

A thesis submitted to the Victoria University of Wellington in fulfilment of the requirements for the degree of Master of Arts in Classics

Victoria University of Wellington 


\begin{abstract}
$\underline{\text { Abstract }}$
Statius' second epic poem, the Achilleid, deals with a subject matter that is particularly problematic: Achilles' early life, in which he is raised by a centaur in the wilderness and then disguises himself as a woman in order to rape the princess of Scyros. Recent scholarship has also pointed to other problematic elements, such as Achilles' troublesome relationship with his mother or the epic's intertextual engagement with elegiac and 'un-epic' poetry. This thesis extends such scholarship by analysing Statius' use of transgression in particular. It focuses primarily upon the heroic character of Achilles and the generic program of the Achilleid as a whole.

The first chapter focuses upon Achilles' childhood and early youth as a foster child and student of the centaur Chiron. It demonstrates that the hero's upbringing is used to emphasise his ambiguous nature in line with the Homeric Iliad, as a hero who is capable of acting appropriately, but chooses not to. Achilles' wild and bestial nature is emphasised by its difference to the half-human character of Chiron, who might be expected to be act like an animal, but instead becomes an example of civilisation overcoming innate savagery, an example of what Achilles could have been. The second chapter discusses the ambiguities inherent in a study of transgression, in the light of Achilles' transvestite episode on Scyros. Numerous intertextual allusions construct various sets of expected behaviours for the transvestite youth, but his failure to live up to any of them portrays him as a truly transgressive hero. In this way, he is similar to Hercules or Bacchus, whose heroism is constructed partly upon their transgressive natures and inability to conform to societal custom. In the final chapter, the study of transgression is extended to Statius' generic program, associating the epic with elegy. Statius employs many elegiac tropes, and makes numerous allusions to the poetry of elegists such as Ovid and Propertius. In particular, elegiac poetry's peculiar trope of constructing and emphasising boundaries in order that they may be crossed (thus making the poetry feel more transgressive) is mirrored in the Achilleid. In this way, the Achilleid's engagement with transgression is considered to be, in part, a method for presenting an innately problematic hero to Statius' Flavian audience in an accessible and interesting manner.
\end{abstract}




\section{To my sisters,}

Gemma, Kathryn, and Rhiannon,

who all inspire me more than they will ever know. 


\section{Contents}

Acknowledgements

$\mathrm{V}$

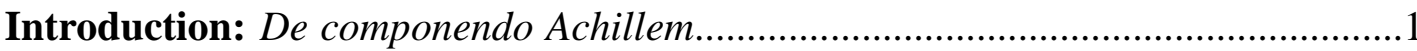

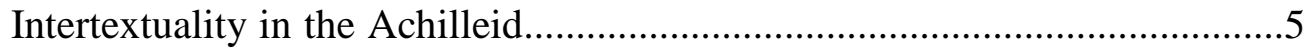

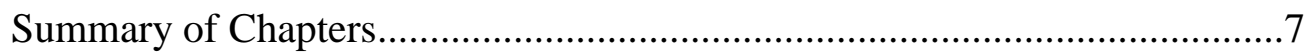

Chapter One: The Nature and Education of Achilles............................................

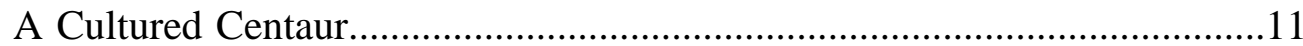

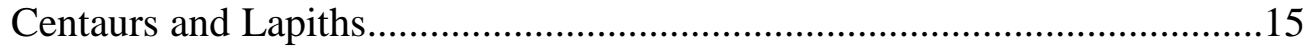

The Ambiguities of Thetis' Dream.............................................................20

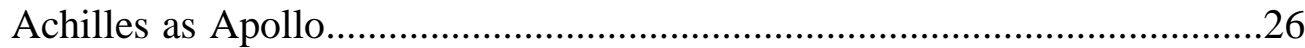

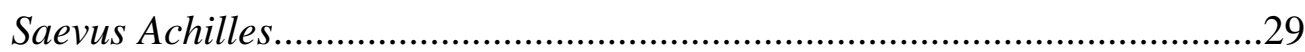

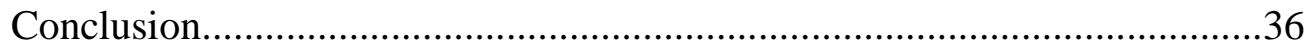

Chapter Two: Layers of Transgression in Rape and Ritual....................................38

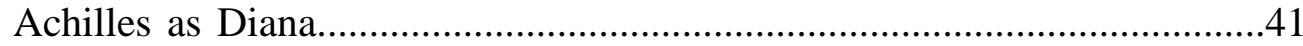

Maenadic Maidens of Scyros....................................................................44

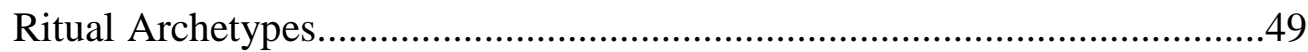

Bacchus, Hercules, and the Bona Dea........................................................58

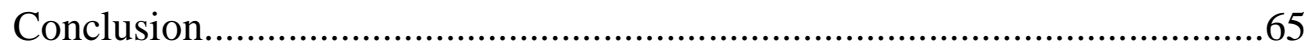

Chapter Three: Elegiac Themes in the Achilleid...................................................67

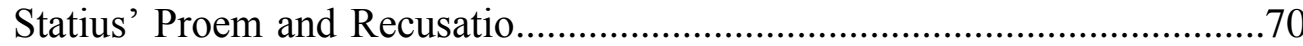

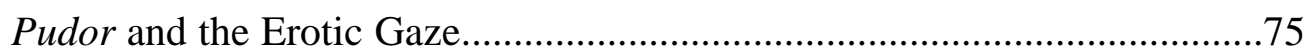

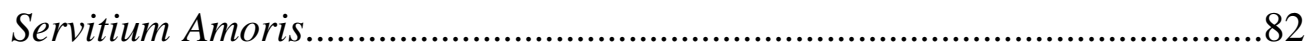

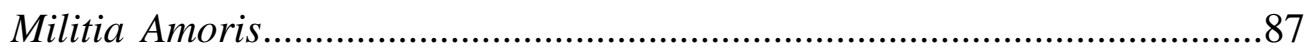

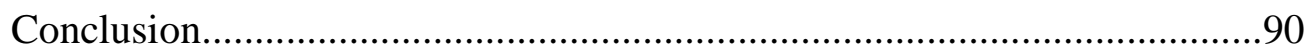

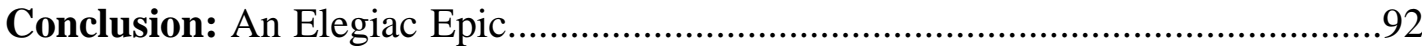

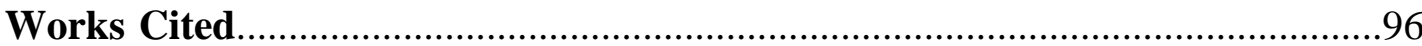




\section{Acknowledgements}

Particular thanks are due to my supervisors, Professor Art Pomeroy and Dr Mark Masterson. They each played a part in inspiring this topic several years ago, and their advice, criticism and moral support throughout my time at Victoria and especially in the past two years has improved this work to no end. I am honoured that they agreed to take me on as student.

I would also like to thank my markers, Professor William J. Dominik and Dr Simon Perris, for the work that they did in assessment. While I am still very aware that this revised thesis is not perfect, it is significantly more polished thanks to the superbly detailed corrigenda and well-considered revisions that they recommended. Their efforts have also given me food for thought in my future work.

Thanks are also owed to the many other lecturers, post-graduates, and former post-graduates of Victoria University's Classics department. In particular, I would like to thank Dr Judy Deuling, Dr Peter Gainsford, Jen Oliver, Daniel Diggins, Alexandra Donnison, Christabel Marshall, and Chris de Lisle. All of these people played a role, either in editing and sanity-checking parts of this thesis, or in supporting me emotionally. I hope they can forgive my stubbornness, and know that the work they have done is greatly appreciated.

Finally, thank you to my parents, and to Matthew Oswin, who deserves as much credit for the good in these pages as I do, although he never read a word.

The cover image is a photograph of Poussin's Achilles on Scyros, painted in 1656. Image source: http://upload.wikimedia.org/wikipedia/commons/7/75/Poussin__1656__Achilles_on_Skyros.jpg (accessed $9^{\text {th }}$ April 2013). 


\title{
Introduction: De componendo Achillem
}

\author{
torpor est nostris sine te Camenis \\ tardius sueto venit ipse Thymbrae \\ rector et primis meus ecce metis \\ haeret Achilles.
}

Silv. 4.7.21-24

My muses are numb without you, the Thymbrian ruler (Apollo) himself comes slower than he is accustomed to, and behold, at the first turning posts my Achilles hesitates. ${ }^{1}$

Statius' second epic, the Achilleid, was begun following the completion of the Thebaid, in the early-mid 90s CE. Though the first lines reveal an intention to tell the entirety of Achilles' life ("ire per omnem... heroa velis"2 - "may you wish to go through the whole hero", Ach. 1.4-5), upon the poet's death in approximately $96 \mathrm{CE}$ only the first book and the beginning of the second were completed. The stanza from Silvae 4.7 above may reveal something of the challenge of this project; while Statius is certainly intending to flatter his patron-addressee, Vibius Maximus, it is not difficult to see why even such an experienced poet might - hypothetically - be having problems with an Achilleid. As the subject of the Iliad, Achilles is the first great hero of the Classical literary tradition, even as his place in the mythic tradition (as the son of Peleus and one of the Greeks sacking Troy for the second time) makes him one of the last great heroes. For a poem that entirely subsumes the events of the Iliad, there is a fine line between writing in Homer's shadow and hubristically attempting to outdo him, and Statius' preeminence in the literary world of the late first Century only goes so far. ${ }^{3}$

Regardless of the reason for its incompletion, the portrait of Achilles' youth that the Achilleid provides is so beautifully self-contained that it has been called "Statius' final masterpiece."4 Beginning in medias res, the epic tracks Achilles as he is taken by Thetis from Chiron's cave in Thessaly, dressed in women's clothing, and deposited among the daughters of King Lycomedes on Scyros. Attending a Bacchic religious festival supposedly off-limits to men, Achilles rapes the princess Deidamia,

\footnotetext{
${ }^{1}$ All translations are my own.

${ }^{2}$ I have used the text of Dilke's 1954 edition of the Achilleid, except where I have noted otherwise.

${ }^{3}$ Cf. Heslin (2005, xi-xii), who argues that Statius "in no way intended to compete directly with Homer."

${ }^{4}$ Heslin (2005), $62 \mathrm{ff}$.
} 
and conceives a son. He remains in women's clothing until the arrival of Ulysses and Diomedes, who have been sent to Scyros to find the young hero and convince him to accompany the Achaeans to Troy. The second book opens with the heroes' immediate departure from Scyros, and while on their way to Troy Achilles returns to the true beginning of the tale, recounting his childhood under Chiron, and finishing the poem with a cyclical (and metapoetical) return to Thetis: "scit cetera mater." ("My mother knows the rest." Ach. 2.167)

Achilles' transvestism and rape of Deidamia are the most blatantly problematic episodes of his youth, but they are only the beginning of the Achilleid's complications. To begin with, Statius' Achilles is a complex hero in general, constructed in a way that carefully juxtaposes him with dichotomies of animalism and civilisation, divinity and mortality, and gender inversions. The poem as a whole mirrors these difficulties through generic tension, manipulating violent epic themes in a manner often more reminiscent of shorter amatory poetry. ${ }^{5}$ The text itself is also filled with allusions and reminiscences of earlier Latin literature, from Ovid and Virgil to Propertius, Catullus, and even Seneca, creating a nuanced and multivalent work that rewards cultural and literary awareness with interest, colour, and confusion. This thesis will examine some of these issues, arguing that Achilles is an innately transgressive hero, that Statius emphasises his transgressive nature through the imposition of numerous boundaries (all of which are crossed), and that the epic's heavy reliance on elegy serves not only to emphasise the amatory elements of his transgression, but to make the problematic late Bronze Age hero more accessible to a Flavian audience. ${ }^{6}$

One of the difficulties in writing a Latin poem about Achilles lies in reconciling the many contradictory portrayals of the hero's personality, and these issues are only exacerbated by an attempt to write his entire life as a cohesive epic. As Alan Cameron argues, the depiction of Achilles' youth was such a popular subject in

\footnotetext{
${ }^{5}$ Thus Hinds (2000), 241: "the Achilleid... has often seemed to modern critics to be so peculiar as to resist classification as an epic on any comfortable terms whatsoever."

${ }^{6}$ In this I make a point of difference from Benker (1987), who argues that the Achilleid subversively undercuts Domitian. I argue that the Achilleid is a transgressive work, but not necessarily a subversive one. On the other hand, I would argue that describing Statius' Achilles as a liminal figure (as per Heslin (2005), xx and passim) is insufficient to describe his transgression. He is not simply "suspended between masculinity and femininity, humanity and bestiality, mortality and divinity," but rather fully immersed in all of these; for example, he is sometimes transgressively masculine and sometimes transgressively feminine, but not always caught in the middle of the two extremes.
} 
the Roman era that "[a] Flavian Achilleid without Chiron, Deidamia and a bit of crossdressing was unthinkable," and yet the Homeric depiction of his time at Troy also remained a strong strand in the Roman cultural perception of Achilles. ${ }^{7}$ In addition, Achilles is a hero who frequently recurs in a range of genres and mediums, from drama and lyric poetry to art and philosophy. Each of these portrayals contributes to the Achilles-mythos with which Statius engages when writing his epic.

Cameron demonstrates that the Roman story of Achilles' youth, told in art and poetry, is intrinsically controversial - being raised by a centaur, dressing in women's clothing, and falling in love with a princess - and yet also that being so controversial does nothing to decrease its popularity. Importantly, however, he establishes that the manner of this depiction was not predetermined, arguing that, "Statius did his best to keep childhood, centaurs and even love within fairly narrow limits." ${ }^{8}$ It is, of course, impossible to know how the epic would have progressed, but this thesis will argue that there is little attempt to avoid the transgressions of Achilles' youth. While most of the episodes leading up to the Trojan War are dealt with in a little over a thousand lines, Statius' approach to these episodes highlights their inherent problematism rather than deemphasising it. For Statius, the unity of Achilles' polysemous character lies primarily in his transgressive nature.

The problematic side of Achilles' youth is clear in a Roman context, but his problematic nature in the Iliad is similarly well-known - if not more so. First and foremost he turns on his own society, asking his mother to beg Zeus to help the Trojans (Il. 1.407-8) and displaying a marked reluctance for any heroics that may cost him his life or contribute to the efforts of his allies (e.g. Il. 9.408-17). Even when he eventually returns to battle, his passionate fury causes him to not just kill Hektor and the Trojans but to try to annihilate them, feeding Lykaon to the fish (Il. 21.126ff), filling the sacred Scamander with corpses (Il. 21.218-21), and repeatedly mutilating Hektor's body (Il. 24.14-18). ${ }^{9}$ His brutal disrespect for those he has killed goes so far beyond the nomoi of his society that his inhumanity begins to appear not god-like, but

\footnotetext{
${ }^{7}$ Cameron (2009), 18. Cf. Horace Ars Poet. 119-22, which will be discussed further in the first chapter.

${ }^{8}$ Cameron (2009), 20.

${ }^{9}$ I have generally used Latinised forms of mythological names, except when they are taken directly from a Greek text - thus Ulysses is a character in the Achilleid and Odysseus is the hero of the Odyssey, but they both represent the same figure.
} 
sub-human. ${ }^{10}$ While the sympathy he shows towards Priam at the end of the epic does restore his humanity to some degree, the weight of this reconciliation is so great because the rest of the Iliad implies that Achilles is acting completely out of character.

The Achilles of Statius, even though he is only depicted in his youth, is similarly barely capable of functioning in his own society. While he does not go to the same "pitiless" lengths as in the Iliad's aristeia, he dresses as a woman, violates a religious festival, and rapes a princess. But even beyond the simple events, a close reading of the epic reveals a particular emphasis upon Achilles' problematic side: the Achilleid's depiction of his education under Chiron makes him seem more bestial than human; at Ach. 1.602, he not only violates the Bacchic festival but laughs as he does so; at Ach. 2.27-30, Statius implies that the mere thought of leaving Deidamia makes him reluctant to pursue the Trojan War.

As the Homeric depiction of Achilles might suggest, this depiction of a transgressive hero is not at all unprecedented; the inability of heroes such as Achilles and Hercules to act in accordance with the boundaries of their societies was so common that it may fairly be regarded as a trope. In particular, tragic representations of heroes often focus on the impact that their heroism has on the people around them thus we see the furor of Herakles in Euripides' Herakles Mainomenos or Hercules in Seneca's Hercules Furens, and that of Aias - turned inwards - in Sophocles' Aias. Even in more light-hearted literature the Alkestis presents Hercules' ribaldry as inappropriate and excessive (even if he had been aware of Alcestis' death), and his transvestism and romantic relationships were common subjects in Latin elegy. In fact, a hero's propensity to act outside of cultural norms (whether through violence or transvestism) can often be a prime signifier of his heroism. In the same way that gods are not expected to conform to the same rules as mortals, the proximity of a hero to the divine both highlights and is highlighted by his own extra-ordinary nature. A figure of transgression is certainly not the only model for a hero, but it is one of the key models on which both Homer's Achilles and Statius' Achilles are built. Indeed, it is worth noting that the Achilleid privileges a variety of heroic models for Achilles, such as Hercules, Theseus, and Bacchus, but in problematic ways; Hercules and Bacchus are

\footnotetext{
${ }^{10}$ Cf., for example, King (1987), $13 f f$.
} 
models in their effeminate dress at Ach. 1.260-63, for example, while Theseus is primarily a model through Catullus 64 , in which he abandons Ariadne. ${ }^{11}$

\section{Intertextuality in the Achilleid}

The use of tropes and allusions is a key feature of Statius' construction of a problematic hero. Critical reception of the Achilleid almost inevitably draws heavily upon these intertextual elements, ${ }^{12}$ and a modern intertextual study requires some discussion of the critical techniques used to negotiate the use of allusions and reminiscences between texts. In this study I find the work of Stephen Hinds (Allusion and Intertext, 1998) particularly influential. Hinds discusses a wide range of critical techniques and approaches to a discussion of topoi and allusions that I have employed, and his focus on the Achilleid as a case study makes his work particularly useful for this thesis.

Following the work of a number of late $20^{\text {th }}$ century readers, Hinds privileges the Metamorphoses as a primary intertext, or "code-model", for the Achilleid claiming that it is "a markedly Ovidian, markedly metamorphic epic,"13 an argument which has received much praise. ${ }^{14}$ Conte's terms "code model" and "exemplary model"15 are particularly apt for this dynamic, but nevertheless they are avoided in this thesis. Instead, my focus upon transgression favours definition of the Achilleid in generic terms, exploring the cumulative influence of a range of different intertexts - and different types of intertexts - rather than attempting to define the epic by comparing it systematically to a single text. In this way, it is possible to argue that the Achilleid negotiates the boundaries between epic and elegy not by directly following Ovid's

\footnotetext{
${ }^{11}$ Davis (2006), 139.

${ }^{12}$ Even in the Middle Ages the Achilleid was read alongside Ovid and Claudian (for Ovid, cf. Parkes (2011), for Claudian (de Raptu Proserpinae), cf. Hall (1969) 70-71). The use of the Liber Catonianus as an ethical guide provides an interesting dynamic for the Achilleid if, as I argue, Achilles is such a transgressive figure. A complete study is outside the bounds of this thesis, but the use of the epic as moral philosophy (thus Woods and Copeland (1999), 382-83) does imply some recognition that the Achilleid is engaged with transgression; mores may be depicted by their opposite.

${ }^{13}$ Hinds (1998), 135-44; emphasis is original. Cf. also Rosati (1994).

${ }^{14} \mathrm{Cf}$., for example, the central role Hinds' work plays in the analysis of Feeney $(2004,85)$

${ }^{15}$ Heslin (1998), 142-43. Conte (1986), 31. Cf. also Edmunds (2001).
} 
Metamorphoses (although I do not deny their parallels), but by manipulating elegy's attempted self-definition as the genre of love and transgression. ${ }^{16}$

The diversity of the Achilleid's intertexts is particularly important for an examination of Statius' manipulations of transgression. As my second chapter examines with respect to Achilles' behaviour in a single episode (the Bacchic trieteris), many of the intertextual models that Statius constructs in his epic impose expectations that are not necessarily met. This failure to match expectations is certainly a strong aspect of the very Ovidian passages; Peter Davis clearly demonstrates that Statius' interaction with Ovid's work is frequently marked by the differences between the two epics. ${ }^{17}$ Thus while Statius might be said to follow Ovidian models in a systematic sense, individual loci similes more often engage with other texts (such as the Aeneid, Seneca's tragedies, Catullus, or Propertius), even to such an extent that Ovid's model seems to be deliberately rejected. A central goal of this study is to examine many of the points at which the expectations constructed by intertextual reminiscences diverge from Achilles' behaviour, contributing to the sense that he is a particularly transgressive hero.

Finally, it is worth noting that while the figure of Statius is consistently used as an agent in discussing the construction of the Achilleid, at no point do I intend to argue that his authorial intent can be construed with any degree of certainty. Here I also follow the approach of Hinds, who claims that while a reader's perception or the imagined construction of an author's intention can be a useful analytical tool, it is little more: "meaning is constructed at the point of reception." 18 This axiom itself creates issues for a Classical scholar - particularly in balancing a modern reception of the text alongside any reception of the text by its contemporary educated audience - but it is nevertheless an important caveat of any intertextual study. In this thesis, as has become common, the focus is not upon Statius' intentions, but upon attempting to provide an educated guess as to the likely potential reception of the immediate contemporary audience.

\footnotetext{
${ }^{16}$ Hinds (2000). The dynamics of elegy in the Achilleid are discussed further in the third chapter.

${ }^{17}$ Davis (2006), 141.

${ }^{18}$ Hinds (1998), 49-50. Cf. also Edmunds (2001), 18-23.
} 


\section{Summary of Chapters}

The major focus for this thesis is upon the Achilleid's manipulations of transgression, particularly in the portrayal of Achilles. As has been discussed above, the transgressive nature of Achilles in the Iliad forms the backdrop to Statius' epic, balanced by the Roman interest in the problematic actions of his youth. The importance of creating a character familiar to Statius' audience thus prescribes some attention to transgression, but it will be shown that this attention is not just a token gesture. Instead, the paradigm of a transgressive Achilles is manipulated on a number of levels, from the portrayal of his character and motivations through to the generic program of the entire epic.

The first chapter addresses the transgressive subtext which underscores the Achilleid's depiction of Achilles' education under Chiron at the beginning of each book. It seeks to demonstrate that while Achilles is dressed as a man, Statius emphasises his transgressive potential according to the Homeric model of a violent, bestial Achilles, and to demonstrate that Achilles' innate wildness - a major part of the transgressive heroic model - undercuts Chiron's attempt to turn him into a civilised hero. Thus Achilles' interactions with the centaurs invert the topos of civilisation triumphing over chaos which the centauromachy-mythos often represents; Achilles becomes as wild as - or wilder than - the centaurs themselves. His mother's actions present a similar subtext. While on one level Achilles seems to have great filial respect for Thetis, there is undercurrent of tension in their relationship and her allegories for Achilles portray him as the cub of a wild beast, with a formidable potential. Moreover, Statius emphasises Chiron's mores every time the centaur appears, defining him by his difference from the other centaurs. At its crux, this portrayal juxtaposes Achilles' transgressive behaviour with a display of the triumph of culture and education over innate savagery; he is what Achilles could have been.

The second chapter considers Achilles as a woman, from the beginning of his transvestism to its end, and in doing so it focuses in on many of the ambiguities in Statius' depiction of transgression. Achilles' transvestism is presented to some extent as an attempt by Thetis to subdue his wild nature (and thus a transgressive act that is paradoxically intended to set a boundary for him), but the violent subtext of the Achilleid's depiction of women as bacchants and amazons provides an outlet for Achilles' innate volatility. Achilles' eventual violation of Bacchic ritual and rape of 
Deidamia is the clearest realisation of his transgressive nature, not only in the conventional sense, but also because numerous intertextual reminiscences construct expectations for an educated reader, which Achilles then fails to meet. Finally, the use of Hercules and Bacchus as heroic models encourages Statius' audience to consider Achilles, too, as a transgressive hero, for whom true transgression would rather be a failure to continue to transgress in the manner expected.

The last chapter will consider Statius' use of elegiac tropes, such as servitium amoris and miles amoris, and the way in which the generic uncertainty these tropes create affects the image of a transgressive Achilles. Latin elegy often manipulates Achilles and other Trojan War heroes, but even more commonly it emphasises mores and constructs generic boundaries which are then transgressed and problematised, creating additional interest for a reader. ${ }^{19}$ For these reasons, elegy is an excellent medium for presenting a transgressive hero to a Roman audience; the passionate and problematic nature of the Iliad's Achilles is preserved through an elegiac 'sieve'.

${ }^{19}$ Hinds (2000), 221-36. 


\title{
Chapter One: The Nature and Education of Achilles, the Beast of the Achaians
}

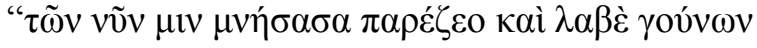

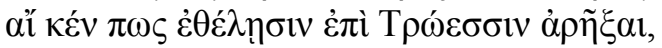

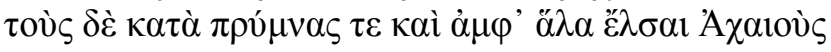

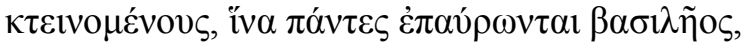

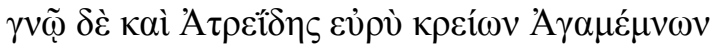

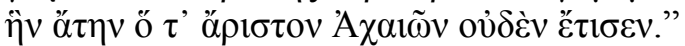

Iliad, $1.407-412$

"Sit beside [Zeus], reminding him of these things (i.e. how you saved him with Briareus), and take hold of his knees, [asking] if in any way he might be willing to give aid to the Trojans, to press the Achaians against the sterns as they are slain, all around the sea, in order that all might reap the reward of their king, and even the Atreid, wide-ruling Agamemnon, might both come to understand his delusion, by which he did not pay his debt to the best of the Achaians."

Aut famam sequere aut sibi conuenientia finge scriptor. Honoratum si forte reponis Achillem, impiger, iracundus, inexorabilis, acer iura neget sibi nata, nihil non arroget armis.

Horace, Ars Poet. 119-122

Writer, either follow the story or devise something consistent with it. If, by chance, you re-write distinguished Achilles, [make him] energetic, raging, relentless, keen; he denies the laws intended for him, he does not claim anything without arms.

The content of the Achilleid raises certain issues for Statius in that Achilles' early life does not fit well with Homer's depiction at Troy. It may be impossible to reconcile Horace's insistence that Achilles be portrayed as "impiger, iracundus, inexorabilis, acer" (Ars Poet. 121) with his transvestite interlude on Scyros, or his varied education under Chiron, which will be discussed further in this chapter. ${ }^{2}$ Yet given the prevalence in early imperial Rome of mythoi related to Achilles' early life, Horace's depiction of Achilles as a hero relying on weapons alone is itself inconsistent in some ways. A truly Roman Achilles, it has been suggested, might be seen (at least to some extent) as a symbol of classical paideia - a hero who evokes "the traditional

\footnotetext{
${ }^{1}$ With thanks to Katherine Callen King and Mark Masterson for this title.

${ }^{2}$ It is worth noting that these inconsistencies of character were an issue for debate in the $18^{\text {th }}$ Century, specifically with reference to this line of Horace, as outlined by Heslin (2005), 16-27.
} 
education of the Greco-Roman world." ${ }^{3}$ The episodes provide a very real opportunity for Statius to present a moral orthodoxy of cultured and athletic youthful beauty.

Nevertheless, as I stated in the introduction, Statius does not present a civilised and well-educated youth, nor a pitiless warrior-hero. ${ }^{4}$ Rather, for Statius' Achilles consistency of character lies primarily in maintaining a transgressive nature that reflects both these models, and yet fully subscribes to neither; too savage for a civilised youth, and too amorous for a pitiless warrior. In fact, this model for Achilles is consistent with the Iliad. As my introduction outlined, there is a clearly transgressive side to the character of Homeric Achilles $;{ }^{5}$ he turns on his own society, displays a marked reluctance for heroics, and acts excessively in every respect: too brutally towards his enemies and too passionately towards his friends. The Iliad questions his human nature, but he often seems as animalistic as he is divine. By the same token, Statius' young Achilles similarly stretches the limits of his society. While he is not as "pitiless" as Homer's Achilles is in the Iliad, his transvestism, violation of ritual, rape of Deidamia, and ambivalence about his warrior-role are similarly transgressive. Statius even maintains an undercurrent of animality to his character despite Chiron's efforts; as Horace claims (Ars Poet. 122), "he denies the laws intended for him".

The last of these problematic elements (Achilles' bestial nature) is the subject of this chapter. It is a theme that has already been considered to some extent, as simple "liminality", by Peter Heslin (2005) in his fourth chapter, "Semivir, Semifer, Semideus". Several of the key aspects of Heslin's work are dealt with here as well for example, the food of Achilles' infancy, or the sadistic and matricidal subtext to his first appearance. Nevertheless, I disagree with Heslin' argument: that Achilles' simultaneously god-like and bestial nature is the result of the absence of Peleus, which causes Achilles to look to Zeus and Chiron as father-figures, "neither of [whom] can

\footnotetext{
${ }^{3}$ Leader (2000), 421-23. Cameron (2009), 11-12 also outlines similar research. Trimble $(2002,245)$ argues that even the more inherently controversial episodes of Achilles' youth have the potential to be read as moralistic tales: "the tablinum paintings [at Pompeii] depict the hero's transcendence of social categories of gender and authority. But in so doing, they articulate those very categories for the viewers of the paintings, and they do so in the context of a social ritual intended to confirm them."

${ }^{4}$ Achilles' character is certainly more nuanced than this, but these are two common approaches.

${ }^{5}$ Cf., for example, King (1987), 13ff.
} 
teach Achilles how to behave as a man." Instead, I argue that Statius depicts Achilles' inhumanity as an attempted emulation of the heroes of his father's era that eventually fails due to his own innately transgressive character rather than poor paternal models. To look at the issue another way, there is something particularly problematic about heroism (including the heroism of Peleus' mythological contemporaries), that causes a disjunction between these heroic figures and their societies. Statius' Achilles, as is his wont (and indeed, his nature as the "best" of the Achaians), simply takes this problematic behaviour to extremes.

Achilles' bestial, problematic nature is particularly apparent in the Achilleid in the depiction of his childhood under Chiron, both when Thetis first arrives to take him to Scyros, and when he describes his childhood to Ulysses and Diomedes on the way to Troy in Book 2. Nevertheless, these sections of the epic do not depict Achilles' problematic behaviour so prevalently because he is emulating the bestial nature of Chiron, but because literary transgressions require the presence of appropriate behaviour in order to be readily apparent; that is, violation of social mores only becomes transgressive when the boundaries which are being crossed are clear. ${ }^{7}$ This chapter will initially demonstrate the way in which Chiron, as a uniquely cultured centaur, acts as the model of appropriate behaviour which he fails to instil in Achilles. From there, I will explore Achilles' attempted emulation of the Lapith heroes (the heroes of his father's era whom Thetis imagines him mimicking at Ach. 1.40-41) and the ways in which this emulation is so problematic. Next, I will show that while he seems to have an appropriate respect for his mother, their relationship has an undercurrent of hostility. Finally, I will examine the potential of Achilles' Chironian (or Apollonian) education to restrain his wild spirit, and yet the way in which Achilles is presented as a failure of that education.

\section{$\underline{\text { A Cultured Centaur }}$}

Statius depicts Achilles' education as a broad range of activities which balance civilised behaviour with preparations for war. When the hero first appears at Ach. 1.159 , he is returning to Chiron's cave after hunting a lioness. He sees his mother,

\footnotetext{
${ }^{6}$ Heslin (2005), 191.

${ }^{7}$ This idea can also be applied to elegy (as per Hinds (2000), 221-36) and the Achilleid's reception of elegy, as the final chapter will explore in more depth.
} 
sweeps her up in an embrace, and then cleans himself up in the stream to prepare for dinner. After the three have eaten, he then plays the lyre and sings to his mother. Until the second book, little more is said of how Chiron has raised him, except for a few brief allusions: it is implied at Ach. 1.312 that he has proper respect for his mother, he is shown teaching Deidamia to play the lyre at Ach. 1.572, and at Ach. 1.624ff he thinks back to his hunting and training for war in Thessaly. It is only in Achilles' own description of his youth to Ulysses and Diomedes that the extent of his active education is made clear. Here he tells of being taught not to fear the wilderness (2.102-5), to live rough (2.106-9), to run fast (2.110-15), to hunt (2.119-28) and to fight (2.129-43), and even to acquit himself in a range of classical athletic activities (2.154-56). Even after all this, however, he claims that he spent just as much time on more peaceful pursuits like playing the lyre, healing, and "the precepts of sacred justice" $(2.156-65){ }^{8}$

The balance between the arts of peace and of war is an essential part of the education of Statius' Achilles, mirroring the breadth of his character in the Iliad. While Achilles' warrior-side is of course the more important for his status as a hero, King highlights his beauty, youth, healing hands, lyre-playing, and mercy for the suppliant (at least in comparison to Agamemnon) as features helping to form the "humanistic complexity" of his character, "[contributing] to the poignancy of the last scene, which takes place under the shadow of Achilles' own imminent death." features of Achilles' character in the Iliad can be attributed to the education and model of appropriate behaviour presented by Achilles' teachers.

\footnotetext{
$8 \quad$ nec maior in istis

sudor, Apollineo quam fila sonantia plectro cum quaterem priscosque virum mirarer honores. quin etiam sucos atque auxiliantia morbis gramina, quo nimius staret medicamine sanguis... ...edocuit monitusque sacrae sub pectore fixit iustitiae, qua Peliacis dare iura verenda gentibus atque suos solitus pacare biformes.

Ach. 2.156-60, 163-65

Nor was there more sweat in these things, than when I made the echoing strings quiver with an Apollonian quill, and marvelled at the ancient glories of men. In fact, he even taught me of potions and plants that aid sickness, [and] by which remedy too much bleeding may be stopped... and he fixed the precepts of sacred justice in my heart, by which he was accustomed to give venerable laws to the peoples of Pelion, and to make peace among his own two-formed folk.

${ }^{9}$ King (1987), 3-13 and 1-2.
} 
The role of Chiron in Achilles' early life is mentioned in the Iliad, but crucially only with respect to his knowledge of healing (Il. 11.828-32). ${ }^{10}$ Instead, Statius seems to use Chiron to also stand in for Phoinix's role in Achilles' education in the Iliad, which is to teach Achilles how to interact with his society in a civilised manner especially through the example of the ancient heroes Achilles wishes to emulate. $I l$. 9.189 sees the embassy of Aias, Odysseus and Phoinix come across Achilles "singing of the glories of men” (“ók1 $\delta \varepsilon \delta$ ’ $\alpha \rho \alpha \kappa \lambda \varepsilon \dot{\alpha} \alpha \dot{\alpha} v \delta \rho \tilde{\omega} v ”)$, and shortly afterward Phoinix attempts to persuade him to relent using those same words ( $\kappa \lambda \dot{\varepsilon} \alpha \dot{\alpha} v \delta \rho \tilde{\omega} v)$ to introduce his mythological exemplum (Il. 9.524ff). This allusion to Achilles' prior singing of $\kappa \lambda \varepsilon \dot{\alpha} \alpha \dot{\alpha} v \delta \rho \tilde{\omega} v$ and playing the lyre not only associates Phoinix with his musical education, but also associates the stories that the young hero sings with moral lessons on how a hero ought to behave in his society. Moreover, Achilles' education in these moral lessons is also ascribed to Phoinix more directly:

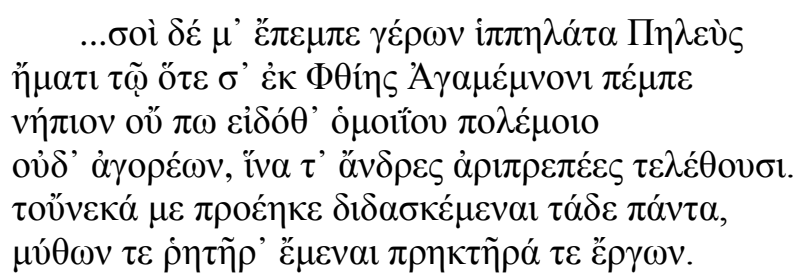

Il. $9.438-443$

But the old driver of horses, Peleus, sent me to you on the day when he sent you to Agamemnon from Phthia, a child, not yet knowing things like war, nor public speaking, through which men become distinguished. For that reason he sent me to teach [you] all these things, [and how] to become both a speaker of words and a doer of deeds.

The construction of this bi-form Homeric education emphasises that a model hero must be able to do deeds that will later become $\kappa \lambda \dot{\varepsilon} \alpha \dot{\alpha} \nu \delta \rho \tilde{\omega} v$, but also must be able to interact with his society in a civilised manner - that is, in the $\dot{\alpha} \gamma o \rho \alpha ́$.

The Achilleid's use of Chiron as teacher of the arts of peace and of war can be seen as a replacement for Phoinix's role in the Iliad, but even this seems to be derived in part from Homer; the emphasis that the Roman tradition places on Chiron's cultured side is also a feature of Iliad. While the centaurs are referred to allusively as " $\varphi \tilde{\eta} \rho \varepsilon \varsigma$

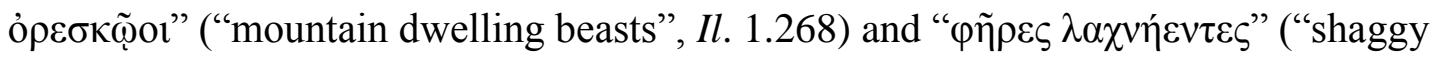

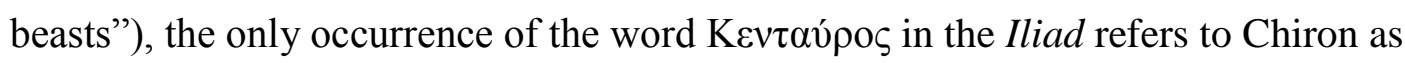

\footnotetext{
${ }^{10}$ Mackie (1997), 4. The Iliad also mentions Chiron giving Peleus' spear to Achilles (16.1404 and 19.387-91), but this provides very little in the way of evidence for the centaur's role in his education.
} 


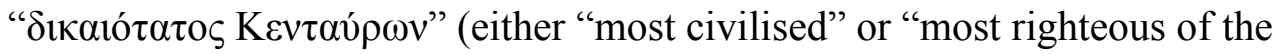
centaurs", ${ }^{11} \mathrm{Il}$. 1.832). The notion of Chiron as the only truly cultured centaur is continued into the Roman era - for example, Cameron cites no fewer than seven extant wall paintings from Pompeii alone showing Chiron teaching Achilles the lyre, and as many instances from literature before or contemporary with Statius. ${ }^{12}$ The Achilleid's description of the centaur's monitus sacrae iustitiae ("precepts of sacred justice" Ach. 2.163-4) preserves the Homeric emphasis on Chiron as a model of appropriate behaviour. ${ }^{13}$

This model of "the cultured centaur" is thus preserved, and yet even alongside this cultured nature, the Achilleid is engaged with Chiron's bestial liminality, prefiguring Achilles' own failure to act appropriately. As a centaur, Chiron is quite literally an ambiguous figure - part human and part animal - and his species is nearly synonymous with the barbarism that their blended physiology implies, bringing notions of uncivilised transgression to the fore. ${ }^{14}$ This is not to say that Achilles' teacher's physiology is what causes the young hero to transgress; rather, Statius portrays Chiron in a way that regularly reminds his audience of the other centaurs; the poet's efforts to illustrate that this centaur does not follow the stereotype of the other centaurs inevitably make barbaric bestiality a subtext to Chiron's civilised nature in the Achilleid. He is defined as much by how he differs from the other centaurs as he is by any action or habit of his own. For example, Heslin notes that Chiron's cave is a combination of artifice and nature, and that it recalls the sexual violence of the centauromachy, and of Peleus' rape of Thetis in Met. 11: ${ }^{15}$

Centauri stabula alta patent, non aequa nefandis fratribus: hic hominum nullos experta cruores spicula nec truncae bellis genialibus orni aut consanguineos fracti crateres in hostes sed pharetrae insontes et inania terga ferarum.

Ach. 1.110-115

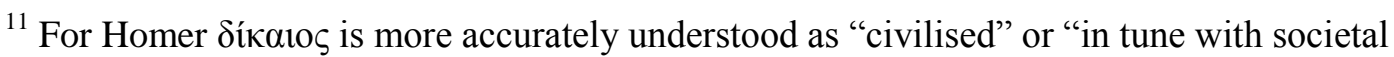
norms" (cf. Lexikon des frühgriechischen Epos (1955), Band 2, 301), though by Statius' time (post Plato's Republic) it may well have been understood as something closer to "righteous" or "just" - and thus intimately connected with the "monitus sacrae iustitiae" Chiron teaches at Ach. 2.163-64.

${ }^{12}$ Cameron (2009), 10-11. Cameron also notes (page 18) that despite his bestial side, "Chiron is invariably represented as a sage, kindly figure, the one good centaur."

${ }^{13}$ Cf. Fantham (1999), 60-61.

${ }^{14}$ This barbaric side to the centaurs can be seen in the Iliad, as mentioned above.

${ }^{15}$ Heslin (2005), 264-66.
} 
...but within extend the lofty stables of the Centaur, not like his unspeakable brothers: here are arrows that have never experienced the blood of men, and there are no ash trees stripped down for nuptial wars or mixing bowls shattered on consanguine enemies, but guiltless quivers and the hollow hides of wild beasts.

This description of Chiron's cave does maintain the cultivated pacifism constructed for the centaur, but Statius' mention of the wild, impious actions of his brethren also alludes to Chiron's own dangerous potential. ${ }^{16}$ Similarly, at Ach. 1.868 Ulysses calls Chiron semiferus in contrast to the feri Centauri, ${ }^{17}$ but this also stresses that he is still part-beast. These ambiguities reinforce Chiron as an archetype of using civilised mores to conquer latent furor, and thus depict him as the perfect teacher for a problematic young hero. However the emphasis placed on the centaur's phenomenal cultured self-control exposes Achilles' reluctance to exert any real control over his own bestial side, and Chiron's ambiguities act as a constant reminder of the centauromachy and those centaurs who did not curb their ferocity. Ironically, these are the centaurs whose behaviour Achilles mimics.

\section{$\underline{\text { Centaurs and Lapiths }}$}

As the description of Chiron's cave might suggest, the centauromachy is a recurring subtext of Achilles' youth and in addition to the centaurs themselves, the Lapiths are also present at several points in the Achilleid - and as role models for Achilles. For example, the first mention of Achilles following the proem sees Thetis imagining her son hoping to emulate or even outdo his father and the Lapiths:

"illic, ni fallor, Lapitharum proelia ludit inprobus et patria iam se metitur in hasta."

Ach. 1.40-41

"In that place [Mt Pelion], if I am not mistaken, the rascal plays at the battles of the Lapiths, and already measures himself against his father's spear."18

In fact, throughout the entire epic Achilles seems to show an intense admiration and enthusiasm for the heroes of his father's era. When Achilles describes the cultural elements of his education to Ulysses and Diomedes, he exclaims: "priscosque virum

\footnotetext{
${ }^{16}$ That is, rather than a locus amoenus, Chiron's cave might be considered an inversion of a locus inamoenus; it is not so much 'pleasant' as 'not unpleasant'.

${ }^{17}$ While this phrase is not used in the Achilleid, the Iliad uses $\varphi \tilde{\eta} \rho \varepsilon \varsigma$ to refer to centaurs at 1.268 and 2.743, as per Robbins (1993), 10.

${ }^{18}$ This spear is presumably the spear that Achilles uses in the Iliad, mentioned at Il. 16.140-4 and 19.387-91, given to Peleus by Chiron himself.
} 
mirarer honores" ("and I marvelled at the ancient glories of men" Ach. 2.156-8). The men to whom he is alluding are presumably those heroes he sings of himself at Ach. 1.188-194: Pollux, Hercules, Theseus, and finally Peleus (at his wedding to Thetis) not-so-subtly foreshadowing his own future glory as a hero of the same calibre. ${ }^{19}$ Similarly, when Thetis attempts to convince Achilles to don women's clothing at Ach. 1.260-64, she uses the examples of two heroes: Hercules and the transsexual Caeneus. ${ }^{20}$ These heroes (the Dioscuri, Hercules, Theseus, and Peleus) were all Lapiths according to various versions (as this section will discuss), and their inclusion as models for Achilles is underscored by the Lapith ambitions which Thetis imagines.

The key role the Metamorphoses plays as an intertext for the Achilleid encourages a reader to associate Ovid's description of the centauromachy with the Achilleid. A verbal parallel may even be noted here, with Thetis' mention of Lapitharum proelia in this passage recalling Ovid's description of the centauromachy at Met. 12.536-7: “inter Lapithas et semihomines Centauros / proelia" ("battles between the Lapiths and the half-human centaurs"). ${ }^{21}$ In addition, Statius' use of biformes to describe the wild centaurs pacified by Chiron at Ach. 2.165 has a distinctly Ovidian flavour, and is paralleled by Ovid's "biformis" at Met. 12.456. ${ }^{22}$ This connection is strengthened by the presentation of Ovid's centauromachy as a side story within his treatment of the Trojan War, narrated by Nestor directly to Achilles himself. Though I will return to the Achilleid shortly, it is worth spending some time on these connections between Ovid's Lapith heroes and Achilles, who may himself be understood as a model for Statius' Achilles. ${ }^{23}$

\footnotetext{
${ }^{19}$ It is worth noting that Theseus, Hercules, and Peleus fought alongside the Lapiths at the wedding of Peirithous (at least as described by Ovid in Met. 12).

${ }^{20}$ Heslin's claim that the example of Caeneus damages Thetis' case by "[exemplifying] the instability of gender" $(2005,122)$ is misplaced, as literal metamorphosis is not a concern for Achilles - this is briefly discussed in my third chapter. In fact, given Achilles' apparent reverence for the heroes of his father's generation, Caeneus makes a very good exemplum for Thetis' cause.

${ }^{21}$ Mendelsohn also makes this connection, although he does not elaborate $(1990,303)$.

${ }^{22}$ biformis (literally "two formed") is not a particularly common word in Latin literature more generally, but even when it is used, it normally describes Janus (e.g. Aen. 6.25) or the minotaur (Fasti 1.89, 5.424). It is rarely used to refer to a centaur except in Ovidian poetry, where it is fairly common - for example, Met. 2.664 (of Chiron), Met. 9.121 (of Nessus being slain by Hercules), and Am. 2.12.19 (of the centaurs fighting the Lapiths).

${ }^{23}$ The presence of the exploits of Caeneus as a central feature of Nestor's centauromachy in the Metamorphoses (as discussed below) may well encourage an audience to associate the texts upon hearing or reading of Caeneus as one of Thetis' four heroic models for gender deviancy in the Achilleid. These cross-references frame the Achilleid as a text that is mutually
} 
After Ovid's Achilles has slain Cycnus, he turns to feasting with the Greeks, marvelling ("mirabile" at 12.165, and "mirabantur" at 12.168) at the invulnerability of Cycnus' body, which turned aside his spears and blunted his sword (12.164-67). ${ }^{24}$ At this point Nestor breaks in to mention that in his own generation (aevo, 12.169 - note that this is also the generation of Peleus) the hero Caeneus was invulnerable in a similar way to Cycnus: ${ }^{25}$

“...Caenea Perrhaebum, qui factis inclitus Othryn incoluit, quoque id mirum magis esset in illo, femina natus erat."

Met. 12.173-175

"...Caeneus of the Perrhaebians, who, famed for his deeds, dwelled on Mt Othrys, and [being invulnerable] is even more wondrous in him; he was born female!

In addition to the mention of Caeneus' transsexualism (which Thetis uses as a model for Achilles at Ach. 1.264, mentioned above), Caeneus is described as a Perrhaebian, from the north of Thessaly. ${ }^{26}$ Perhaps identifying with these features, Achilles enthusiastically begs Nestor to tell the story: ${ }^{27}$

"dic age! nam cunctis eadem est audire voluntas, o facunde senex, aevi prudentia nostri, quis fuerit Caeneus..."

Met. $12.177-179$

"Go on! For all of us wish to hear these things, O eloquent old man, the wisdom of our generation: who Caeneus was..."

In the Metamorphoses alone Achilles shows intense interest in Caeneus, and Nestor emphasises the connections between them further. His tale outlines that Caeneus was from Achilles" own people ("tibi enim popularis, Achille", 12.191), that he was a

compatible with - though not equivalent to - the literary teleology presented by the Augustan poet; in effect, Statius writes a 'prequel' to the presentation of Achilles in the Metamorphoses. Indeed, Ovid himself is telling the stories which are compatible with the Iliad but which Homer generally didn't relate, and the depiction of Aeneas in the Metamorphoses seems to follow similar lines - cf. Hinds (1998), 104-7.

${ }^{24}$ As an aside, it may be worth noting the similarities in approach between Herakles killing the Nemean lion in Pseudo-Apollodorus' Bibl. 2.5.1 and Achilles defeating Cycnus in Met. 12.77143: the heroes first use ranged weapons (Herakles a bow, Achilles a spear), then hand-tohand weapons (Herakles a club, Achilles a sword), and finally resort to wrestling with their opponent, and choking him to death. The parallels between Hercules and Achilles (a recurring theme in this thesis) are not unique to Statius.

${ }^{25}$ Note that Nestor's description of the centauromachy in the Iliad at 1.262-72 also includes Caeneus.

${ }^{26}$ Note too that Statius' Achilles is also invulnerable, except for his heel; Ach. 1.481 describes him as impervious to iron.

${ }^{27}$ Achilles' transvestism on Scyros was a myth common enough in the Roman period (as Cameron (2009) demonstrates) that it may be assumed as Ovid's back-story to Achilles' fascination with Caeneus. 
Lapith at the wedding of Pirithous alongside Peleus and Theseus (12.459ff), and that while he was a woman Peleus might have tried to woo him if not for Thetis (12.19395).

In Ovid's following depiction of the centauromachy, Nestor relates the deeds of the Lapiths to Achilles in detail - and many of the heroes Statius adopts as role models for Achilles are described extensively. Theseus in particular receives pride of place, leaping in to rescue Hippodameia from Eurytus, and is called magnanimus ("great-spirited", Met. 12.230), just as Achilles is described in the opening words of the Achilleid ("magnanimum Aeaciden", Ach. 1.1). Ovid's Ulysses also uses the term to describe Achilles in the speech that wins him the young hero's armour, at Met. 13.298, before going on to describe Achilles' draft-dodging on Scyros. ${ }^{28}$ Moreover, at 12.366-92 Nestor also relates the heroics of Peleus (and relates in depth how the tip of Peleus' hasta (cf. Ach. 1.41) was left in the ribs of a centaur at 12.368-372). While Ovid does not include the Dioscuri among the Lapiths, Hercules is particularly conspicuous by his absence; Nestor refuses to tell of his deeds because he has slain his brothers - all eleven other sons of Neleus (553-55). Nevertheless, he acknowledges that he was there, and Nessus is told: "ne fuge! ad Herculeos... servaberis arcus." ("Do not flee! You will be saved [to die by] the bow of Hercules." 12.309).

As I argued above, Ovid's depiction of the Lapiths in the Metamorphoses can be understood as the "back-story" as it were, to Achilles' reverence for the Lapiths in the Achilleid, and thus it is reasonable to interpret the centauromachy as a subtext to Chiron's heroic education. In a centauromachy, a hero's role is to defend civilised society from the bestial lust and barbarity of monsters such as the centaurs. ${ }^{29}$ Achilles' reverence for these earlier heroes is thus portrayed as an embrace of that defensive, 'civilised' heroism that we might expect of a student of Chiron - the 'civilised' centaur. For example, when Achilles sings about the deeds of the Lapiths, while he does not describe battles with centaurs, ${ }^{30}$ he does sing of heroes subduing beasts and otherwise transgressive figures: of Hercules' labours (ranging from the

\footnotetext{
${ }^{28}$ Dilke (1954), 79. magnanimus has received considerable attention from Dilke and others (e.g. Barchiesi (1996), 47-50, and Heslin (2005), 71-76).

${ }^{29}$ With respect to the centaurs' lust, note that both Nessus and Eurytus attempt to make off with the bride of a hero.

${ }^{30}$ Of course, according to a literary teleology that privileges Ovid's Metamorphoses, he does not know these stories yet!
} 
Nemean lion to the Amazon Hippolyta), Pollux's defeat of the impious King Amycus, ${ }^{31}$ and Theseus' battle with the Minotaur.

There is no clear cut victory of civilisation over barbarism in Statius' depiction of Achilles' heroism, however. Immediately before the hero is finally introduced in person, Chiron relates to Thetis the difficulties he is having with Achilles' behaviour. Achilles is indeed pretending to be a Lapith and playing at battles with the centaurs (as Thetis imagines at Ach. 1.40-41), but his strong desire to emulate his heroic forebears causes him to 'play' on the wrong side:

“...ipsi mihi saepe queruntur

Centauri raptasque domos abstractaque coram armenta et semet campis fluviisque fugari insidiasque et bella parant tumideque minantur. olim equidem, Argoos pinus cum Thessala reges hac veheret, iuvenem Alciden et Thesea vidi..."

Ach. 1.152-157

"The centaurs themselves often protest to me about their homes being pillaged, their herds being dragged off right in front of them, and they themselves being chased from their fields and rivers, and they prepare ambushes and wars, and arrogantly make threats. Indeed once, when the wood of the Argo carried Thessalian kings this way, I saw a young Alcides and Theseus..."

Chiron's concern for Achilles here is clearly not misplaced. While to some degree the young hero is simply copying his Lapith forebears by fighting the centaurs, not to mention foreshadowing his Homeric role as $\pi \tau 0 \lambda i \operatorname{to} \rho \theta 0 v$ ("sacker of cities"), ${ }^{32}$ he is also reversing the typical dynamic of the centauromachy. While the Lapiths fought in self-defence against centaurs who had broken the laws of xenia in attempting to rape the bride at a wedding feast (or in Hercules' case, attempted to abduct Deianira under the pretext of aid), Achilles is acting as the barbaric aggressor in this passage, driving the centaurs from their homes - without provocation - and stealing their herds.

The transgressive image of Achilles that this passage presents is also intensified by the "abstracta... armenta" of Ach. 1.153-4; this mention of stolen herds recalls Vergil's description of Hercules' cattle stolen by Cacus, as "abstractae... boves" at Aen. 8.263. It has been shown that Vergil's depiction of semihomo Cacus is an adaptation of the thief's more bucolic treatment in Hellenistic sources, and highlights his bestiality and barbarity - with the consequence that Hercules' own role

\footnotetext{
${ }^{31}$ Amycus' impiety and bestial nature had been stressed by Valerius Flaccus, who compares him to Polyphemus at Arg. 4.99ff.

${ }^{32}$ Achilles is called this at $I l .8 .372,15.77,21.550$, and 24.108.
} 
as a civilising hero is embellished, rather than his own more barbaric side. ${ }^{33}$ Within the framework of a Latin literary tradition which repeatedly retold the story of Hercules defeating Cacus as a foundation story or aetion for the Ara Maxima ${ }^{34}$ - and by extension, for Rome itself - a depiction of Achilles rustling cattle is certainly problematic.

The centaurs themselves are not entirely innocent here either, of course - they maintain something of their Ovidian volatility (especially in comparison with Chiron) through the ambushes they eventually prepare against Achilles. However they also act more defensively, complaining to Chiron ("queruntur") in the vain hope that he can control Achilles. This action is eventually recalled at the end of Achilles' own depiction of his youth at Ach. 2.163-165, where he explains that the monitus sacrae iustitiae which Chiron instilled in his heart were the same precepts "by which he was accustomed to give venerable laws to the peoples of Pelion, and to make peace among his own two-formed folk." ("qua Peliacis dare iura verenda gentibus atque suos solitus pacare biformes.") Ironically, despite the education that Achilles claims to have received, at this point he is the agent so direly in need of pacification. Chiron's claim, immediately before this passage, that “[Achilles'] hastening strength prepares for some great thing” (“quid magnum... / vis festina parat", Ach. 1.147-8) may be accurate, but this "great thing" is not necessarily a good thing. Statius' audience is thus encouraged to think of Achilles as a terrifying and ineducable force of nature - a danger even to those who are living peacefully around him.

\section{The Ambiguities of Thetis' Dream}

Achilles' first appearance in the Achilleid seems at first to negate Chiron's words. While Thetis is momentarily riveted in place by "icy fear" (Ach. 1.158-61), it seems to be just surprise at how her son has grown. Statius goes on to describe the young hero's beauty as he returns, like, Apollo, from the hunt (Ach. 1.161-68). He throws down his prey and embraces her joyfully, and then heads to the stream to clean himself in preparation for dinner. After they have eaten, he plays the lyre for his mother, finishing with a song about her wedding to Peleus. The idyllic scene seems to

\footnotetext{
${ }^{33}$ Sutton (1977), 391.

${ }^{34}$ For examples, note Aen. 8.102-279, Fasti 1.543-82, Propertius 4.9 (dealt with further in the second chapter), Dionysius of Halicarnassus' Rom. Arch. 1.39-40, and Livy 1.7.3-8.
} 
depict a young hero who has learned how to behave appropriately towards a guest, and with proper filial devotion towards his mother. ${ }^{35}$ A similar devotion is implied at Ach. 1.310-12, as he restrains himself from immediately raping Deidamia, partially out of respect for Thetis. ${ }^{36}$ Nevertheless, the subtext of volatility that Chiron's warning has created is still a subtext to this scene, and the relationship between Achilles and his mother is somewhat more restrained than it first appears. Daniel Mendelsohn outlines that in fact, the language of Achilles' first appearance recalls the imagery of the fictitious dreams Thetis concocts for Chiron as she drags her son away, and the episode depicts both the young hero and his mother problematically. ${ }^{37}$

As I have outlined, when Achilles finally appears at the cave, youthful and beautiful, he has returned from the hunt. However, the object of his hunt is unusual; he has just killed a lioness and stolen her cubs: ${ }^{38}$

forte et laetus adest - o quantum gaudia formae adiciunt! -: fetam Pholoes sub rupe leaenam perculerat ferro vacuisque reliquerat antris ipsam, sed catulos adportat et incitat ungues. quos tamen, ut fido genetrix in limine visa est, abicit exceptamque avidis circumligat ulnis, iam gravis amplexu iamque aequus vertice matri.

Ach. 1.167-173

By chance he arrives cheerfully, too (oh, how much joy adds to one's form!): beneath a cliff of Pholoë he had struck down a lioness with iron, one which had newly given birth, and had left her in the empty hollow, but he carries back her cubs and arouses their claws. Yet these ones, when the mother is seen on the faithful threshold, he throws aside, and having taken her up, encircles her with his eager forearms, already strong in his embrace and already equal to his mother in height.

\footnotetext{
${ }^{35}$ Fantham (1999), 66.

${ }^{36}$ Upon seeing Deidamia: "eat atque ultro ferus hospita sacra / disiciat turbae securus et immemor aevi, / ni pudor et iunctae teneat reverentia matris." - Ach. 1.310-12 ("He would have gone forth and, willingly wild, scattered the foreign rituals, untroubled by the tumult and unmindful of his age, if shame and reverence for the mother beside him had not held him back.")

${ }^{37}$ Mendelsohn (1990), 299-301.

${ }^{38}$ Achilles himself recalls this action (or something similar) to Ulysses and Diomedes at Ach. 2.125. Heslin $(2005,190)$ notes another interesting parallel between this passage and an Ovidian simile comparing Hecuba's rage at seeing the dead Polydorus to a lioness whose cub has been stolen (Met. 13.545-552). While Heslin states that this is testament to Achilles' courage (the Ovidian passage represents "the proverbial fierceness of nursing lionesses"), it also foreshadows Achilles' actions at Troy. While he is not responsible for the death of Polydorus, he will have a part in the deaths of Hector, Troilus and Polyxena, stealing away some of Hecuba's other 'cubs' just as he has with this lioness.
} 
Quite plausibly, Mendelsohn argues that this passage is ambiguous, as it is initially unclear whether "genetrix" in line 171 is intended to refer to Thetis or the lioness. Statius' use of the passive "visa est" instead of the active "vidit" adds to this confusion by making it unclear whom the genetrix is seen by. ${ }^{39}$ Where the active would have required either singular or plural (Achilles or the cubs), the use of the passive removes this clarity. As the catuli have most recently been mentioned, Mendelsohn suggests that the audience are initially coaxed into believing that "genetrix" refers to the lioness, as if Statius describes the cubs seeing their mother left lying in the threshold of their cave as Achilles carries them off. Although this ambiguity is broken in the following line when Achilles throws down his cubs and it becomes apparent that "genetrix" refers to Thetis, the ambiguity that has been created remains a subtext to the passage, encouraging the association of Thetis with the lioness - it is almost as if Achilles has killed his mother.

If Thetis may be associated with the lioness, Statius then implies the association of Achilles with one of the cubs whose claws he incites. And this is not so great a stretch - Mendelsohn notes that the word unguis is often connected with youth. ${ }^{40}$ Moreover, the 'cub' parallel occurs again at Ach. 1.858, when Achilles loses himself to the thought of war upon seeing the shield, and betrays his feminine disguise:

ut leo, materno cum raptus ab ubere mores accepit pectique iubas hominemque vereri edidicit nullasque rapi nisi iussus in iras, si semel adverso radiavit lumine ferrum, eiurata fides domitorque inimicus, in illum prima fames, timidoque pudet servisse magistro.

Ach. $1.858-863$

Just as a lion when, having been taken from his mother's teats, he has accepted habits and has been taught to have his mane combed and to respect people, and not to get carried away in anger unless he has been ordered, if on one occasion iron shines a hostile glint, having rejected his faithfulness and become hostile to his tamer, his first hunger is against that man, and he is ashamed to have served a cowardly master.

Aside from the innate savagery and refusal to follow mores that this passage highlights (which will be addressed in the next sections of this chapter), it is worth considering that the young lion to whom Achilles is compared here has, like the cubs, been stolen

\footnotetext{
${ }^{39}$ Mendelsohn (1990), 300-301.

${ }^{40} \mathrm{Cf}$. "a teneris unguiculis", Cicero's Ad Fam. 1.6.2, and "de tenero ungui", Horace's Carm. 3.6.24 - note as well that in the Achilleid, Achilles' youth is referred to as "teneris annis" at 2.96 , and "tenues annos" at 1.148 , preceding this passage.
} 
away from its mother in his youth. Another parallel can be made with Catullus' Ariadne, abandoned by Theseus, when she cries "quaenam te genuit sola sub rupe leaena?" ("What lioness bore you, beneath some lonely rock?" Cat. 64.154). ${ }^{41}$ Some of the connections between Theseus and Achilles have already been noted, ${ }^{42}$ and in this context the similarities between this line and the "sub rupe leaenam" at Ach. 1.168 (as well as "genuit" and the "genetrix" at Ach. 1.171) heavily imply that like Theseus, Achilles has also been born to a 'lioness', with all the vicious heartlessness which that entails.

Thetis herself also becomes particularly problematic as a result of her 'maternal anxiety' for Achilles. ${ }^{43}$ She relates to Chiron a series of terrible, though fictitious, dreams, that foreshadow Achilles' fate and portray the mother and son as though they are at odds with each other:

"namque modo infensos utero mihi contuor enses,
nunc planctu livere manus, modo in ubera saevas
ire feras; saepe ipsa - nefas! - sub inania natum
Tartara et ad Stygios iterum fero mergere fontes."

Ach. 1.131-134

"For now I am seeing swords enraged against my womb, now my hands are discoloured by my mourning, now savage beasts attack my breasts; often I myself am even bearing my son down to the empty underworld - an unspeakable thing! - to immerse him again in the Stygian springs."

While Thetis' excuse is certainly fictional ("sic ficta parens" Ach. 1.141), it is not unreasonable to assume that it is a fiction that is influenced by her very genuine fear for Achilles. The implications of her fictional dreams are certainly very real; her womb and breasts, or metonymically, the product of her womb and breasts, is in danger - that is, Achilles. ${ }^{44}$ Her hands, bruised by beating her breasts, foreshadow the fate of Achilles that she is trying so hard to avoid. As Mendelsohn argues, "in Thetis' mind Achilles' death signifies radical violence to her own person" 45 - radical violence that is justified (to some degree) as the self-harm involved in appropriately mourning

\footnotetext{
${ }^{41}$ Mendelsohn (1990), 300, n. 20. Cf. also Dido to Aeneas at Aen. 4.365-67.

${ }^{42}$ And will be noted further in the following chapters. Theseus is linked in particular via Catullus 64 - the verbal parallel most often cited (e.g. by Hinds (1998), 125-29, and Davis (2006), 139) is between "irrita ventosae rapiebant verba procellae" (Ach. 1.960), and "irrita ventosae linquens promissa procellae" (Cat. 64.59 - cf. also 64.142 and 64.164-66).

${ }^{43}$ Mendelsohn (1990), 296.

${ }^{44}$ As Heslin (2005), 190, notes, Thetis never suckled Achilles (cf. Ach. 2.98-102), but this point is no serious impediment to the suggestion that her breasts are symbolic of her motherhood.

${ }^{45}$ Mendelsohn (1990), 299.
} 
for a loved one. The suggestion that she might immerse Achilles in the Styx a second time foreshadows the claim at Ach. 1.269-70 that she regrets not immersing him completely the first time ("totumque utinam!"), and quite innocently implies that she might attempt to avoid Achilles' fate by immersing him again. However, in the context of a passage that foreshadows Achilles' death, the description of Thetis bearing him down to the underworld - an underworld described as nefas! - certainly does not feel like a measure to spare his life. In addition, while "ipsa" may agree with either Thetis or "inania Tartara", modern translators tend to understand it in reference to Thetis. ${ }^{46}$ This interpretation implies that like the beasts and swords that were just attacking Thetis' body/Achilles, she herself is now the agent of his destruction. ${ }^{47}$

In some ways, Thetis is this agent of destruction. The reason she gives for taking Achilles away from Chiron is that she must purify him in "secret straits" ("secretis fretis", Ach. 1.137) at the ends of the earth (perhaps interpretable as the Styx in her dream). ${ }^{48}$ In his note on these lines, O. A. W. Dilke clearly demonstrates that her language recalls that of Dido deceiving Anna into placing all the items in her home connected to Aeneas onto a pyre at Aen. 5.480ff. ${ }^{49}$ While each woman is successful in her deception, Dido's actions lead to her death, which may imply a similarly unfortunate end in Thetis' case. ${ }^{50}$ Of course, neither Thetis nor Achilles actually dies as a result of his transvestism, but that transvestism does represent a symbolic death for Achilles. Aside from Ach. 1.157, above, Statius only mentions the Styx three times. ${ }^{51}$ The first two occurrences, as in this passage, describe Achilles' Stygian bath as an infant. The final mention of the Styx, however, is in his monologue on Scyros, before his rape of Deidamia, where he imagines that Sperchius has given up all hope

\footnotetext{
${ }^{46}$ Thus Meheust in the Budé of 1971, Shackleton Bailey in the Loeb of 2003, and Hall, Ritchie and Edwards in the Cambridge Scholars edition of 2007. Dilke argues otherwise in his note ad loc. ("ipsa agrees with Tartara"), while Mozley (Loeb of 1928) neglects to translate it at all. ${ }^{47}$ Similarly, the sibilance and assonance in "saevas / ire feras; saepe ipsa - nefas!" bridges any gap between the two phrases. Note that if Thetis' breasts and womb represent Achilles (in that violence done to her foreshadows his fate), self-harm of those breasts becomes metaphorical harm of Achilles.

${ }^{48}$ Heslin (2005), 116-17.

${ }^{49}$ Dilke (1954), 95.

${ }^{50}$ Heslin (2005), 117.

${ }^{51} 1.269,480$, and 630.
} 
of his return, and he is believed to be dead. His description of Chiron's mourning here may be intended to recall Thetis' mourning at Ach. $1.132:^{.52}$

“...quaerisne meos, Sperchie, natatus

promissasque comas? an desertoris alumni nullos honos, Stygiasque procul iam raptus ad umbras dicor, et orbatus plangit mea funera Chiron?

Ach. $1.628-631$

"Do you, Sperchius, seek my swims, and long hair? Or do you have no honours for your nursling deserter, and am I already said to have been carried far off to the Stygian shadows, and does Chiron, deprived of me, already mourn my death?"

The association of Achilles' transvestism and death does hold true, in a sense - as long as Achilles is believed to be his own sister, as far as others are concerned Achilles himself is no longer alive, as if Thetis has killed him, just as he killed the lioness, who serves as a symbol his own mother.

Thetis' description of her dreams also alludes to the relationship between Theseus and Ariadne. Her claim "modo in ubera saevas / ire feras" ("now savage beasts attack my breasts", Ach. 1.132-3) not only recalls the lioness Achilles killed, but also mirrors Ariadne at Cat. 64.152-33. Imagining herself as the prey of wild beasts in a similar way, Ariadne gives the impression that Theseus himself (as a wild beast born to a lioness, cf. Cat. 64.154 above) is tearing her apart ("dilaceranda feris dabor alitibusque / praeda" - "I will be given as a prize to beasts and birds, to be torn into pieces", Cat. 64.152-3). Within the Achilleid, Mendelsohn and Heslin understand the presence of these saevae ferae in Thetis' dream (in which they attack her ubera"breasts" or even "teats", Ach. 1.132) as an allusion to the cubs of the lioness Achilles killed at Ach. 168-70. ${ }^{53}$ Moreover, the lioness had just given birth to these cubs ("fetam", Ach. 1.168) presumably suckling them before she was killed by Achilles. With Thetis understood to be the lioness, Achilles himself can be understood as one of the cubs, but from this perspective he also becomes one of the saevae ferae that attack his mother's breasts in her dream (although - or perhaps partly because - he was

\footnotetext{
${ }^{52}$ Note also that when Achilles leaves Chiron, Thessaly laments his fate - "illum non alias rediturum ad Thessala Tempe / iam tristis Pholoë, iam nubilus ingemit Othrys" ("That one, who would not return to Thessalian Tempe at another time, already sorrowful Pholoë, already cloudy Othrys sigh over..." - Ach. 1.237-8) This premature mourning is in a similar vein as Chiron's laments in that it connects Achilles' transvestism with death, but in this case it is also foreshadows Achilles' actual death.

${ }^{53}$ Mendelsohn (1990) 301, Heslin (2005), 190.
} 
never breast-fed by Thetis). Moreover, the ferrum with which he slays the lioness recalls the infensos enses that attack her womb.

In this way, Achilles' first appearance in the epic (prefaced by Chiron's description of his transgressive 'horse-play') is undercut by the violent subtext to his happy reunion with Thetis; she imagines bearing her son down to the underworld, and Achilles kills a lioness that may be understood to represent her. The formidable potential for brutality that is inherent in Achilles' actions - just as in his youthful 'play-fights' with the centaurs - prefigures him as one of the problematic heroes he so badly wants to emulate; like Hercules in Seneca's Hercules Furens (or even that of Euripides'), he is a danger not just to his society, but to his own family.

\section{$\underline{\text { Achilles as Apollo }}$}

Despite the deep cracks in Achilles' filial relationship, it was noted earlier in this chapter that Chiron's educative role in the Achilleid is to tame this transgressive side; i.e., to teach him how to restrain his more animalistic tendencies and behave in a civilised manner. ${ }^{54}$ In this capacity Chiron is understood as the archetypal teacher for young heroes. His unique tutelage (mirrored by his physiology) provides an opportunity for reconciliation between the two fundamental aspects of a Homeric education; he is capable of teaching violent deeds, but also how to act appropriately and to manage those deeds in conjunction with the nomoi of one's society. Cameron notes that he is traditionally not only responsible for the education of Achilles, but also for that of Jason, Theseus, Peleus, and at least eighteen others. ${ }^{55}$ Statius does not explicitly state in the Achilleid that Chiron has tutored anyone other than Achilles, but he alludes to these other famous students at Ach. 1.157, when Chiron compares Achilles to "iuvenem Alciden et Thesea" ("a young Alcides and Theseus").

\footnotetext{
${ }^{54}$ Fantham (1999), 63.

${ }^{55}$ Cameron (2009), 18. The eighteen other names that he lists are those presented in Xenophon's Kynegetikos, which describes Chiron receiving the gift of hunting from Artemis

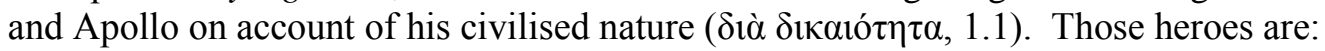
Cephalus, Asclepius, Milanion, Nestor, Amphiaraus, Telamon, Meleager, Theseus, Hippolytus, Palamedes, Odysseus, Menestheus, Diomedes, Castor, Polydeuces, Machaon, Podalirius, Antilochus, and Aeneas.
} 
In line with this tradition, extant art work and literature

demonstrates a strong Roman affinity for the topos of Chiron teaching Achilles to play the lyre, as can be seen in the image from Herculaneum, to the right. ${ }^{56}$ As mentioned earlier in this chapter, Cameron cites no fewer than seven extant wall paintings from Pompeii alone that show Chiron teaching Achilles the lyre, and as

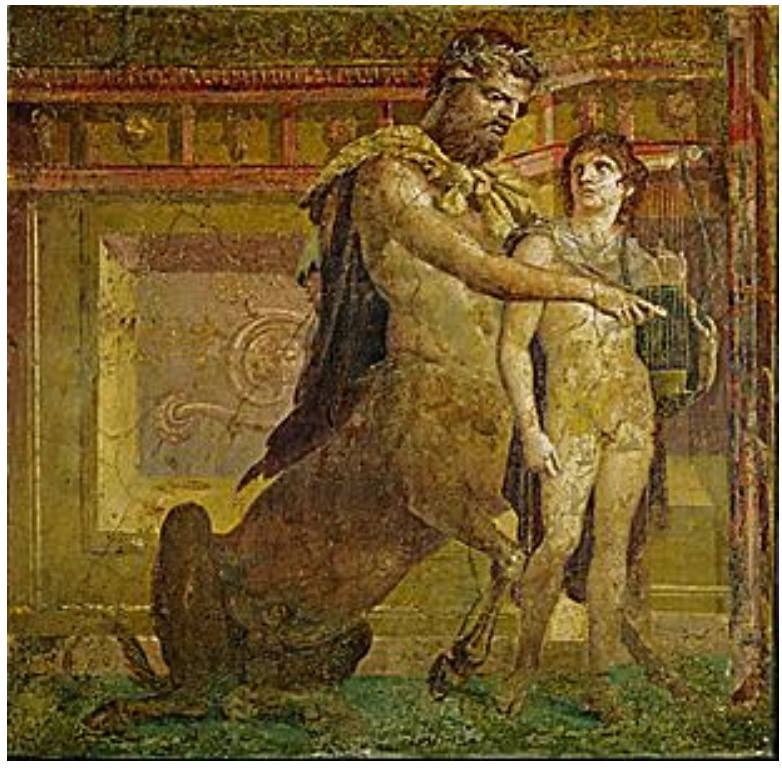
many instances from literature before or contemporary with Statius. ${ }^{57}$ One of these is in the proem of Ovid's Ars Amatoria, an elegiac guide to seduction which Lorenzo Sanna has already demonstrated is a strong intertext for the Achilleid. ${ }^{58}$ Ovid claims that he will use poetry to calm the boy-god "Amor" ("Love"), just as Chiron did with Achilles:

ille quidem ferus est et qui mihi saepe repugnet: sed puer est, aetas mollis et apta regi.

Phillyrides puerum cithara perfecit Achillem, atque animos placida contudit arte feros...

A.A. $1.9-12$

Indeed, [Amor] is savage, and one who would often oppose me: but he is a boy, an age that is soft and suitable to be ruled. The son of Philyra (Chiron) completed the boy Achilles with a lyre, and quelled his wild spirit with the peaceful art...

Perhaps with this image in mind, Statius compares Achilles returning from the hunt to Apollo laying down his dangerous quiver in favour of a musical quill. The parallels between the two figures are strong, both being youthful, idealised, and well educated, but with a more dangerous potential: ${ }^{59}$

niveo natat ignis in ore purpureus fulvoque nitet coma gratior auro. necdum prima nova lanugine vertitur aetas, tranquillaeque faces oculis et plurima vultu mater inest: qualis Lycia venator Apollo cum redit et saevis permutat plectra pharetris

Ach. 1.161-66

\footnotetext{
${ }^{56}$ This image was scanned from Feder (1978), 83.

${ }^{57}$ Cameron (2009), 10-11. See also Trimble (2002).

${ }^{58}$ Sanna (2007).

${ }^{59}$ Cf. Rabel (1990) for an analysis of Achilles as Apollo in the Iliad.
} 
A purple flame swims in his snowy face and his hair shines more pleasingly than yellow gold. Not yet is his first youth changed by new down, the fires of his eyes are tranquil, and there is much of his mother in his face: just as the Lycian hunter, Apollo, when he returns and exchanges his savage quiver for a quill.

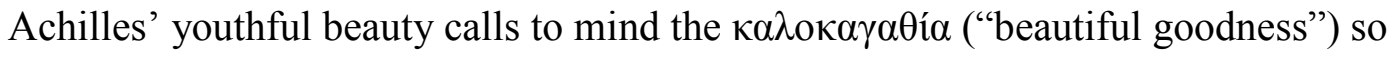
idealised in the Classical era, but the simile is not just empty praise - Achilles does take up the lyre, and does sing of the deeds of previous heroes down to his parents' own wedding. Even when he is wearing women's clothing, he is shown teaching Deidamia to play the lyre (Ach. 1.572-79), and she also sings about him ("et praesentem cantat Achillem" - "and she sings about Achilles, [though he is] present", Ach. 1.579). Statius associates this aspect of Achilles' education with his fate as a hero of epic poetry, building a cultured youth who is as much a poet as he is a warrior.

Nevertheless, in contrast Ovid's depiction of Achilles at A.A. 1.12 maintains an innate savagery (feri animi), which Chiron was able to tame (contundere - more often "to crush" or "to subdue completely") by teaching him music. The motif of wildness being tamed is pursued in the lines following, applied to Amor as well as to Achilles:

Aeacidae Chiron, ego sum praeceptor Amoris: saevus uterque puer, natus uterque dea. sed tamen et tauri cervix oneratur aratro, frenaque magnanimi dente teruntur equi;

A.A. $1.17-20$

As Chiron was to Aeacides, thus I am the teacher of Love: each is a ferocious boy, each the son of a goddess. But nevertheless even the neck of a bull is burdened with a plough, and a bridle is worn away by the teeth of a great-spirited horse.

In the Achilleid, however, the 'taming' of Achilles' bestial side is far less convincing. Statius manipulates this Ovidian passage again at 1.277-82, after Achilles has left his childhood education under Chiron, comparing the young hero to a horse (who in the Ovidian version was magnanimus, just as Achilles is magnanimus in Ach. 1.1). Achilles, who has not been tamed by his time with Chiron, refuses the transvestism proposed by his mother just as the young, untamed horse refuses his first bridle:

effrenae tumidum velut igne iuventae si quis equum primis submittere temptet habenis: ille diu campis fluviisque et honore superbo gavisus non colla iugo non aspera praebet ora lupis dominique fremit captivus inire imperia atque alios miratur discere cursus.

Ach. 1.277-82

Just as if somebody were to try to subdue a horse, puffed up with the fire of an unbridled youth, to his first reins: having long rejoiced in 
the fields and rivers and with a proud dignity, he neither submits his neck to the yoke nor his mouth to the bit, and he neighs [his refusal] to become prisoner to the commands of his master, and seems bewildered to learn other pursuits.

While this refusal to don women's clothing may be construed as appropriate to Achilles' heroic stature, the intertextual reminiscences nevertheless make it clear that no amount of music in his time with Chiron has 'tamed' his wild behaviour.

Moreover, when Achilles sees Deidamia shortly after this passage, he is compared to a bull seeing a heifer and foaming at the mouth (Ach. 1.313-17); he is not burdened with a civilising plough or bridle.

As the final section of this chapter will show, these animalistic comparisons are not uncommon in the Achilleid. The language of wild beasts that Ovid uses in the Ars is strewn throughout the text, and regularly associated with Achilles - despite being raised by Chiron, he is still saevus ("savage" or "ferocious") and ferus ("wild"). And if transvestism is the frena of the Achilleid that restrains Achilles' animalistic tendencies (though a 'bridle' that is thrown off as soon as the feminine clothes are removed, as will be shown), the teachings of Statius' Chiron have certainly not had the taming effect which are ascribed to them in the Ovidian tradition.

\section{$\underline{\text { Saevus Achilles }}$}

Although Achilles is called ferus only twice in the Achilleid (at Ach. 1.310 and 852) and the epithet saevus is never directly applied to him, the text nevertheless creates an impression of a saevus Achilles. The words are often connected with him in some way, whether his weapons are saeva or he is fighting others who are feri. As noted above, Achilles is represented in Thetis' dream as the product of her body, attacked by saevae ferae, yet paradoxically he is also one of the saevae ferae themselves. Achilles' wild, animalistic nature is a key theme of the epic, particularly during his education under Chiron.

Despite the rarity of ferus and saevus as epithets in the Achilleid, there is something of a tradition of a saevus Achilles in previous Latin literature. Thus saevus is applied to Achilles at Aen. 2.29 ("hic saevus tendebat Achilles" - "this place savage Achilles held") and in Ovid's Metamorphoses - at 12.582 ("saevumque... Achillem"), and eleven lines later, Poseidon complains that he is ferocious: "ille ferox belloque cruentior ipso / vivit adhuc" ("that man, ferocious and more cruel than war itself, still 
lives!" 12.593-4). As if this were not enough, at 13.504-5, after the shade of Achilles has demanded that Polyxena be sacrificed to him, Hecuba complains that he still destroys the Trojans even after death: "cinis ipse sepulti / in genus hoc saevit" ("the very ashes of his grave rage (or "are savage”) against this (our) race!”). In a particularly memorable case, Ovid uses the word to describe Eurytus, the centaur whom Nestor claims initiated the centauromachy by seizing Hippodameia, as "most savage of the savage centaurs": "saevorum saevissime Centaurorum, Euryte!" (Met. 12.219) As the first section of this chapter argued, Statius connects Achilles as much with the centaurs of Ovid's centauromachy as with the Lapiths (or indeed, Ovid's Achilles himself), and thus it is not unreasonable to expect something of their savagery to be applied to Achilles in the Achilleid. If Statius' literary tradition does in fact tendentiously privilege the Metamophoses as a primary intertextual model for the Achilleid, the presupposed framework of a saevus Achilles is rather strong. ${ }^{60}$

An excellent example of the way Statius indirectly depicts Achilles' wild nature in the Achilleid is in his description of the food he was fed as a baby at Ach. 2.98-102. The association of Achilles with the animals he eats or hunts is a topos that is often repeated in the Achilleid, and begins to construct a subtext of a savage and barbaric hunter-warrior beneath the poet-hero facade that is depicted more overtly. Thus he claims that he is said:

...non ullos ex more cibos hausisse nec almis uberibus satiasse famem, sed spissa leonum viscera semianimisque lupae traxisse medullas. haec mihi prima Ceres, haec laeti munera Bacchi, sic dabat ille pater.

Ach. 2.98-102

...to have swallowed no food of the usual custom, nor to have sated my hunger with nurturing teats, but to have taken the thick entrails of lions and the marrow of a half-dead she-wolf. These were the first bread for me, these the first gifts of joyous Bacchus, thus that father gave me.

The tradition in which Achilles ate raw meat as a baby is certainly present before Statius. ${ }^{61}$ Apollodorus states that after Peleus gave Achilles to Chiron, the centaur fed him on the entrails of lions, boars and bears:

\footnotetext{
${ }^{60}$ Cf. also Horace's Ars Poetica 119-122, discussed in the introduction to this chapter. ${ }^{61}$ In addition to Apollodorus' Bib. 3.13.6, it is worth noting a scholiast on Homer's Iliad, 16.37, and several artworks - discussed in more depth by D. S. Robertson (1940), Alan Cameron (2009), 9, and Heslin (2005), 173-75.
} 


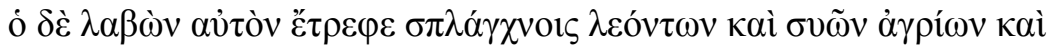

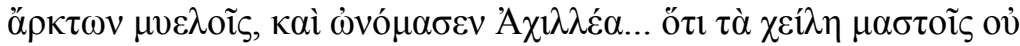
$\pi \rho \circ \tilde{v} v \varepsilon \gamma \kappa \varepsilon$.

Bib. 3.13.6

And taking [Achilles], [Chiron] reared him on the innards of lions and the marrow of wild boars and bears, and he named him Akhilleus... because he did not bring his lips to a breast. ${ }^{62}$

For J. G. Frazer, the consumption of these animals' raw innards was "no doubt supposed to impart to the youthful hero who partook of them the strength and courage of these animals." 63 The Achilleid takes this a step further, however; Heslin claims that "semianimis was meant to shock and disgust a Roman audience, for whom the eating of raw versus cooked meat marked the division between animal and human as much as or more than it does for us today." 64 In addition to these two arguments, the food of the ferus puer (or fera puella) in wider literature is perhaps worth considering.

The ferus puer/puella is a common literary trope, but in nearly every case the child is nurtured by animals - usually fed with their breast-milk of a new mother - and can become more like an animal as a result. For example, in the Bibliotheca Telephus is nurtured by a doe (3.9.1), and Atalanta and Paris are nurtured by bears -the former even learning to fight like a bear (3.9.2 and 3.12.5). Vergil's Camilla is nursed with the help of her father, but on the milk of a wild mare (Aen. 11.570-72), and Romulus and Remus, of course, are nearly invariably suckled by a she-wolf (cf. lupa feta in Ov. Fas. 2.413, and also the lupa in Livy 1.4.6). Even Enkidu in the epic of Gilgamesh, although he is not fed on the animals' milk, does co-exist peacefully with the animals around him. ${ }^{65}$ The tradition in which Achilles is not only reared without the milk of animals but actually eats animals raw is unique even in comparison to these other feral children. Yet in depicting a mammal who is paradoxically not suckled (and thus not, strictly speaking, a mammal at all), this background goes further than mere uniqueness or savagery, imparting to Achilles a tinge of monstrous abnormality that renders him neither human nor animal. ${ }^{66}$ The food of Achilles is not just non ex more ("not from

\footnotetext{
${ }^{62}$ Apollodorus claims that the etymology of his name is " $\alpha \dot{\alpha}-\chi \varepsilon \dot{\varepsilon} \lambda \eta$ ” (a-kheile), meaning "without-breast"). Etymologies for the name "Achilles' are discussed in more depth by Heslin (2005) 175-81.

${ }^{63}$ Frazer (1912), 138-168. Frazer also develops this motif in a range of other contexts, both mythical and historical.

${ }^{64}$ Heslin (2005), 174-5.

${ }^{65}$ Tablet 1 , column 2.

${ }^{66}$ And if Apollodorus' etymology for Achilles' name ( $\dot{\alpha}-\chi \varepsilon \dot{\imath} \lambda \eta$, discussed above) was plausible to his audience, this unnaturalness must be (to some degree) a defining feature of their perception of Achilles.
} 
the usual custom", Ach. 2.98) of civilised people, but even non ex more of barbaric people or animals.

The animals which he eats in the Achilleid - lions and a she-wolf - are also particularly interesting. To begin with, they are predators; just as the animals' halfalive state (semianimis lupa), mentioned above, may be intended to disgust a Roman audience ${ }^{67}$ this too emphasises his barbarity in contrast to the diet of civilised Rome. However, the animals themselves have wider symbolism. The two other appearances of lions as a part of Achilles' upbringing, at Ach. 1.168-70 (as above, a lioness associated with his mother) and at Ach. 2.125 (which recalls the same passage, also noted above), are both fetae leaenae (a lioness who has just given birth). If it is not unreasonable to thus associate the lions Achilles eats with fetae leaenae, there is a certain vindictiveness inherent in the image of the hero eating the raw entrails of these animals which could just as easily have nurtured him. In a similar way, the mention of a lupa (a she-wolf) - which is unique to Statius in the tradition of Achilles' peculiar food as a baby ${ }^{68}$ - in a Roman context undoubtedly calls to mind the lupa (feta) which suckled Romulus and Remus (cf. Ov. Fas. 2.413, and Livy 1.4.6, as above). The result of this casual inclusion of a she-wolf, therefore, is not just that Achilles is portrayed with the same fierceness and savagery as the predator he eats. Rather, he is depicted eating the same kind of animal that will nurture the other wild children who go on to found Rome itself; a rather more problematic image for Statius' Flavian audience. $^{69}$

Achilles' savage nature is also stressed in other aspects of his education. The Achilleid's several mentions of his hunting ${ }^{70}$ like the image of him eating wild animals, stress the wildness that is inherent in hunting and killing over and above the element of a civilised human triumphing over the wildness of the ferae. Thus he talks about the loneliness of the forests in his description of his childhood for Ulysses and Diomedes, particularly when he asks "quid nunc tibi proelia dicam / silvarum et saevo vacuos iam murmure saltus?" ("What good would it be now for me to tell you of the

\footnotetext{
${ }^{67}$ Heslin (2005), 174.

${ }^{68}$ Cf. D. S. Robertson (1940), 177.

${ }^{69}$ Barchiesi (1996), 55, also notes this: "qui Stazio supera ogni modello conosciuto" ("here Statius surpasses every known model"). The Rom(ul)an descent from Trojan Aeneas may also be relevant here, as a promise of the destruction that Achilles will wreak on Troy and its descendants - cf. the saevus Achilles of Aen. 2.29.

${ }^{70}$ Ach. 1.167-70, 1.626-27, 2.102-5, 2.119-128, and perhaps also Ach. 1.358
} 
battles of the woods and the glades now empty of savage murmuring?" Ach. 2.119-20). As with Thetis' dream and Achilles' return from the hunt, there is a degree of ambiguity in the application of "saevo... murmure". Dilke takes the safe road, arguing that "it probably applies to wild animals rather than... to Achilles' shouts."

Nevertheless, J. H. Mozley and Jean Meheust choose to apply the phrase to Achilles thus "my fierce shout" and "mon cri féroce". ${ }^{72}$ Hall, Ritchie, and Edwards, along with Shackleton Bailey, choose to maintain the ambiguity of the Latin. ${ }^{73}$ And as with "genetrix" at 1.171 , the ambiguity of this passage is particularly effective. While "murmure" may be more safely applied to the animals Achilles has killed rather than Achilles himself, the phrase's lack of clarity causes something of the savagery of the animals he goes on to describe (bears, boars, tigers, and lionesses) to be apportioned to him.

Similarly, there is little focus on prey animals, as killing a more dangerous animal imparts greater fama $^{74}$ and provides a stronger test for Achilles. Nevertheless, killing animals that are inedible (at least to most people) distances his behaviour from the more typical hunting of game animals for food, and connects his actions with violent warfare. For example, in Achilles' monologue he lists hunting and warfare together as central features of masculine youth that are lost through transvestism, asking himself:

\footnotetext{
"Quonam timidae commenta parentis usque feres, primumque imbelli carcere perdes florem animi? non tela licet Mavortia dextra, non trepidas agitare feras?"
}

Ach. $1.624-627$

"How long will you endure the schemes of your timid mother, and waste the first flourishing of your youth in an unwarlike prison? Is it not permitted for your hand to bear the spears of Mars, nor for you to stir up frightened beasts?"

\footnotetext{
${ }^{71}$ Dilke (1954), 149.

${ }^{72}$ Loeb of 1928 and Budé of 1971 respectively.

${ }^{73}$ Loeb of 2003 and Cambridge Scholars of 2007 respectively. Examining other uses of murmur in Statius' work seems of little use - as Dilke (who prefers to think it refers to the beasts) notes, it is used regularly, and applied to the sounds made by all manner of people, beasts, and inanimate objects. The other two occurrences of the word in the Achilleid refer to people (1.380 and 1.554), but this certainly does not mean "murmure" does not refer to beasts in this case - especially as it agrees with "saevo", and is used in the context of hunting in the woods.

${ }^{74}$ I have generally used fama because the Achilleid is a Latin epic, but the Greek 'kleos' would also be suitable; Statius' Achilles' preoccupation with his reputation is easily tied into the Iliad.
} 
The description of the beasts Achilles hunts as "trepidas" is certainly not in line with the way he describes them at other points in the Achilleid, however - unless trepidus is understood to mean 'perilous', rather than the more typical 'frightened' or 'fearful'. At Ach. 2.121-3, he describes the animals Chiron allowed him to hunt, but those animals he is permitted to hunt are the ones who are not trepidae (in the 'fearful' sense), nor timidae, nor inbelles: $:^{75}$

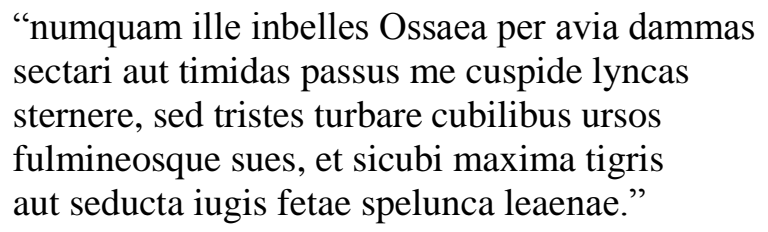

Ach. 2.121-125

"Never would [Chiron] allow me to pursue unwarlike does through the wilderness of Ossa, or to strike timid lynxes with my spear, but to disturb gloomy bears in their lairs and destructive boars, or the biggest tigress, wherever she was, or the secluded cave of a lioness with new cubs on a mountain."

The similarities of subject and vocabulary between this passage and his monologue (hunting imagery of stirring up wild animals with a spear, and "imbelli"/"imbelles" alongside "timidae"/"timidas") encourage the conflation of transvestism and Thetis with other 'timid' and 'unwarlike' things that Chiron did not permit him to do. Thus Achilles depicts his departure from obedient transvestism as an embrace of his wild education under Chiron at the expense of Thetis' schemes. ${ }^{76}$ However, these parallels also imply that the beasts he hunts are not "trepidas" because they are timid or unwarlike in some way, but because (despite being dangerous) they are terrified of him - a sentiment that is recalled again when he states that while he was still young Chiron taught him "arridere feris nec fracta ruentibus undis / saxa nec ad vastae trepidare silentia silvae.” (“...to laugh at wild beasts, and to fear neither rocks shattered by rushing waves nor the silences of a huge forest." Ach. 2.103-4). In each of these cases, Achilles' hunting is not a mark of civilisation overcoming the natural world or of learning to provide for himself; rather he describes his hunting as "agitare", "sectari", "sternere", and "turbare" (to "stir up", "pursue", "strike", and

\footnotetext{
${ }^{75}$ Interestingly, with the exception of the tigris the animals he hunts here are mostly the same savage beasts he eats in Apollodorus' description of his infancy.

${ }^{76} \mathrm{~A}$ depiction that is somewhat problematic in itself, as Achilles uses this monologue to convince himself to rape Deidamia, and then returns to his transvestism - not at all in line with what Chiron has supposedly been teaching him!
} 
"disturb"), and in each case the exercise is connected with war, or simply aims to make him more fearless and ferocious than the animals he attacks. ${ }^{77}$

Like hunting, war is also given an animalistic ferocity in the Achilleid, described not only as saevus but also ferus, a word used substantively to refer to wild beasts. $^{78}$ At 2.130-1, immediately after describing the beasts he hunted at Chiron's behest, Achilles describes learning about war by fighting with the nearby tribes, claiming: "nec me ulla feri Mavortis imago / praeteriit." ("and no aspect of untamed Mars (i.e., war) passed over me.”). Statius describes the preparations for war using similar language at 1.425: "ereptum superis Mars efferat aurum." ("Mars made savage gold that had been torn from the gods.") Even Achilles himself is called ferus Aeacides when he sees the weapons Ulysses has brought, and he rejects transvestism: at ferus Aeacides, radiantem ut comminus orbem caelatum pugnas - saevis et forte rubebat bellorum maculis - acclinem conspicit hastae, infremuit torsitque genas...

Ach. $1.852-855$

But the wild Aeacid, as he gazed at the shining shield inclined on the spear nearby, engraved with battles - and by chance it was red with the savage stains of wars - roared and rolled his eyes...

The animalistic language of this passage continues with saevis and "infremuit torsitque genas", making Achilles seem completely incapable of rational agency - a beast that is only temporarily restrained by music or transvestism.

Statius continues this connection to animals immediately following this passage, comparing him (again) to a half-tamed lion:

ut leo, materno cum raptus ab ubere mores accepit pectique iubas hominemque vereri edidicit nullasque rapi nisi iussus in iras, si semel adverso radiavit lumine ferrum, eiurata fides domitorque inimicus, in illum prima fames, timidoque pudet servisse magistro.

Ach. $1.858-863$

As a lion, when taken from the teat of its mother, accepts the customs (mores) and learns to have his mane combed and to venerate men, and never, unless he has been ordered, be seized by anger, if on a single time, iron shines out with a hostile glint, he rejects his loyalty and his tamer becomes an enemy, his first hunger is for that man, and he is ashamed to have served a cowardly master.

\footnotetext{
${ }^{77}$ As Arico (1986), 2937, puts it when Achilles appears, tormenting the cubs, the hero has about him "di un certo selvaggio sadismo" ("a certain wild sadism").

${ }^{78}$ For saevus applied to war, see Ach. 1.853, below, and 1.659-60 (Deidamia's hypothetical saevo funere, or "cruel death").
} 
It is worth noting the parallels between this passage and Ach. 1.277-82, mentioned above, in which Achilles' initial reluctance to cross dress is compared to a young, untamed horse being subjected to his first bridle. Again, Achilles has paid attention to Chiron's lessons - he understands the nomoi or mores that he should be obedient to but he nevertheless refuses (or is unable) to obey them. He leaves the centaur just as he came into his care: bestial and untamed.

\section{$\underline{\text { Conclusion }}$}

Statius' depiction of Achilles' education under Chiron is just as ambiguous as the depiction of his transvestism. Taking the received Roman tradition in which the young hero is considered an appropriate model for a well-rounded masculine education, on the surface Statius presents a hero who is young, beautiful, and cultured - the spitting image of a young Apollo. While (like Apollo) he has a dangerous potential, it is only appropriate to a warrior who will prove himself as skilled in battle as he is on the lyre. Chiron himself, as the one civilised centaur, provides a perfect teacher - he is the archetype of balance between culture and savagery.

Nevertheless, just as Chiron is physically bestial as well as cultured, Achilles is given the same subtext of wild volatility that underpins his character in the Iliad. His relationship with his mother, so respectful and refined on the surface, is subverted by metaphors in which she seems to be the prey that he hunts, or he himself is a lion cub attacking her breasts. Similarly, his appropriate emulation of the Lapith heroes - his father's generation - becomes particularly problematic in light of his troubling actions. He does not defend his society against the chaotic centaurs, but seems to act like a centaur himself, aggressively attacking them, carrying off their cattle, and burning their homes. In this way, Chiron's model of a cultured education triumphing over a physiologically innate wild nature is not mirrored in Achilles, but juxtaposed with him; Achilles' transgressive nature is thrown into a sharp relief alongside the idealistic but not realistic - civilised centaur.

In the following chapter, I pursue this motif of a transgressive hero in more depth through an examination of Achilles' transvestism. It has already been shown that the beginning of his transvestism is presented as a domestication of his wild nature, and the end of his transvestism as a release of this savage side. The world of Scyros, like the women's clothing itself, imposes a number of new expectations on 
him, but like Chiron's cultural sophistication, these boundaries only serve to emphasise his problematic nature when they do not align with his behaviour. Achilles' transvestism may be more blatantly problematic, but within the restrictions it imposes behaviour that previously seemed appropriate now seems inappropriate. Of course, behaviour that previously seemed inappropriate is still emphasised as such. The only path left open to Achilles is one of transgression. 


\title{
Chapter Two: Layers of Transgression in Rape and Ritual; or, Rules are made to be broken.
}

\begin{abstract}
"There was a wall. It did not look important. It was built of uncut rocks roughly mortared. An adult could look right over it, and even a child could climb it. Where it crossed the roadway, instead of having a gate it degenerated into mere geometry, a line, an idea of boundary. But the idea was real. It was important. For seven generations there had been nothing in the world more important than that wall.

Like all walls it was ambiguous, two-faced. What was inside it and what was outside it depended upon which side of it you were on."
\end{abstract}

Ursula K. LeGuin, The Dispossessed: An Ambiguous Utopia

The first chapter has demonstrated that the Achilleid's use of transgression is not limited to the obvious - Achilles' transvestism and rape of Deidamia. This chapter will build on that argument by addressing the ambiguities that Statius constructs even in such blatant transgressions as transvestism and rape. Ursula LeGuin's passage (above) nicely highlights different perspectives on the role of a literal wall, but it could just as easily be used metaphorically to describe many of the moral boundaries (mores) in the Achilleid. Just like the path of refined masculinity that Chiron sets out for Achilles, Thetis also constructs a life for her son which confuses the boundaries of appropriate action by normalising his transvestism in line with Statius' nomoi for the Scyrian women. ${ }^{1}$ Looked at from Thetis' perspective, Achilles' greatest transgression is not so much his donning women's clothing (which she might not normally approve of, but in this case she considers a safe path and a favour to her) but his violation of the Bacchic festival through the rape of Deidamia. On the other hand, rape is much less transgressive when looked at within an epic framework, ${ }^{2}$ but transvestism is in

\footnotetext{
${ }^{1}$ The use of nomoi as well as mores here (and throughout this thesis) is appropriate to the bicultural context of the epic. While mores (as expectations of a vir) is generally a better word to describe the moral imperatives and boundaries of appropriate behaviour that apply to Achilles in the Achilleid, Statius' Scyrian civilisation has its own rules and customs that are not necessarily consistent with Roman mores. I use nomoi to describe these. For example, the Bacchic revelry of Statius' Scyrian civilisation is clearly integral to their religion and in accordance with their nomoi, but may potentially be considered problematic from the standpoint of post-Bacchanalian Roman mores.

${ }^{2}$ And especially a Latin epic framework. Rape plays an important part in the Roman cultural consciousness such that it is not necessarily positive in and of itself, but is often associated with its positive results - thus, for example, the rapes of Ilia, the Sabine women, and even Lucretia. The same is true of Latin comedy, which will be discussed in more depth below. Nevertheless, the Achilleid does highlight and problematise the rape of Deidamia to some degree. The problematic elements will be discussed in more depth, but it is worth noting that the rape occurs "densa noctis... in umbra," (Ach. 1.640) and the moon shows her disapproval at Ach. 1.644: "et tenerae rubuerunt conua Lunae."
} 
some ways the ultimate rejection of the mores and masculine ideal presented by Chiron.

These two perspectives are not mutually exclusive, and in fact are complementary. There is an awareness from each perspective that transvestism and rape both exceed or contravene the boundaries of what would normally be considered socially appropriate behaviour by the Archaic Scyrian community; the difference is in which action is felt to be merely excessive and which is considered more clearly transgressive. Nevertheless, each perspective imposes restrictions on Achilles and encourages him to act within (different) socially approved frameworks. By way of comparison, both of these sets of mores are inconsistent with the role of boundaries in the Iliad, where Achilles' heroic greatness is demonstrated precisely by means of his ability - and inclination - to act outside of a socially approved framework if it suits him.

The emphasis I have placed upon Achilles' transvestism, rape, and violation of ritual is deliberate. These actions are not only his most clearly problematic actions, but also form the climax of the first book and signal a significant development (although somewhat protracted) in the plot of the Achilleid as we have it. The passages dealing with these themes are laced with intertextual parallels which colour an audience's reception of these events and have significant implications for interpreting the rest of the epic. To be more specific, allusions to certain literary treatments of tropes and mythological figures create precedents for Achilles' heroic transgression and transvestism that both normalise and problematise his actions for an educated Flavian audience.

Within this chapter, these allusions, tropes and mythological models will be discussed. Firstly, I will briefly address Achilles' 'metamorphosis' into a woman at the hands of Thetis, and the way in which Statius' similes treat him as though he is one of the Scyrian maidens. Achilles' assimilation into the band of women enables an educated audience to read their qualities and behaviours as also operating on the young hero. Thus a new set of expectations - of appropriate feminine behaviour - is imposed upon him. In this way, Thetis' transgressive act paradoxically appears intended to subdue Achilles' wildly transgressive nature. Nevertheless, her strict instructions to Lycomedes as she hands her son into the king's care foreshadow the upcoming rape, and are a reminder of the foreboding imagery of Chiron's upbringing. 
Statius' depiction of the band of Scyrian maidens (including Achilles) also foreshadows his transgression. Rather than simply being well-behaved young women as Thetis seems to expect, their chastity is associated with bacchants, amazons, and violent goddesses: paradigms of wild and dangerous virginity. Thus their attendance at the Bacchic festival is portrayed as dangerous and quasi-transgressive maenadism while simultaneously being considered pious and condoned by Scyrian society. The violent subtext provides an outlet for Achilles' innate volatility, which is realised by the rape of Deidamia, and a context which simultaneously problematises and normalises that rape on multiple levels.

The rape itself, and its ritual setting, is the subject of the third section. For this passage in particular, intertextual interpretations abound; Achilles' violation of the Bacchic ritual bears resemblances to tropes of elegy and New Comedy, Euripidean tragedy, Livy's description of Bacchanalian ritual at Rome, and even the historical transvestism of Clodius at the festival of the Bona Dea in 62 BCE. These models set precedents for the rape, but in a way that makes it even more problematic. The excessive violence and Deidamia's unwillingness are inappropriate to the models of elegy and New Comedy, whilst interpreting Statius' festival as an allusion to Euripides' Bakkhai sexualises the normally chaste Bacchic violence. Finally, the historical examples of Clodius and Livy's Bacchanalia actually make Achilles' actions seem more deviant, presenting serious issues for an audience in Flavian Rome, which Domitian intended to return to the moral principles of Augustus. ${ }^{3}$

Moreover, the parallels between the Scyrian maenadic ritual and Euripides' Bakkhai might seem to encourage the conflation of Achilles with Pentheus, but the behaviour of the two characters is markedly different during the ritual. Nevertheless, the arrival of Ulysses and Diomedes sees Achilles begin to act more like Pentheus, and Statius' negative depiction of the end of his transvestism foreshadows his fated death at Troy. Thus Achilles' demonstration of his heroic masculinity becomes a catalyst for his death, an inversion of epic norms that makes his transvestism and love for Deidamia seem appropriate and his embrace of heroism seem tragic and dangerous. In a sense, Achilles' true transgression against Bacchus' ritual is his failure to continue to transgress.

\footnotetext{
${ }^{3}$ Cf. Marks (2005), 209-88, for consideration of Domitian's moral aims and their impact upon Flavian literature (particularly with reference to Silius Italicus).
} 
The fourth section will consider one further model for this problematic passage: Hercules' heroic violation of the ritual of the Bona Dea in Propertius 4.9. Strong verbal allusions and the heroes' actions both in and outside of the passages encourage the association of these two ritual passages. In some ways this intertextual relationship is no less troublesome, encouraging conflation with Clodius and continuing Statius' forays into the elegiac genre. However, the parallels with 4.9 also give Achilles a new mythological model that contextualises his actions as the 'appropriate transgressions' of a truly great hero. ${ }^{4}$

\section{Achilles as Diana}

An extensive consideration of the dynamics of Flavian masculinity and effeminacy is well outside the scope of this work, but it is naturally relevant to the study of the Achilleid. As noted in the first chapter, Statius' construction of Chiron's educational program evokes an image of idealised classical masculinity which would not be out of place in the culture of the Iliad or in Roman imperial discourse. This paradigm is challenged, however, by Achilles' adoption of feminine clothing and performative gender. By its very nature, transvestism is a basic transgression that deconstructs or ignores the boundaries of socially approved behaviour for the agent's perceived gender, and it is particularly problematic in a Roman context, where gender roles are quite clearly defined. ${ }^{5}$

It is interesting, therefore, that even while encouraging Achilles to transgress by donning women's clothing, Thetis constructs new boundaries for his transvestite persona. Statius depicts Thetis' assistance with her son's adoption of transvestism as a moulding of his body as if he were a wax sculpture beneath her thumb (Ach. 1.32534). ${ }^{6}$ As part of this process of feminising Achilles, Thetis teaches him how to speak and walk as if he is a woman:

et picturato cohibens vestigia limbo incessum motumque docet fandique pudorem.

Ach. $1.330-31$

\footnotetext{
${ }^{4}$ I use the oxymoron 'appropriate transgression' advisedly. As outlined in the introduction, Achilles' transgressions actually increase the sense that he is heroic, providing a link to his Homeric character and drawing a stark contrast between him and a hero such as Aeneas (whose transgressions create greater difficulties for the argument that he is heroic). They are appropriate in this sense; that is, to Achilles' character and to his particular heroic nature.

${ }^{5}$ See Garber (1992) for a more in-depth discussion of transvestism as transgression.

${ }^{6} \mathrm{Cf}$. Heslin (2005), 145-55. This passage will also be discussed in the next chapter.
} 
And confining his footsteps with the decorated hem of his dress, she shows him how to walk and gesture, and be modest in his speech.

Achilles' adoption of feminine mannerisms may be necessary for his attempt to hide as a woman, but implies that rather than actually breaking down boundaries of gender, he has simply exchanged one set of approved behaviours for another set. Moreover, these new boundaries which Thetis uses to limit Achilles are metaphorically implied by her confinement of his footsteps within the hem (limbus - literally an edge or border, and thus also a boundary) of his dress. ${ }^{7}$

Achilles' new social boundaries are also reiterated in the following simile, comparing Achilles to Diana. Just as Latona softens the appearance of her wild daughter, Thetis softens Achilles' wild appearance to make him look more appropriately feminine - that is, to help him to conform to the role expected of a chaste maiden: ${ }^{8}$

sic ubi virgineis Hecate lassata Therapnis ad patrem fratremque redit, comes haeret eunti mater et ipsa umeros exsertaque bracchia velat; ipsa arcum phraetrasque levat vestemque latentem deducit sparsosque tumet conponere crines.

Ach. 1.344-8

Thus when Hecate returns wearily to her father and brother from maidenly Therapne, her mother clings to her as she walks, a companion, and she [Latona] covers her shoulders and exposed arms; she relieves her of bow and quivers and smoothes out the hidden garment and is proud to arrange her scattered hair.

This simile also provides a degree of continuity between Achilles' masculine and feminine personae. The simile above, comparing Achilles to Diana, provides an interesting counterpart to Ach $1.165-66$ (discussed in the previous chapter), in which Apollo (like Achilles) returns from the hunt and exchanges his savage (saevus) bow for the more peaceful lyre. ${ }^{9}$ Here too, Diana returns from wild activity and replaces her hunting weapons with a civilised, peaceful appearance. Statius' depiction of idealised masculine youthfulness is balanced by this parallel depiction of idealised

\footnotetext{
${ }^{7}$ Cf. also "tenui... discrimine" ("in a narrow distinction", Ach. 1.337) and "fine pudoris" ("with the boundary of modesty" 1.291) - the Achilleid's descriptions of gender and especially womanhood are replete with the vocabulary of boundaries and divisions.

${ }^{8}$ There are also a number of parallels between this passage and Artemis/Diana metaphors applied to Nausicaa at $O d .6 .102-9$ and Dido at Aen. 1.498-504, which help to associate Achilles with these beautiful heroic women.

${ }^{9}$ See Feeney $(2004,90-91)$, for another assessment of transgressive elements of the Diana simile. He argues that the parallels between this simile and the Apollo simile are "references to the male roles Achilles is abandoning, and to the deity he should 'really' be compared to, Apollo."
} 
feminine youthfulness, highlighting Achilles' ephebic and ambiguous appearance. ${ }^{10}$ The continuity between these similes helps to normalise the young hero's transvestism, and to convey the sense that he is now (at least in an external, public sense) female. Rather than anarchically breaking down the strict boundaries between masculine and feminine genders, Achiles assumes the feminine role wholeheartedly. His problematic transvestism has paradoxically become a force that encourages him to act within socially approved boundaries.

When Thetis has proudly tidied his appearance and made him look chaste and maidenly, this feminine Achilles is introduced to his new 'father', Lycomedes, as his own sister. Here, too, Thetis places limitations on Achilles' behaviour in accordance with his new gender role, giving the King careful instructions for what the 'maiden' should be allowed to do:

"Hanc tibi," ait, "nostri germanam, rector, Achillis - nonne vides ut torva genas aequandaque fratri? tradimus. arma umeris arcumque animosa petebat ferre et Amazonio conubia pellere ritu. sed mihi curarum satis est pro stirpe virili; haec calathos et sacra ferat, tu frange regendo indocilem sexuque tene, dum nubilis aetas solvendusque pudor; neve exercere protervas gymnadas aut lustris nemorum concede vagari. intus ale et similes inter seclude puellas; $\ldots$.

Ach. $1.350-59$

"This girl," she said, "the sister of our Achilles - do you not see how savage she looks in her eyes, and equal to her brother? - we hand over to you, ruler. She sought spiritedly to bear weapons and a bow upon her shoulder, and to banish marriage in the Amazonian tradition. But I have enough concerns for my male progeny; let this child bear the baskets and the sacred things, subdue her stubbornness with your guidance, and hold her within her sex, until she is at a marriageable age, and her modesty must be relaxed; and don't allow her to engage in lustful naked athletics, or to wander in the haunts of the woods. Raise her inside, and seclude her among similar girls.

Thetis' instructions transfer the transgressions of Achilles' masculine persona to his new feminine persona. As a youth he was too wild, assuming the role of the chaotic centaurs and savagely eating animals raw, and Thetis fears that as a maiden he will take on similar attributes, too wild for his new gender. Moreover, this wildness foreshadows his future transgressions: Thetis warns Lycomedes that Achilles' sister has been acting like an Amazon, and insists that the King not to allow her "lustris nemorum... vagari" ("to wander in the haunts of the woods"). Predictably, it is in the

${ }^{10}$ Cf. Feeney (2004), esp. 93-95. 
woods ("nemus" - Ach. 1.594) that Achilles begins to break free of these new feminine boundaries and rapes Deidamia. But as will be discussed in this chapter, the ambiguities in Thetis' request provide a loophole for his problematic nature; Achilles' new maidenly duty to "bear the sacred things" ("sacra ferat" Ach. 1.355 above) allows him access to the festival and the use of the phallic thyrsus, and thus appropriate feminine behaviour becomes an outlet to his transgression.

Finally, the passage above encourages the association of Achilles with the Scyrian maidens, a juxtaposition that has a strong bearing on the boundaries that are operative upon him in the Achilleid. Thetis' final request that Lycomedes raise Achilles among similar girls begins to build the premise that he is one of them - the focus of the epic and the depiction of Achilles shifts from the hero himself to the maidens as a group, and his feminine persona takes precedence. The following lines also encourage this conflation - the maidens take him under their wing in Ach. 1.36678, and as she leaves Scyros, Thetis offers up a prayer that cements Achilles' new role among the women: "sit virgo pii Lycomedis Achilles." ("Let Achilles be a maiden of pious Lycomedes." - Ach. 1.396) Nevertheless, this new role (with its new boundaries of appropriate feminine behaviour) does not come without its own problematic ambiguities and transgressions. Just as Achilles' wild masculinity is compromised somewhat by his ephebic appearance, so too the chastity of the Scyrian maidens is balanced by Statius' wild and violent depiction of them.

\section{Maenadic Maidens of Scyros}

Statius' use of pudor will be discussed further in the context of elegiac transgression in the following chapter, but the concept is a particularly important part of the construction of the Scyrian maidens, emphasising their modesty and chastity: the boundaries of appropriate feminine behaviour. The women are not so simplistic that this is their only attribute, however, and like Achilles, their complexity makes them problematic. As one might expect based on the depiction of Achilles as Diana or an Amazon, rather than being quiet and obedient "Lucretias", their modesty is modelled after a more violent form of virginal chastity.

The first appearance of the maidens in particular reveals the thematic trope that they follow in the epic. At a festival of Pallas, Deidamia leads the small "troop" of her 
sisters ("ducentem ... socia agmina" - Ach. 1.301), ${ }^{11}$ and is compared to Diana outshining the Naiads. ${ }^{12}$ Moreover, Statius states she is the equal of Pallas herself: ${ }^{13}$

illius et roseo flammatur purpura vultu et gemmis lux maior inest et blandius aurum: atque ipsi par forma deaest, si pectoris angues ponat et exempta pacetur casside vultus.

Ach. $1.297-300$

Purple is set alight by her rosy face, and the light in her jewels is greater than theirs, and her gold is more alluring: her form would even be a match for the goddess herself, if she were to remove the snakes from her breast, and if her face, with helm removed, were at peace.

It is worth noting that Statius stresses that Pallas is not carrying weapons - as if to quell any fears that Deidamia and her sisters might be overstepping their station, and acting too much like the goddesses he compares them to. In a similar way, when Lycomedes lays on a banquet for Ulysses, his daughters enter the hall "quales Maeotide ripa, / cum Scythicas rapuere domos et capta Getarum / moenia, sepositis epulantur Amazones armis." (Ach. 1.758-60 - "just as on the Maeotian bank, when they have pillaged Scythian houses and the captured walls of the Getae, the Amazons feast with their weapons set aside.") There are strong verbal parallels between Statius' depiction of Deidamia and two passages from Propertian elegy: ${ }^{14}$
ausa ferox ab equo quondam oppugnare sagittis
Maeotis Danaum Penthesilea rates; aurea cui postquam nudavit cassida frontem, vicit victorem candida forma virum.

Prop. 3.11.13-16

Wild Penthesilea once dared to attack the ships of the Danaans from horseback with Maeotian arrows, and after the golden helm laid bare her brow, her radiant form conquered the man who had conquered her.

\footnotetext{
${ }^{11}$ The Scyrian maidens are referred to as an agmen at Ach. 1.301, 602, 623, 799, and 900, and the military connotations of the term are reinforced by its use to describe the Greek armies sailing against Troy at Ach. 1.555 and 786.

${ }^{12}$ Again, there is a parallel with Nausicaa at Od. 6.102-9 and Dido at Aen. 1.498-504. These parallels stress the strength of Deidamia's character and her role as the heroine of the epic, but they do not seriously inhibit my argument, because such similes likewise complicate the characters of Nausicaa and Dido.

${ }^{13}$ It is worth noting the parallels between this passage and Ach. 1.161-5: Deidamia is not only like Pallas, but like Achilles himself, a parallel that bridges his transvestism and imparts some of the qualities of each character onto the other; Achilles appears more feminine and rosycheeked, while Deidamia appears wilder and more dangerous - cf. Rosati (1992), 240 (and also Oliver (2011), 83-85), on Deidamia: "tendente a una certa mascolina energia" ("she tends towards a certain masculine energy.")

${ }^{14}$ Each of these elegies will also be discussed in more depth below.
} 
"magno Tiresias aspexit Pallada vates,

fortia dum posita Gorgone membra lavat."

Prop. 4.9.57-58

"It was at a high price that Tiresias the seer gazed at Pallas, while with the Gorgon removed, she bathed her strong limbs."

In particular, note that in these couplets the removal of the Amazon Penthesilea's golden helmet ("aurea cassida", cf. Ach. 1.298 and 300) reveals her beauty ("forma", cf. Ach. 1.299) to Achilles, just as virginal Pallas' beauty is emphasised by the removal of her aegis for bathing ("posita Gorgone", cf. "angues / ponat", Ach. 1.299300). ${ }^{15}$ Nevertheless, each mythological figure maintains a dangerous edge, and in some way is (or was) a threat to the man gazing upon them. The same is true for Statius' Scyrian maidens; while their chaste and beautiful demeanour is emphasised by their lack of weapons, the very mention of those weapons and comparison to these mythological figures brings their more violent side to the fore, manipulating the trope of wild virginity that Statius uses in his comparison of Achilles to Diana. ${ }^{16}$

This innate wildness is regularly implied throughout the maidens' appearances in the Achilleid. ${ }^{17}$ At Ach. 1.799-800, Ulysses encourages Achilles to abandon his transvestism by exclaiming that even timid mothers and virgin bands want to fight at Troy ("vix timidae matres, aut agmina cessant / virginea"). Seemingly in fulfilment of this statement, at Ach. 1.949-51 Deidamia asks Achilles why she cannot carry martial standards alongside him at Troy, drawing a parallel between those Martia signa and the Bacchea sacra that she and Achilles carried together in the Bacchic festival ("cur non ego Martia tecum / signa feram? tu pensa manu Baccheaque mecum / sacra... tulisti." ${ }^{\prime 18}$ ). Even the chaste dances of the Scyrian maidens are laced

\footnotetext{
${ }^{15}$ This passage draws on Callimachus' fifth hymn, The Bath of Pallas, but (at least in this passage) the similarities between that poem and the Achilleid are weaker than between the Achilleid and Prop. 4.9 - Statius resonates far better with the Latin Propertius than with Callimachus.

${ }^{16}$ The lack of weapons may also encourage the assocation of these passages with the upcoming depiction of Ulysses' gifts. As Oliver $(2011,85)$ notes, the ludicrously overstated "gender essentialism" of the maidens' disinterest in the masculine weapons that Achilles so desires at Ach. 1.848-51 is destabilised by the suggestion (in these passages and at Ach. 1.94950) that the Scyrian women are exactly the kind of people who should be interested in those weapons.

${ }^{17}$ Hinds $(2000,237-9)$ presents a similar argument concerning the destruction of gender boundaries for women in the Achilleid.

${ }^{18}$ I have chosen "pensa" over Dilke's "thyrsa" in Ach. 1.950. While "thyrsa" is more consistent with the Bacchea sacra, "pensa" is better supported in the manuscript tradition, is precedented by the juxtaposition of "pensa manu" with Bacchic objects at Ach. 1.261 and 1.654, and resonates far better with Propertian elegy (as the final chapter will consider).
} 
with this trope: at Ach. 1.832-4 Statius states that they dance in an arrangement called "the Amazonian comb", and clap in a circle like Spartan girls dancing with Diana ("nunc obvia versae / pectine Amazonio, modo quo citat orbe Lacaenas / Delia plaudentesque suis intorquet Amyclis.").

The sacred objects and dances alluded to by Bacchea sacra at Ach. 1.950-51 frequently recur in the context of the Scyrian maidens, encouraging the association of the women with maenadism. Thus when Thetis leaves Achilles on Scyros, she addresses the island with reference to Bacchic dance: "taceasque, precor... / "Hic thiasi tantum et nihil utile bellis:" / hoc famam narrare doce." (Ach. 1.386, 393-94 "and may you be silent, I pray... "Only ecstatic dances are here, and nothing of use for wars." Teach rumour to say this!"). Similarly, thyrsi occur frequently. ${ }^{19}$ Repeated mention is made of cymbals (literally aera, or "bronzes") which were often associated with Bacchic and Corybantian worship: ${ }^{20}$ at 1.622-23, "exercita pulsu / aera tacent" ("the bronzes, disturbed by the beat, are silent"); at 1.714 Diomedes asks Ulysses why he has bought "inbelles thyrsos... et aera" ("unwarlike thyrsi and cymbals"); in the later Scyrian dances, before Achilles is discovered, the maidens "quater aera Rheae... pulsant" ("beat the cymbals of Rhea four times" - 1.828). ${ }^{21}$ Finally, the Bacchic festival itself overtly constructs the women as maenads:

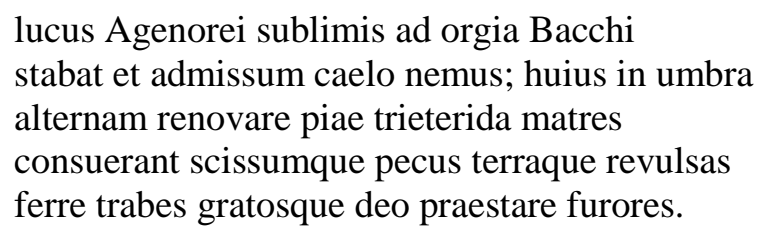

A lofty grove [used] for the mysteries of Agenorian Bacchus stood strong, and a forest received by the heavens; in the shade of this place, dutiful women would renew the triennial rites every other year, and carry cattle that have been torn apart and tree trunks pulled from the earth, and present beloved ecstasies to their god.

\footnotetext{
${ }^{19}$ Eight times - at Ach. 1.572, 617, 634, 648, 714, 830, 839, and 849 (also 950 according to Dilke's reading - see the previous footnote).

${ }^{20}$ For example, note their use in Aen. 3.111 - "hinc mater cultrix Cybeli Corybantiaque aera" ("to this place [came] the Mother who dwells on Cybelus, and the Corybantian cymbals") - or Prop. 3.17.35-36 (a hymn to Bacchus) - "dea magna Cybebe / tundet ad Idaeos cymbala rauca choros." ("the great goddess Cybele will beat her raucous cymbals for the Idaean dances.")

${ }^{21}$ Note that Cybele is often associated with Bacchus. Dilke (1954), 136 notes: "828f. aera
} Rheae. "Cymbals of Rhea", i.e. of Cybele, whose worship became merged with that of Bacchus". 
In particular, note the cattle and trees that are torn apart and given to Bacchus amidst frenzies (furores); there is an element of role-play here. Heslin also notes the maenadic side of the Scyrian maidens, but stresses that in this case they are particularly chaste maenads, and contrary to their depiction in this passage, are generally much tamer than their mythic counterparts. ${ }^{22}$ There is some truth in this depiction of chaste obedient maenads (note, for example, the piae matres of Ach. 1.595), but Heslin perhaps overstates his case with the claim that "there is none of the violence - female violence - that the Euripidean atmosphere portends." As the above examples of dangerous chastity demonstrate, female violence (and transgression) is present in the Achilleid, but as a sub-text rather than a central feature of the plot.

Moreover, the chastity of the women is a final parallel between the maenads of the Achilleid and the Bakkhai. Even in Euripides' work, the maenads are also shown sleeping while cowherds spy on them at Bak. 683-88. The messenger also stresses their passivity (they sit " $\sigma \omega \varphi \rho o ́ v \omega \varsigma "$ (Bak. 686) - "temperately" or "chastely",

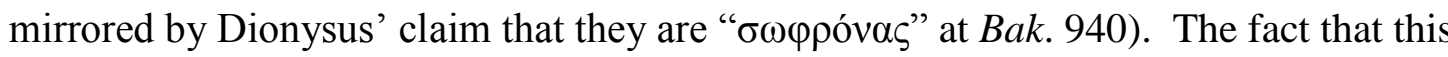
passive side of the maenadic lifestyle is seen in the Bakkhai (a play which requires the maenads' violent side above all) might suggest that the Scyrian maidens' less violent dancing, thyrsus-shaking, and sleeping in the Achilleid is a complement to the violent actions of Ach. 1.596-7, and not necessarily a replacement for them as Heslin implies.

The contrast between appropriate femininity and wild maenadism creates a necessary balance; while certain norms of feminine behaviour have been transgressed, this transgression is paradoxically appropriate as the worship of Bacchus, a sacred duty of the Scyrian women. Indeed, the foreign, wild dancing is condoned by Lycomedes himself at Ach. 1.598-99 (and similar approval is implied at 1.812-14), giving explicit political permission for the actions of the women. Statius's exempla may break down the proprietary boundaries whereby weapons and violence are appropriate to goddesses but not mortal women, making them seem wilder and more volatile, but nevertheless the daughters of Lycomedes do not go so far that their restricted role in the epic (and the Scyrian epic society) is forgotten.

The violent subtext and ambiguous limitations that are placed upon the Scyrian women have interesting implications for Achilles too, insofar as he becomes one of

\footnotetext{
${ }^{22}$ Heslin (2005), 242, 251-5. The parallel between the Bacchic festival and Euripides' Bakkhai will also be explored in more depth in the next section of this chapter.
} 
them. His assimilation into the ranks of Scyrian women and the parallels with Bacchus at Ach 1.292-93 and 615-8 create an approved framework of 'appropriate transgression' that normalises his ephebic transvestism. To some extent, the subtext even provides an outlet for violence through which the rape of Deidamia can be construed as a relatively normal part of Bacchic behaviour in the ritual. This framework of appropriate transgression does not remove boundaries altogether, however; as Thetis' moulding of Achilles implies, it simply imposes new expectations upon the hero. The consequence of Achilles' love, transvestism and (to some extent) rape being construed as appropriate behaviour in Thetis' eyes and within the Bacchic ritual context is that his removal of feminine dress is given a problematic subtext - i.e., it becomes an inappropriate transgression. In this way, Achilles' time on Scyros is figured as a complete inversion of the expected norms that privileges some form of transgression according to every unique model of appropriate behaviour that is provided or implied.

\section{$\underline{\text { Ritual Archetypes }}$}

Statius' depiction of Achilles' rape of Deidamia, while arguably one of the most transgressive actions of the epic, is not nearly as interesting as the context in which he depicts that rape. Despite a Roman fascination for Achilles' youth, the Bacchic ritual setting is unprecedented among the extant examples of the mythos. Moreover, there is no single text (at least among those that have been identified by recent critics) that Statius privileges above others in his depiction of the rape or the ritual setting. Instead, a number of scholars have presented different arguments in recent years in support of a wide variety of intertextual and cultural strands, any of which might be expected to influence an educated reception of the passages concerning the Bacchic ritual. ${ }^{23}$ As this chapter will demonstrate, the plenitude of intertexts presents a number of complications for an examination of transgression. In particular, each text imposes its own set of boundaries and interpretations upon the Achilleid. As with Statius' treatment of transvestism, these conflicts and ambiguities do not simply cancel each other out; rather, they serve to make Achilles an even more

\footnotetext{
${ }^{23}$ Many of these are delineated by Heslin (2005, esp. 236-76), and thus Heslin's work plays a key role in this section. See also Davis (2006) for a summary of several important intertexts. Most of the texts they discuss are also discussed in this section.
} 
problematic figure by signalling a multitude of social boundaries and expectations which do not match his behaviour.

As Heslin identifies, Statius states that the Bacchic festival of the Achilleid is the biennial trieteris. ${ }^{24}$ This festival of maenadism, celebrated on a mountain-top, is the same one that the Theban women of Euripides' Bakkhai are celebrating when Pentheus spies upon them and is torn apart (note trieterida in Ach. 1.595 vs. $\tau \rho \imath \varepsilon \tau \rho i ́ \delta \omega v$ in Bak. 133). Even if Statius had not made the connection explicit, both the emphasis that he places upon ecstatic dance and the construction of the Scyrian women as maenads (as above) encourage an educated audience to read the Bacchic festival in the Achilleid alongside Euripidean tragedy. Achilles' place in this interpretation, however, is troublesome.

To some extent, Achilles can be read as one of the maenads themselves; as noted above, his feminine persona is closely associated with the other Scyrian women. Moreover, an audience could understand his violent actions in the ritual as a manipulation of the violence of the Bakkhai against Pentheus, in the name of the worship of Dionysus. At the very least this interpretation gives Achilles' violation of ritual a mark of divine approval, and it is fitting that he attends the Bacchic rites in clothing similar to a maenad, or to the god himself. ${ }^{25}$ However, if Achilles is a maenad, his rape of Deidamia makes him a singularly bad one. The sexualisation of maenadic violence against another maenad is completely at odds with the chaste rituals of Euripides. ${ }^{26}$ Moreover, the narrative importance of Achilles' rape and

\footnotetext{
${ }^{24}$ Heslin (2005), 244. The festival gets its name, "tri-eteris", from inclusive counting, so it was celebrated once every two years by current reckoning.

${ }^{25}$ I will return to the notion that Achilles' behaviour is modelled on Bacchus' in the following section of this chapter.

${ }^{26}$ Sexualised Bacchic violence can be seen in a motif in which a sleeping maenad is approached by a satyr, though it is not a feature of Euripides' Bakkhai. Heslin (2005), 252, notes that this motif fits Deidamia's situation rather well. This depiction, common in Greek vase painting and adopted in Roman wall-painting and sculpture, can be seen in a literary context in Propertius 1.3, as the poet returns home from Bacchic revelling to find Cynthia asleep on the couch:
}

Qualis Thesea iacuit cedente carina languida desertis Cnosia litoribus; ...nec minus assiduis Edonis fessa choreis qualis in herboso concidit Apidano: talis visa mihi mollem spirare quietem Cynthia consertis nixa caput manibus... Prop 1.3.1-2, 5-8 Just as, while the Thesean ship sailed off, the Cnosian maiden lay, listless, upon the deserted shore; ... nor any less like an Edonian maenad, ${ }^{26}$ exhausted from relentless dances, as she collapses by the 
violation of ritual lies partly in weakening the transvestite facade constructed by his mother. As Achilles' desire to cross-dress weakens, he is pulled away from the effeminacy of male maenadism, and towards the warlike heroism of the Trojan War. Ending Achilles' transvestism in favour of a return to normative masculine society is difficult to reconcile with the free-spirited maenadic nature - indeed, it is a transgression that runs completely counter to everything that the maenadism of Bacchic ritual represents.

Perhaps partly because the rejection of transvestism in favour of epic masculine normativity is so problematic to Bacchism, immediately before Achilles takes up arms and removes his feminine disguise he is directly compared to Euripides' Bacchic enemy, Pentheus. Following Ulysses' arrival on Scyros and his glorification of the coming war (Ach. 1.785-802), as the Scyrian maidens dance for their Greek guests, Achilles begins to resent his transvestism:

$$
\begin{aligned}
& \text { tunc vero, tunc praecipue manifestus Achilles } \\
& \text { nec servare vices nec bracchia iungere curat; } \\
& \text { tunc molles gressus, tunc aspernatur amictus } \\
& \text { plus solito rumpitque choros et plurima turbat. } \\
& \text { sic indignantem thyrsos acceptaque matris } \\
& \text { tympana iam tristes spectabant Penthea Thebae. }
\end{aligned}
$$

Ach. 1.835-840

Then, truly, then Achilles was especially conspicuous, and he did not care to keep to the turns [of the dance] nor join his arms; now, more than before, he disdains the soft steps, now he disdains the garments, and he destroys the dances and creates greater confusion. Thus sorrowful Thebes watched Pentheus, now resenting the thyrsus and drums of his mother, which he had accepted before.

This passage compares the two figures not so much in their initial acceptance of transvestism and effeminacy (where Achilles is implied to be far more similar to the youthful and unbearded aspect of Bacchus himself), but in their rejection of them. In the lines following, when he sees the weapons Ulysses has brought, Achilles is

grassy Apidanus: thus Cynthia seemed to me to breathe in a peaceful sleep, her head leaned upon her interwoven hands...

The eventual rape is also shown in this elegy: while the combination of wine and lust ("hac Amor, hac Liber" (1.3.14) - "Love on this side, Bacchus on that") tempt Propertius to try his luck with Cynthia, unlike Achilles, he does not dare to. Nevertheless, every time she sighs in her sleep, he imagines ".... ali]quis invitam cogeret esse suam." (1.3.30 - “...someone forcing you, unwilling, to be his.") Despite the parallels, this motif does not really form a mitigating precedent for Achilles' actions, as the bestial nature of a satyr makes it highly problematic, and the transgressive implications of the trope are a major impetus for its inclusion in elegy and similar poetry. Elegy's emphasis on transgression (and the Achilleid's use of the elegiac model of transgression) is a focus of my third chapter. 
compared to a young lion - the same beast which Agave and the other maenads believe Pentheus to be as they tear him apart in the Bakkhai (lines 1141-2, 1174, 1196, 1214-5, 1278, and 1283). ${ }^{27}$ The implication is clear: that Achilles' rejection of transgressive effeminacy, just like Pentheus', will lead to his death. ${ }^{28}$

Achilles might also be read as Pentheus within the Bacchic trieteris, as a secret male transvestite attending the feminine ritual, ${ }^{29}$ but there are a number of issues with this interpretation: Pentheus attends the rites from a sense of curiousity, while Achilles' attendance seems to be motivated more by his attraction to Deidamia, and desire to stay hidden; rather than watching the rites from a distance, like Pentheus, with a view to stopping them from happening, Achilles is an active participant; Pentheus' main transgression of the trieteris (aside from his attempts to stop it from happening) is his transvestite attendance at those rites, while Achilles' primary transgression is not his transvestism so much as his rape of Deidamia. In response to the last dissimilarity, Heslin argues that the rape is Statius' masculine Roman answer to Pentheus' unfortunate demise. ${ }^{30}$ He discusses Livy's depiction of the senate's horror at the Bacchanalian affair in $186 \mathrm{BCE}$, arguing that the clash of Greek and Roman religious sensibilities saw Pentheus "considered not as an impious and feckless tyrant, but as a dutiful Roman magistrate.",31

\footnotetext{
${ }^{27}$ Also note (as per the previous chapter) that Achilles is connected with a lion (or a similar beast) at Ach. 1.168-70, 1.746-49, and 2.125, and that the Iliad also compares him to a lion a number of times (King (1987), 18-19ff).

${ }^{28}$ Note the foreshadowing that he will die at Troy (e.g., Thetis' concern that he will die at Troy is the cause of his transvestism, and Deidamia fears he will never return at Ach. 1.927ff). Parkes (2008), 398-401, compares him to the doomed Polynices of the Thebaid. Cf. also Masterson (2005), 308, on the Roman drive to produce a true masculine ideal, as per Statius' Amphiaraus in the Thebaid: "This ever-frustrated impetus toward the ideal suggests both that consciousness and life exist precisely because the ideal is not equaled and that the functional goal of masculine self-acculturation is permanent unconsciousness, i.e., death." A similar model may be operative within the Achilleid, where true heroism is formulated through complete transgression against one's society, ultimately removing oneself from that society, and Achilles' future death is the fate of somebody so excessively heroic and ungovernable that he is irreconcilable with his mortal world, while not being truly immortal either.

${ }^{29}$ Cf. Heslin (2005), 243-54. While Heslin generally argues that "for Statius, [Achilles]... represents the problematic status of the male companion of the "maenads" in the Bacchic mysteries," (248) he also states that "Achilles is here recapitulating the role of Pentheus,... [restoring] the balance of power and of violence in maenadism... to the male sex" (252-3). ${ }^{30}$ Heslin (2005), 252-3.

${ }^{31}$ Heslin (2005), 247-8. Heslin argues that Livy's depiction of the Bacchanalian affair may be considered a Roman reception of Euripides' Bakkhai, which might encourage a Roman audience to associate Statius' reception of the Bakkhai with Livy's Bacchanalian affair.
} 
One major difficulty with Heslin's interpretation of Statius' allusions to the Bakkhai as an orthodox masculine Roman revisionism in line with the senatus consultum de Bacchanalibus that Livy describes (39.8-19) is that the Achilleid manipulates Livy himself as an intertext in an even more problematic manner. ${ }^{32}$ The importance of Livy's work as a moral exemplar and an intertext to Silius Italicus' Punica could certainly encourage resonances for Statius' Flavian audience. ${ }^{33}$ And as a nocturnal Bacchic ritual in a sacred grove ${ }^{34}$ this ritual clearly bears some close resemblances to the trieteris; Livy's grove is sacred to Stimula (a Latin name for Semele), where Statius' grove is sacred to Agenorean Bacchus (Agenor being the grandfather of Semele). Further, in 39.10 Hispala Faecenia, a freedwoman and prostitute, warns a young client (Aebutius) not to attend the Bacchic rites on account of the terrible fate that befell certain other young men: ${ }^{35}$

"eos deducere in locum, qui circumsonet ululatibus cantuque symphoniae et cymbalorum et tympanorum pulsu, ne vox quiritantis, cum per vim stuprum inferatur, exaudiri possit."

Livy, 39.10.7

"[The priests] would lead him to a place which resounded with shrieking and the chanting of singers and the beat of cymbals and drums, in order that his cry of protest, when rape was violently imposed, could not be heard from far off.

When compared with Deidamia's rape in the Achilleid, it is clear that even beyond the obvious parallels of a nocturnal Bacchic ritual in a grove sacred to Semele, there are similarities in the description of the sounds ${ }^{36}$ and with the imposition of vis, but above all in the rape being concealed by the ritual: ${ }^{37}$

\footnotetext{
${ }^{32}$ I am heavily indebted to Jen $\mathrm{H}$. Oliver for encouraging me to pursue this line of inquiry (among others).

${ }^{33}$ For Livy's moral exemplarity, cf. (for example) Chaplin (2000). For work considering the potential importance of Livy to the Punica, cf. Pomeroy (2010), Tipping (2010).

${ }^{34}$ As per 39.10.12: "expromeret sibi, quae in luco Stimulae Bacchanalibus in sacro nocturno solerent fieri." - "she shall reveal to them what things were usually done in the sacred nocturnal rituals in the grove of Stimula, for the Bacchanalia."

${ }^{35} \mathrm{Cf}$. also 39.8.8, where Livy himself narrates the same scene.

${ }^{36}$ For example, the beat of cymbals and drums is a key aspects of Statius' Bacchic dance, as noted above: at Ach. 1.622-23, he mentions "exercita pulsu / aera" ("the bronzes worked by the beat"), and at Ach. 1.654-5, Achilles mentions that "mollia gesto / tympana" ("I bore the womanish drums"). Note also that Ach. 1.646-8 makes it clear that shrieking is a part of Statius' trieteris, as Deidamia's cries are confused with it ("fragor undique notus / tollitur" "the well-known noise is lifted" - at Ach. 1.647-8 may also be understood to refer to a shout or yell).

${ }^{37}$ Note as well that at 39.13.8, Livy claims the festival was originally only for women, and took place on three days a year ("tres in anno...dies" vs. "trieterida" at Ach. 1.595).
} 
vi potitur votis et toto pectore veros

admovet amplexus; ;..

illa quidem clamore nemus montemque replevit;

sed Bacchi comites, discussa nube soporis,

signa choris indicta putant; fragor undique notus

tollitur,...

Ach. 1.642-43, 645-48

He obtains his wishes with violence, and with his whole heart adds real embraces... She filled the forest and mountain with her crying; but the followers of Bacchus, the haze of their sleep shattered, think it is an unspoken signal for the dancers; from all around the wellknown noise is lifted...

Just as with the victims of Livy's Bacchanalia, when Achilles forces himself on Deidamia, her cries of protest are mistaken for the cries of the festival. Thus rather than being constructed as a triumphant Roman Pentheus, Statius' Achilles employs the very sexual aggression that concerns both Pentheus and the Roman senate. His corrupting influence, turning the otherwise pious maenadic trieteris on Scyros into the horrific (and hyperbolic) Bacchanalia of Rome in 186 BCE, is depicted in terms that are unequivocally transgressive and problematic for an educated Roman audience. Yet this transgressive reading might be even more accessible to a Flavian audience given Domitian's attempts to construct his reign as a return to the mores of Augustus and, by extension, Republican Rome: ${ }^{38}$ these are, of course, the same boundaries and ideas which Livy evokes so heavily as an ideal of moral authority which was once operative, and could (perhaps should?) be so again. ${ }^{39}$ A reading of the Achilleidparticularly the Bacchic ritual scene - in light of Livy's moral exemplarity encourages a particular emphasis upon Achilles' transgressive nature.

Another strong literary trope that Heslin considers operative upon Achilles' violent rape of Deidamia in the trieteris is the use of an exclusively female religious festival to meet a lover and to get her pregnant, a particularly well-established motif in

\footnotetext{
${ }^{38}$ Cf., as above, Marks $(2005,209-88)$ for consideration of the relationship between Domitian's moral program and Flavian literature.

${ }^{39}$ A couple of final points of comparison between Livy and Statius is also worth noting here, if only briefly. At 39.15.13, Livy has one of the consuls for that year, seeking to justify the senate's intrusion onto the religous sphere, question whether it would be appropriate for youths initiated in these rituals to take up arms, as Achilles will do later in the Achilleid. He then goes on to suggest that while effeminacy is bad, it is even worse that the youths act in a way that encroaches on the rights of others and even the safety of the state, claiming that "never was there so much evil in the Republic" ("numquam tantum malum in re publica fuit," 39.16.2). Finally he goes on to state that "there is nothing, in fact, more deceptive in its appearance than corrupt religious practice," ("nihil enim in speciem fallacius est quam prava religio") because it offers divine protection for perverse or transgressive acts (39.16.6-7), an argument similar (if a lot more emotionally charged!) to the one I have made for the maenadic status of the Scyrian women above.
} 
New Comedy. ${ }^{40}$ This motif, which derives a lot of its interest from its transgressive nature, even has a real-world exemplum in the form of Clodius, who in $62 \mathrm{BCE}$ disguised himself as a woman and joined the festival of the Bona Dea. ${ }^{41}$ The perception that he must have attended the festival to meet a lover ${ }^{42}$ likely encouraged the adoption of the motif by erotic elegists such as Ovid and Tibullus: ${ }^{43}$

quid faciat custos, cum sint tot in urbe theatra...

...cum fuget a templis oculos Bona Diva virorum, praeterquam siquos illa venire iubet?

A.A. $3.633,637-8$

What can a guardian do, when the there are so many theatres in the city... ....when the Bona Dea drives the eyes of men from her temple, except those whom she herself orders to come?

exibit cum saepe, time, seu visere dicet sacra Bonae maribus non adeunda Deae.

Tib. 1.6.21-22

When she goes out often, be afraid, even if she should say that she [is going] to see the rites of the Bona Dea, not visited by men.

In each of these examples, the nocturnal and exclusively female rites provide an opportunity for a lover of elegy or New Comedy to approach a woman without her husband or guardian being aware. ${ }^{44}$ As Heslin points out, however, Achilles is actually in quite a different situation - he already has access to Deidamia, rendering the motif useless as a plot device, and Deidamia is not a promiscuous woman using the festival setting to escape the watchful gaze of her guardian. ${ }^{45}$ Nevertheless, the disparity in the circumstances of these comic and elegiac heroes and Achilles serves to emphasise the latter's violation of the ritual as unnecessary and especially transgressive.

\footnotetext{
${ }^{40}$ Heslin (2005), 242. Cf. Menander's Epitrepontes, in which the heroine conceives a child at nocturnal festival for Artemis.

${ }^{41}$ For the identity of the Bona Dea and features of her cult, cf. Brouwer (1989) or Staples (1998), or alternatively Servius (In Aen. 8.314) and Macrobius (Sat. 1.12.20-29). The subject is also discussed in more depth below.

${ }^{42}$ Which can be seen, for example, in Plutarch, Caes. 10.1-2.

${ }^{43}$ Meheust (1971, p. 33 n.5) mentions this as a possible influence for Statius: "Allusion possible à Clodius ainsi qu'à Ovide." The link between Clodius and the Achilleid is also briefly discussed by Brown (2005), 89, and Oliver (2011), 95.

${ }^{44}$ Statius was almost certainly aware of a very similar Comedic motif: the use of an effeminate disguise - such as a woman (as in Menander's Androgynos, possibly itself inspired by Euripides' Skyrioi, as per Whitehorne (2000), 311) or a eunuch (as in Terence's Eunuchus) to gain access to an attractive girl. Menander's Samia may offer another example (Plangon becomes pregnant at the feminine Adonia). However, while these examples offer a precedent for Achilles' transvestism, they do not explain the ritual setting.

${ }^{45}$ Heslin (2005), 243, 252.
} 
Similarly, Lorenzo Sanna's 2007 article presents a particularly strong argument that Achilles' seduction of Deidamia should be read in the light of the seductive path for an amator in the Ars Amatoria. Sanna demonstrates that (with the exception of Achilles' transvestism) everything leading up to the rape, and the theoretical act of a rape itself, is in line with the Ovidian narrative, which also includes Achilles and Deidamia's relationship as an exemplum. ${ }^{46}$ It is almost as if Statius' Achilles has used Ovid's little book of love to guide his careful seduction of the princess. Nevertheless, the depiction of the rape is quite different. There is little doubt that Statius' Deidamia is being raped rather than seduced by a suave amator, and the emphasis placed upon Deidamia's distress and the irony that those around her think her cries for help are a part of the ritual forms a clear contrast between the Achilleid and the Ars Amatoria. ${ }^{47}$

Ovid's Deidamia, however, is the preeminent example of his central premise, that women feel a strong sexual attraction to their rapists; that they enjoy being raped:

viribus illa quidem victa est, ita credere oportet: sed voluit vinci viribus illa tamen.

\section{A.A. $1.699-700$}

Indeed, she was overcome by strength - it is reasonable to believe this - but nevertheless she wished to be overcome by strength.

As Amy Richlin describes, Ovid's premise is an "erasure of female subjectivity" insofar as suffering rape is the role assigned to women, Ovid does not even permit them an opportunity to resist. However a similar conformity in action and desire is applied to men, where sexual violence becomes a "signifier of maleness" - Ovid's rape is an assertion of Achilles' heroic masculinity that leaves no opportunity for any continuation of his transvestism or even of his love for Deidamia. ${ }^{48}$

For Statius, on the other hand, the Scyrian rape is merely a catalyst - the first in a series of events that encourage him to abandon his transvestism - and he remains

\footnotetext{
${ }^{46}$ Sanna (2007), especially 214-15. The following chapter will consider this in more depth. ${ }^{47}$ Davis, (2006), 136-37. Basing his argument in no small way on the differences between these passages, Davis goes on to conclude that "Achilleid's account of the relationship between Achilles and Deidamia seems designed as a rejection of values and principles advanced by the teacher in Ovid's Art of Love."

${ }^{48}$ Richlin (1992), 169. All we hear from Achilles following the rape is $A A$ 1.701-2: "iam properaret Achilles; / fortia nam posito sumpserat arma colo." - "now Achilles was hurrying off; for with the distaff put aside, he had taken up strong weapons." Cf. Dilke (1963), 502, Meheust (1971), 31, Heslin (2005), 268, for assessments of the rape as an assertion of heroic masculinity in the Achilleid. The following chapter will further discuss the extent to which the moment of rape itself is Ovidian.
} 
in women's clothing for months afterward. ${ }^{49}$ While he apparently sees the potential for the rape to restore his masculinity (thus Ach. 1.639: "teque marem - pudet heu! nec amore probabis?" - "And that you are a man (alas, how shameful!) will you not prove, through love?"), his actions do not realise this potential. ${ }^{50}$ Even after he eventually does put aside the distaff and take up strong arms, Statius' Achilles does not merely abandon Deidamia. At Ach. 1.903-7, he defends her to her father, and offers to give back the weapons and remain on Scyros. At Ach. 1.927ff, the two spend a last night together before he leaves Scyros, and while he cannot keep his promises of fides (faithfulness, Ach. 1.957) and reversus (returning to her, Ach. 1.958), he is "not unmoved" by her pleas ("non ipse immotus", Ach. 1.956). At Ach. 2.29-30, after he has departed, merely thinking of Deidamia makes him regret his decision to leave: “occultus sub corde renascitur ardor / datque locum virtus." ("The fire (i.e., of love) hidden beneath his heart is reborn, and virtus (courage, manliness, strength) gives up its place.") This version of Achilles may not be the violently transgressive man we have come to expect from the rape and his turbulent time with Chiron, but by that same token, he does completely refuse to conform to the rigid models of masculinity and femininity that Ovid presents in his Ars Amatoria.

It is telling that despite the vast array of intertexts that Statius seems to encourage his audience to recall over the course of the trieteris and rape, Achilles' behaviour appears, at its core, to be entirely unparalleled. If he is a maenadic figure, he is singularly impious and excessive. Similarly, if his actions are a masculine Roman rewriting of the role of the male Bacchic worshipper à la Livy's treatment of the Bacchanalia, the rewriting is completely antithetical to the moral orthodoxy constructed by Livy's Roman Republican senate. Achilles is too senselessly violent to be a conventional hero of New Comedy, and yet simultaneously unusually effeminate for an Ovidian amator. All of these readings are valid interpretations for an educated Roman audience, but not one explains the hero's contradictions or excuses his ambiguously transgressive nature. Instead, they establish false archetypes: precedents which could, hypothetically, partially excuse Achilles' transgressions as appropriate in a certain context, but which invariably fail to adequately model his behaviour, depicting him as more problematic rather than less.

\footnotetext{
${ }^{49}$ Achilles' transvestism itself runs strongly counter to Ovid's teachings on effeminacy (note especially Ars. 1.691-96 and 3.432-52).

${ }^{50}$ Heslin (2005), 268-70.
} 


\section{Bacchus, Hercules and the Bona Dea}

It is fundamentally unnecessary for intertexts to 'explain' characters or events in a text; an intertextual connection may be completely unintentional, or completely fail to resonate with one particular audience, but the effect of an intertext is often a result of its differences from the target text, not just its similarities. ${ }^{51}$ Nevertheless, the failure of all the intertexts considered above to adequately model Achilles' behaviour is rather fascinating. Statius creates the impression that his hero is completely unprecedented - that he is so far beyond the pale that he is completely irreconcilable with the boundaries of his socio-cultural world. In fact, this is the prerogative of a hero. A hero (or heroine, for that matter) is only heroic insofar as he is exceptional: in strength, beauty, intellect or courage, etc., a person must completely excel nearly everybody else in order to become a hero. If a character or hero fits easily into the mould constructed by his or her society there is no reason to pay so much attention to that character, and much of the interest in hearing or telling their story is lost. Achilles' unconventionality may be read in this light; that is, his transgression is part of what makes him truly extra-ordinary.

On this basis, therefore, and on the basis of the excessive character established for him in the seminal Iliad, it makes sense that these intertexts do not easily explain Achilles' behaviour: if he can be easily categorised by his society, he is not truly heroic. It is with this suggestion in mind, and with no intention to justify Achilles' transgressions, that I wish to return to the notion that he is a Bacchic figure. In the previous section I suggested that at some points of the epic Achilles resembles a maenad, and at other times he seems to be playing the part of Pentheus, but conspicuously absent from this analysis was Bacchus himself. Statius has already juxtaposed Achilles with Bacchus, when Thetis used the god as a model of transvestism at Ach. 1.262-63, in her attempt to persuade Achilles to wear women's clothing (“...si decet aurata Bacchum vestigia palla / verrere...” - "...if it becomes Bacchus to sweep his footsteps with a gilded robe..."). ${ }^{52}$

With this foundation, the Bacchic ritual setting allows Statius to develop the comparison between the two in the minds not only of his readers, but of the Scyrian

\footnotetext{
${ }^{51}$ Edmunds (2001), 150-54.

${ }^{52}$ Cf. Seneca's Hercules Furens 465-476, where Amphitryon attempts to justify Hercules' sojourn with Omphale by using Bacchus' gold robe as an exemplum (Kampen (1996), 242).
} 
women, who abandon their religious duties when they see Achilles shake the thyrsus, venerating his beauty and power instead of Bacchus':

illum virgineae ducentem signa catervae magnaque difficili solventem bracchia motu (et sexus pariter decet et mendacia matris) mirantur comites. ...

...[ut] vibravitque gravi redimitum missile dextra, attonito stat turba metu sacrisque relictis illum ambire libet pronosque attollere vultus.

Ach. 1.603-6, 612-14

At this man, leading the standards of a virgin troop and unloosing his great arms with laboured movement, his companions marvel (both his sex and the deceits of his mother grace him equally). ...And [as] he brandishes the garlanded missile in his heavy right hand, the crowd stands in astonished fear, and with the rites abandoned, it pleases them to encircle him and to raise their faces upwards.

The sense that Achilles has somehow usurped the Bacchic rites is then reinforced by the direct comparison of the two in the following lines:

talis, ubi ad Thebas vultumque animumque remisit Euhius et patrio satiavit pectora luxu, serta comis mitramque levat thyrsumque virentem armat et hostiles invisit fortior Indos.

Ach. $1.615-18$

In this way, when Euhius has relaxed his face and spirit at Thebes, and satisfied his heart with the luxury of his fatherland, he lifts the garland and headband from his hair and arms the verdant thyrsus, and, mightier, he visits his Indian enemies.

This simile suggests that as his transvestism weakens, he is pulled away from the effeminate Bacchism signalled as a model for his transvestism at Ach. 1.262-3, and towards the more warlike, civilising imagery of Bacchus that is such a crucial part of the depiction of Roman emperors. ${ }^{53}$ And yet even as Achilles makes this transition into a civilising Bacchus, he barbarically rapes one of his own maenadic worshippers. Such a problematic act is not what an audience might expect - Deidamia is not one of the god's "Indian enemies" of Ach. 1.618 - however at the same time, it is somehow appropriate to Bacchus' ambivalent, polysemous character. The god's free-spirited

\footnotetext{
${ }^{53}$ This depiction seems to have derived from the imperial adoption of Bacchus' role in Hellenistic kingship. Cf., for example, Pun. 17.647-48, or even Silv. 4.2.49, of Domitian reclining serenely at his refined banquet: "sic iacet ad Gangen Indis ululantibus Euhan" ("thus Euhan reclines at the Ganges, amidst Indian shrieking"). The ambiguity between Bacchus as a civiliser and as a free-spirit, or as a warrior and a more peaceful god, is a central feature of the imagery that is created. Thanks to Mark Masterson for proposing this line of inquiry.
} 
approach to the world (cf. the epithet "Liber") is mirrored in Achilles' willingness to transgress, defying the clear distinctions expounded by his society. ${ }^{54}$

Nevertheless an even better model for Achilles' transgressions is Hercules. Like Bacchus, Hercules is a peculiarly ambivalent figure, caught between the models of a civilising hero and a barbaric hero, and of hypermasculinity and effeminacy. This liminal, problematic nature is made particularly apparent in his transvestite transgression against ritual in Propertius 4.9. ${ }^{55}$ Prop. 4.9 is, on the surface, a tribute to Hercules' civilised heroism; an aetiological elegy describing the hero's victory over Cacus and the establishment of the Herculis Invicti Ara Maxima, or "Greatest Altar of Unconquered Hercules". However the bulk of the poem is not taken up with either of these heroic deeds, but with his subversive violation of the ritual of the Bona Dea. After the scene has been set, Cacus has stolen Hercules' cattle and been punished for it, and Hercules has put his cattle to pasture in what will be the "Forum Boarium" - all in the first twenty lines of the poem - Hercules is left paradoxically thirsty and incapable of finding water in a land that only 15 lines earlier was rich, fertile, and watery. His problem is solved with the discovery of a stream in the sacred grove in which the cult of the Bona Dea is celebrated, but the sacerdos at the door refuses him entry on account of his gender (despite him reminding her that he once wore women's clothing in the service of Omphale). In true Herculean fashion, he pushes down the door and drains the stream, and the elegy is concluded with the hero grandly establishing the the Ara Maxima and spitefully declaiming that because he wasn't allowed into the grove, his altar is only open to the worship of men.

The cult of the Bona Dea is not the Greek trieteris or the Bacchanalia introduced to Rome in the $2^{\text {nd }}$ Century BCE, but there are many parallels between the two festivals. In addition to them being women-only, the Bona Dea also has ties to Bacchus, being a fertility goddess often associated with satyric figures - the fauns. ${ }^{56}$ Plutarch also connects her closely with Bacchus in Caes. 9.3: “"E $\lambda \lambda \eta v \varepsilon \varsigma \delta \grave{\varepsilon} \tau \tilde{\varepsilon} v$

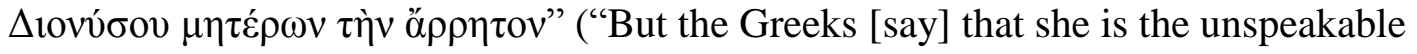
one of the mothers of Dionysos."), presumably referring to the nursemaids of

\footnotetext{
${ }^{54}$ For a closer look at the problematic nature of Dionysos' Bacchic ritual, cf. Schlesier (2011).

${ }^{55}$ For further analysis of these liminal qualities in 4.9, especially with respect to gender and genre, cf. Debrohun (1994), Lindheim (1998), and Janan (2001).

${ }^{56}$ Servius (In Aen. 8.314) connects her with Faunus and the nymphs, while Macrobius (Sat. 1.12.20-29) claims that the Bona Dea is another name for Maia or Terra (and thus closely tied with Cybele), or possibly Fatua, Ops, Fauna, or even Semele herself.
} 
Dionysos on Mt Nysa. ${ }^{57}$ In many ways the ritual of the Bona Dea is an appropriate reference for the Achilleid's ritual, being an early Italian deity connected with Bacchus - the goddess of a "Roman trieteris". 58

The relationship between 4.9 and the Achilleid is grounded first of all in their descriptions of the rituals, where Statius depicts Bacchus' sacred grove using vocabulary remarkably similar to Propertius' depiction of the Bona Dea's grove: ${ }^{59}$

lucus Agenorei sublimis ad orgia Bacchi stabat et admissum caelo nemus; huius in umbra alternam renovare piae trieterida matres consuerant... lex procul ire mares; iterat praecepta verendus ductor, inaccessumque viris edicitur antrum.

Ach. 1.593-6, 598-9

A lofty grove [used] for the mysteries of Agenorian Bacchus stood strong, and a forest received by the heavens; in the shade of this place, dutiful women would renew the trieteris every other year... The law [is that] men [must] go far off; the revered leader renews this command, and the hollow is proclaimed inaccessible to men.

sed procul inclusas audit ridere puellas,

lucus ubi umbroso fecerat orbe nemus...

...et iacit ante fores verba minora deo: 'vos precor, o luci sacro quae luditis antro...'

Prop. 4.9.23-24, 32-33

But from afar he hears enclosed girls laughing, where a sacred grove had made a forest in a shady region...

.... and before the doors he casts words that are less than a god: "You, I pray, who play in the sacred hollow of this grove..."

While there is nothing unique about the use of each of these words to describe a sacred grove, the combination of words is particularly striking. In particular, both texts describe the sacred grove as both a lucus and a nemus (Ach. 1.593-4, Prop. 4.9.24); the same combination of two nearly synonymous terms is used to describe each small woodland area. Shackleton Bailey's use of Ach. 1.593-4 - to demonstrate that Propertius' use of both lucus and nemus in 4.9 is paralleled in other texts - serves to illustrate the rarity of the pairing. ${ }^{60}$ Similarly, both texts describe the grove as 'shady'

\footnotetext{
${ }^{57}$ See also T. P. Wiseman (1974) and Brouwer (1989) for further discussion of the Bona Dea's identity.

${ }^{58}$ Note also A.A. 3.633ff. and Tib. 1.6.21-2, alluding to the example of Clodius (as Plutarch describes), who violated one of her women-only festivals (though not the same one as Hercules, the former being held in the home of a Roman matron, and the latter being held on the Aventine).

${ }^{59}$ Emphases in ancient excerpts are always mine, unless otherwise noted.

${ }^{60}$ Shackleton Bailey (1956), 259. He suggests that lucus and nemus are not, in fact, mutually exclusive: "nemus is the sacred grove regarded as a wood, lucus the wood regarded as a sacred
} 
(umbra in Ach. 1.594, umbroso in Prop. 4.9.24), and call it a 'hollow' (antrum in Ach. 1.599, and antro in Prop. 4.9.33). Indeed, the use of antrum to refer to a grove (as opposed to a cave) is a particularly Propertian practice, not common in Latin, which seems to derive from his adoption of the more flexible usage of the Greek óv $\tau \rho \circ v$ in the Hellenistic period. ${ }^{61}$ The bizarreness inherent in Statius' use of the word (to describe a mountain-going maenadic festival being celebrated in a deep hollow; the absence of a mountain) makes it particularly distinctive, and thus encourages the mental juxtaposition of the passage with Propertian elegy.

The impact of these verbal allusions is further strengthened by both passages' emphasis on a law that has been established to deny men entry into the groves, and an old priestess to enforce it: ${ }^{62}$

lex procul ire mares; iterat praecepta verendus
ductor, inaccessumque viris edicitur antrum.
nec satis est: stat fine dato metuenda sacerdos
exploratque aditus, ne quis temerator oberret
agmine femineo: tacitus sibi risit Achilles.

Ach. 1.598-602

The law [is that] men [must] go far off; the revered leader renews this command, and the hollow is proclaimed inaccessible to men. Nor is this enough: a fearsome priestess stands at the appointed boundary and examines the entrances, lest any violator should wander astray in a band of women; silently Achilles laughs to himself.

grove". He also includes Pun. 6.146-7 and Seneca's Herc. Oet. 1636 as examples, both of which have the potential to be read as allusions to Prop. 4.9. For example, Silius Italicus' use of the words (as well as umbris, mirroring Propertius' umbroso, and antro) describes a grove beside a river in a landscape that is otherwise dry, and the serpent who lives in the grove bears several similarities to Cacus. A complete study would of course be well outside the scope of this thesis, but these parallels do imply that Statius may also have been aware of the use of the combination in 4.9 .

${ }^{61}$ Dilke (1954), 124, Cairns (2006), 132. Cairns' suggestion that this meaning may have been brought into Latin through Parthenius would certainly explain the frequency of its use of Propertius, which Dilke notes. Indeed, Propertius himself seems to associate antrum with the Hellenistic era; in 3.1.5, mentioned above, after he has begged entry into the nemus of Callimachus and Philitas, he asks them "quo pariter carmen tenuastis in antro?" "in what hollow did you thin your song together?"). Cf. also Prop. 1.1.11, and 4.4.3. Statius may acknowledge a programmatic association of this particular usage of the term with Propertius in Silv. 1.2.253, when he includes him in a list of great elegiac poets: “...Umbroque Propertius antro" ("and Propertius, in his Umbrian hollow").

${ }^{62}$ Meheust (1971), 33, highlights the importance of this priestess, writing "without a doubt, Statius was inspired by the cult of the Bona Dea or other similar cults" ("Sans doute Stace s'inspire-t-il du culte de la Bonne Déesse ou d'autres cultes semblables.") - he seems to recognise the similarities between the sacerdos of the Achilleid and the sacerdos who was traditionally a part of the Bona Dea's rites, but does not clarify this connection further, or mention that Propertian elegy may also be a model influencing Statius or the Achilleid's reception. 
talibus Alcides; at talibus alma sacerdos, puniceo canas stamine vincta comas:

'parce oculis, hospes, lucoque abscede verendo; cede agedum et tuta limina linque fuga.

interdicta viris metuenda lege piatur quae se summota vindicat ara casa.'

Prop. 4.9.51-56

Thus Alcides [spoke]; but thus [spoke] the nurturing priestess, with white hair bound by scarlet thread: "Spare your eyes, stranger, and withdraw from this revered grove; go on, yield, and leave these thresholds in safe flight. The altar (forbidden to men) which defends itself in this remote hut is purified with a fearsome law.'

In each case, a degree of expected reverence is constructed around the ritual and its guardians: Propertius describes the grove as verendus and the law as metuenda, while Statius describes the priestess as metuenda, and Lycomedes as verendus. ${ }^{63}$ Moreover, each passages places great emphasis on the hero's violation of this venerable ritual: Statius' description of an "appointed boundary" ("fine dato", Ach. 1.600), and the potential entranceways for a violator ("aditus... temerator", Ach. 1.601) mirrors the Propertian sacerdos' emphasis on the thresholds of the ritual ("limina", 4.9.54) and frequent use of variants of clausus to describe the grove or the puellae (4.9.23, 25, 44, 62). While the two heroes violate the rituals in quite different ways, the simple fact of their transgression is vitally important to the narrative of each text.

Achilles and Hercules are also linked in the erotic elements of their transgression. While Achilles uses the ritual as a cover to rape Deidamia, William Anderson points out that Propertius' Hercules is heavily eroticised in his relationship with the puellae of 4.9. ${ }^{64}$ This can be immediately seen in the juxtaposition of the watery landscape at 4.9.4-6 and Hercules' thirst at 4.9.22 ("terraque non ullas feta ministrat aquas." ("and the fertile earth does not supply him with any water."). The contradiction implicit in this latter passage, that Hercules is in a water-filled landscape and yet cannot seem to find any water at all, is maintained and left unquestioned

\footnotetext{
${ }^{63}$ The different emphases each passage places on the law and its guardians are also worth noting: Propertius uses reverent language around objects (the grove and the law), while the Achilleid uses reverent language to describe people (the guardians of the grove and law). This change may stem from the difference in approach to the two heroes' transgression: Propertius' Hercules, in an open position of power over the women in the grove, only needs to fear divine repurcussions. For Statius' Achilles, on the other hand, in his surreptitious transgression, punishment by the gods is secondary to the immediate potential for discovery by the priestess and punishment by Lycomedes. The Scyrian king is thus painted in similar language to Chiron at 2.164, where the centaur gives iura verenda to the other centaurs, but Achilles is not obedient to either figure.

${ }^{64}$ Anderson (1964).
} 
throughout the elegy. The mention of Hercules' thirst is immediately followed, however, by the laughter of the maidens worshipping in the far-off grove of the Bona Dea, and it is here that he rushes, conveying the sense that he does not thirst for water, but for the women who guard it. Moreover, the words used to describe his thirst sitim at line 21 and again at line 62, not to mention aestum at line 63 - are also often used to describe a burning sexual desire. ${ }^{65}$ Considering Hercules' violation of ritual in this erotic way also provides parallel for Achilles' rape of Deidamia. Where the Ovidian Deidamia wants to be raped, in the Achilleid her unwillingness - and Achilles' aggressiveness - mirrors the unwillingness of 4.9's puellae to allow the volatile Hercules to enter their sacred grove.

In fact (as the first chapter briefly discussed), the Achilleid establishes a relationship between the two heroes quite early on, implying that Achilles thinks of Hercules as a hero to be emulated. When Chiron hands him a lyre, he willingly sings to his mother of the "great seeds of glory", beginning with Hercules' deeds:

canit ille libens immania laudum semina: quot tumidae superarit iussa novercae Amphitryoniades...

Ach. $1.188-90$

Willingly, he sings of the great seeds of glory: how many commands of his puffed-up stepmother the son of Amphitryon overcame...

After singing of Hercules, Achilles goes on to sing about other great heroes - Pollux and Theseus - before finishing with the marriage of Peleus and Thetis, the very beginning of his own future deeds - seemingly constructing himself as the successor to the heroics of these earlier figures. Similarly, when Thetis tries to convince Achilles to wear effeminate clothing, she begins by evoking the memory of Hercules' time with Omphale ("si Lydia dura / pensa manu mollesque tulit Tirynthius hastas..." Ach. 1.260-61 - "if Tirynthius bore Lydian allotments [of wool] and soft spears in his rough hand...”). The vocabulary of this brief allusion to Hercules' time with Omphale, so similar to Hercules' own allusion in $4.9,{ }^{66}$ recurs in descriptions of Achilles' time with Deidamia at Ach. 1.580-83 and Ach. 1.652-55, setting up Hercules as a direct precedent for Achilles in his transvestism and romantic liaisons.

\footnotetext{
${ }^{65}$ Anderson (1964), 11-12, Welch (2004), 74, 83.

66 "idem ego Sidonia feci servilia palla / officia et Lydo pensa diurna colo, / mollis et hirsutum cepit mihi fascia pectus, / et manibus duris apta puella fui." ("I also worked servile duties in a Sidonian mantle and spun my daily allotment [of wool] with a Lydian distaff. A soft band bound my hairy chest, and despite my rough hands, I was an apt girl.”) Cf. also 3.11.17-20, and my further discussion in the following chapter.
} 
The allusions to Hercules throughout the Achilleid (and especially in the Bacchic trieteris) cast Achilles' actions into a heroic frame of reference. The key to this heroic frame, however, lies not in providing a context which excuses transgression, but one which models transgression. Propertius 4.9 depicts a hero who, at his most programmatically and aetiologically Roman, in the course of his most pious, most civilising actions (at least for the Roman world), violates the sanctity of religious rites, portrays himself as a woman, and (it is implied) may even rape young women. ${ }^{67}$ For Propertius, this problematic side is an end for its own sake. ${ }^{68}$ Within the essentialised epic framework of the Achilleid, ${ }^{69}$ on the other hand, Hercules becomes a hero who is not simply heroic despite his transvestism, but because of his transvestism. His propensity to act outside of cultural norms (figured here by his transvestism) is a prime signifier of his heroic nature. Thetis' reference to Hercules at Ach. 1.260-61 implies that transvestism operates in the same way for Achilles. Like Bacchus, Jupiter, Caeneus, and above all Hercules, he will not be governed by the mores placed upon ordinary people, and his heroism is so great that it cannot be impinged by his perceived effeminacy. ${ }^{70}$ Like Hercules in 4.9, he wears women's clothing, violates the sanctity of religious rites, and commits rape, but just like Hercules, these actions are a part of what makes him a hero.

\section{Conclusion}

In the Achilleid, transgression is not simply stepping over a clearly demarcated boundary, such as a line between civilisation and barbarism, or between two genders. Instead, a range of intertexts (which Statius' audience is encouraged to seek out and read alongside the Achilleid) produce a multitude of different sets of mores and expectations for Achilles to live up to - or 'down to'. Some of these sets of mores

\footnotetext{
${ }^{67}$ This dynamic is emphasised by Propertius' use of antrum to refer to the cave of Cacus at 4.9.9-12, implying that the puellae of the Bona Dea are like Cacus (especially as Hercules breaks down the door of both antra) and thus heroising Hercules' violation of ritual. ${ }^{68}$ As Hinds (2000, 225-36) illustrates (and the following chapter addresses in more depth), elegy is a genre particularly concerned with transgression.

${ }^{69}$ This will be discussed in more depth in the following chapter. Cf. also McAuley (2010), 57-58.

${ }^{70}$ Cf. Cyrino (1998, 214): "the heroes' sexual power is not diminished, but rather paradoxically heightened by the imposition of the female disguise." While Cyrino considers transvestism to be a signifier of masculinity and I consider it more as a signifier of heroism, there are several parallels between our arguments, such as in the notion of conveying an idea through its inversion.
} 
regularly conflict and even seem to establish themselves by their difference to another set, as with the boundaries of Chiron's cultivated masculinity and Thetis' cultivated transvestism. Others, such as Livy's mores and Ovid's path for the amator, emphasise the same aspects of Achilles' transgressive behaviour (a particularly violent rape at a religious festival), but consider it to be transgressive for quite different reasons. Particularly interesting are the models of Bacchus and Hercules, for whom inappropriate behaviour itself is normative (albeit two different models of such behaviour), and true transgression can only be realised in a failure to transgress in the manner expected of such a hero. Above all, the combination of these various models of behaviour ensures that transgression is as ambiguous and problematic as the hero's ephebic appearance; rather than a right path and a wrong path, Achilles is left with several entirely unique paths which, it is implied, are all incorrect. ${ }^{71}$

A similar dynamic can be applied to the Achilleid's genre: the expectations formed by a myriad of intertexts create a dynamic that is as confusing as it is exciting. As Hinds puts it, "[the Achilleid] has often seemed to modern critics to be so peculiar as to resist classification as an epic on any comfortable terms whatsoever."72 One of the major reasons for this is the epic's heavy use of elegiac tropes, ideologies, and intertexts, which problematise its status as an epic. As the poetry of transgression and the arma/amor dichotomy, ${ }^{73}$ elegy is particularly well-suited to the Achilleid as we have it, and a perfect genre to aid in the transition of an epic Greek Achilles (especially his tumultuous youth) into a Latin context. This will be the focus of the following chapter.

\footnotetext{
${ }^{71}$ Superficially it would be accurate to say that they are actually all "right" paths when looked at from the correct perspective, but Statius doesn't approach them from this perspective. When Achilles dons feminine clothing his bestial lust and his shame at failing Chiron are emphasised, and when he removes that clothing he is compared to Pentheus being torn apart each action he takes is problematised in some way.

${ }^{72}$ Hinds (2000), 241.

${ }^{73}$ Hinds (2000), 221-36. Hinds also identifies some of the elegiac dynamics at play in the Achilleid (such as the armalamor dichotomy), though he takes his argument in a somewhat different direction.
} 


\section{Chapter Three: Elegiac Themes in the Achilleid; or, All's fair in Love and War.}

"He that cannot dissemble in love, is not worthy to live. I am of this mind, that both might and mallice, deceite and treacherie, all perjurie, anye impietie may lawfully be committed in love, which is lawlesse."

\section{John Lyly, Euphues: The Anatomy of Wyt}

nec tibi, qua tutum vati, Macer, arma canenti

aureus in medio Marte tacetur Amor.

et Paris est illic et adultera, nobile crimen,

et comes extincto Laudamia viro.

si bene te novi, non bella libentius istis

dicis, et a vestris in mea castra venis.

Nor by you, Macer - as far as is safe for a poet singing arms - is golden Love silenced in the midst of Mars. Both Paris and his mistress are there, the famous crime, and Laudamia, companion to her dead husband. If I know you well, you do not sing of wars any more willingly than of these things, and you are coming from your camp into mine.

Ovid, Amores 2.18.35-40

The previous two chapters have demonstrated that Statius places a particular emphasis upon boundaries, which brings Achilles' transgression of those boundaries to the fore. The present chapter will reconcile the discussion of transgression with the generic program of the Achilleid, and consider how Statius uses elegiac tropes and intertexts to make Achilles' transgressive heroism accessible to his audience. I have already noted that the Achilleid has an intertextual engagement with elegy, most notably in the intertextual role of Propertian elegy and Ovid's Ars Amatoria, and also, to some extent, with Tibullus' work. To these elegiac texts it would be fair to add Catullan poetry and the Metamorphoses, as 'pseudo-elegy'. These intertexts are controversial, and despite the frequency of elegiac allusions, the essentially epic nature of the Achilleid has been repeatedly stressed in recent scholarship. ${ }^{2}$ Nevertheless it is paradoxically saturated with elegy, disrupting the essentialism of the epic's generic program; ${ }^{3}$ erotic elegy plays a central role in understanding the relationship between Achilles and Deidamia, and indeed, the Achilleid as we have it.

\footnotetext{
${ }^{1}$ These texts may not be elegy in a strict sense, but Catullus has a great influence over later elegy, and the Metamorphoses is a rather 'elegiac' epic (cf. Hinds (1998), 142-4).

${ }^{2}$ Cf. McAuley (2010), 40, for a discussion of these.

${ }^{3}$ By no means do I intend to stress that the elegiac intertexts are the only side to the Achilleid; for example, the Iliad and Aeneid are also useful intertexts in many ways, and much work still
} 
Defining a work in terms of genre can be helpful, but it is also inevitably problematic - especially so in this case, given that the only way to strictly define elegy is metrically, and of course in this sense the Achilleid is not elegiac at all. It even retains the typically epic omniscient narrative, rather than the subjective approach seen more often in elegy, and its subject matter (the life of the first great epic hero) is as epic as it is possible to be. But even as the Achilleid avoids the elegiac form, it employs elegiac ideas, which will be particularly clear through the consideration of tropes such as servitium amoris, miles amoris, and the recusatio. Statius develops and adapts elegiac ideas through intertexts, constructing an epic model that mimics generically ambiguous poetry such as Ovid's Metamorphoses (as Hinds has argued) ${ }^{4}$ or Propertius' fourth book. ${ }^{5}$

The concept of generically ambiguous poetry is also problematic because it is built upon the notion that various forms of Latin poetry maintained an awareness of their genre that dictated their use of themes or styles. While this is certainly true to some extent, the sharp theoretical division that is often drawn between elegy as the poetry of amor and epic as the poetry of arma is not nearly so well defined in practice; it would be unusual for a Latin epic not to include amatory themes to some degree, especially after the Aeneid. As Hinds demonstrates, however, this idea is not anachronistic. Elegiac poets often seek to define their work by how it diverges from epic, an essentialism that results in a sharp line being drawn between the two genres, but having created a division between arma and amor, elegy then seeks to disrupt it, making their work - or an epic poet's work - more transgressive. ${ }^{6}$ The consequence of this notion, however, is that an epic poem's awareness of the appropriateness or inappropriateness of its generic program is partially constructed upon an elegiac definition of genre.

remains to be done on the dramatic elements of the epic - cf., for example Feeney (2004), Davis (2006), 139-141, and Fantham (1979).

${ }^{4}$ Hinds (1998), 142-4.

${ }^{5}$ For Propertius, the elegiac meter and even in some cases the subjective first person narrative are still present, but they are developed amidst very Callimachean aetiological themes and political ideas about the Roman principate. Debrohun $(1994,61)$ claims that Propertius' fourth book reveals him to be a "literary [transvestite]": that is, a poet who disguises his elegiac genre under the mantle of aetiological epic. The Achilleid also toys with 'literary transvestism', by developing elegiac tropes and allusions in an epic medium, alongside aspects of epic discourse.

${ }^{6}$ Hinds (2000), 221-36. The previous chapter has already dealt with similar ideas, arguing that Statius constructs multiple sets of expectations for Achilles, all of which are broken in some way. 
It is within this frame that Ovid seeks to problematise the amatory content of Macer's epic as indicative of the all-pervading metapoetic power of Amor to cross even generic boundaries, and therefore portrays elegy and epic as two different literary castra (military camps). It may not be an issue that Macer himself was concerned about, but Ovid claims he cannot write a true epic with amor as well as arma, and Amor just doesn't play by the rules. Love's refusal to be bound by a simple set of rules is still a prominent theme today, in the aphorism, "All's fair in love and war", an early form of which is John Lyly's passage above. However this modern concept is somewhat antithetical to Latin elegy, in that it implies that love is not bound by any rules. Rather, Hinds argues, elegists deliberately construct rules - among them the idea that amor is the sole domain of elegy - in order that they might be broken. To speak in moralistic terms, the appeal of erotic elegy is not that it presents love as amoral (as Lyly implies), but immoral.

In the first section of this chapter, I consider the way in which Statius signals the ambiguous generic program of the Achilleid by combining epic, elegiac and Callimachean themes in the proem. Secondly, I examine Statius' manipulations of pudor, ${ }^{7}$ considering its effect on Achilles' amor, stuprum and transvestism, and its role as a social inhibitor demarcating a boundary of appropriate action. Ironically, given its role as a social inhibitor, pudor actually contributes to the morally ambiguous depictions of Achilles and Deidamia, signalling a desire to act inappropriately. In a work that embraces the idea of crossing boundaries, a feeling of pudor signals a boundary that it is possible to cross, and thus becomes as a catalyst for transgression. Next, I consider the way that the elegiac gender inversions of servitium amoris (or erotic servitude) operate upon Achilles' transvestism, and the dubious nature of Deidamia's dominance over him. Finally, I consider the similarities between the Achilleid and elegy in their depictions of the juxtaposition of arma and amor, the thematic representation of the divide between epic and erotic elegy.

As an example, one of the transgressive elegiac tropes that has already been considered in depth as operative in the Achilleid is the furtivus amor (secret love) presented in Ovid's Ars Amatoria as a tool for getting a puella to fall in love with the amator; Sanna persuasively argues that the furtivus amor of Achilles and Deidamia follows this model. As he demonstrates, the secrecy of their relationship evokes the

\footnotetext{
${ }^{7}$ The concept of pudor will be considered in more depth in the upcoming section.
} 
deceptions and hidden meetings of elegiac amores, and heightens the sense that it is something forbidden. ${ }^{8}$ Each of the tactics employed by Achilles evokes Ovid's teachings: the young hero befriends Deidamia (Ach. 1.566); he glances at her (Ach. 1.569); he playfully hits her with baskets, garlands and a thyrsus (Ach. 1.571-2); he sings with her (Ach. 1.572-5); he even kisses and embraces her (Ach. 1.575-6). ${ }^{9}$ Eventually of course, this flirting ends in the rape which the Ovidian puella desires, but which Deidamia clearly does not, and the idyllic furtivus amor is shattered by the violently transgressive stuprum (rape).

Statius' adoption of elegiac tropes, mechanisms, and imagery such as furtivus amor programmatically establishes the Achilleid as a work drawing on a tradition of Homeric epic through a body of 'lesser' Latin poetry. ${ }^{10}$ These tropes begin to ascribe qualities of an elegiac amator to Achilles, a troublesome portrayal for an educated Flavian audience which heightens the sense that he is a transgressive figure.

Moreover, as with the stuprum that concludes the Ovidian furtivus amor, these tropes are often inverted in some way, taken to tenuous extremes, or evoked only to be abandoned. These forms of ambiguous engagement with the elegiac intertexts help to construct Achilles as the hero of passionate extremes that he is in the Iliad; in a sense, his transgressions even overtake the ambit prescribed to elegiac transgressions. Thus the problematic character and passionate liminality of Homer's Achilles is maintained in the Achilleid, but not merely through the privileging of epic intertexts. Instead, the dangerous Greek hero is normalised and lovingly developed for a Roman audience through the extensive use of elegiac intertexts, where such passionate transgression is not only appropriate, but expected.

\section{$\underline{\text { Statius' Proem and Recusatio }}$}

The Achilleid's awareness of its problematic generic status is made clear very early in the poem, with its multivalent proem. Statius introduces his epic subject in a decidedly epic fashion, as "Magnanimum Aeaciden formidatamque Tonanti / progeniem" ("The great-hearted descendent of Aeacus and offspring feared by the

\footnotetext{
${ }^{8}$ Sanna (2005), 207.

${ }^{9}$ See Sanna (2005), 209-13 for a more in depth examination of the Ars Amatoria and the Achilleid.

10 "Lesser" Latin poetry refers to poetry that is not epic, or to epics with generically ambiguous poetry.
} 
Thunderer" - Ach. 1.1-2). ${ }^{11}$ Following lines continue this emphasis upon Achilles' heroic nature, for example, Ach. 1.3-4 immediately recalls his role in Homeric epic (“...acta viri multum inclita cantu / Maeonio...” - “...the man's deeds, greatly celebrated in Maeonian song..."). Nevertheless, Alessandro Barchiesi demonstrates that other parts of the proem are far more Callimachean or elegiac, creating a degree of generic uncertainty. ${ }^{12}$ For example, he notes: incautas... Amyclas (Ach. 1.21) has a model in the Ars Amatoria (where armiferis Amyclis (Ars. 2.5) is associated with the erotic muse Erato); ${ }^{13}$ sic amor est (Ach. 1.5) introduces amatory themes, just as Ovid claims Macer will in Am. 2.18.35-40; ${ }^{14}$ the use of deducere (Ach. 1.7), which is regarded as particularly Callimachean, and is adopted in 'lesser' Latin poetry (for example, in the very generically ambiguous Metamorphoses (Met. 1.4), and even in that same Am. 2.18, line 1 ("carmen ad iratum dum tu perducis Achillen..." - "While you lead your song to angry Achilles...")). ${ }^{15}$

In line with the Callimachean deducere, Ruurd Nauta establishes that Statius includes a recusatio in the proem of his epic, in which he claims that his Achillean project is the prelude to a Domitianic epic: ${ }^{16}$

at tu, quem longe primum stupet Itala virtus Graiaque, cui geminae florent vatumque ducumque certatim laurus - olim dolet altera vinci -, da veniam ac trepidum patere hoc sudare parumper pulvere: te longo necdum fidente paratu molimur magnusque tibi praeludit Achilles.

Ach. $1.14-19$

But you, at whom Italian and Grecian manliness has been astounded for a long time now, for whom the twin laurels of poets and princes flourish in competition with each other (the former is pained to have been conquered), grant me an indulgence and permit me, for a little while, to sweat nervously in this dust: I am working on you, but I am

\footnotetext{
${ }^{11}$ Dilke $(1954,79)$ notes that the opening recalls Vergil's "arma virumque", and that Aeacides is a Homeric patronymic.

${ }^{12}$ Barchiesi (1996), 62.

${ }^{13}$ Note that Erato is also the muse invoked by Apollonius in his Argonautica, a mythos recalled by Thetis repeatedly in the following lines of the Achilleid with the mention of Helle (1.24), Phrixus (1.28), Lapitharum proelia (1.40 - note that many of the Lapiths were also Argonauts, and vice versa), Iasonia rapina (1.65), and the Argo's semidei and Theseus (1.712). Erato also appears at Aen. 7.37, signalling the introduction of Lavinia.

${ }^{14}$ And it is also a detached phrase early in the poem, a feature associated with Callimachus (and later the Metamorphoses) as per Heslin (2005), 73-74.

${ }^{15}$ Cf. Hunter (2006), 127-30, and Nauta (2006), 23 - the famous incidence is Vergil's Ecl. 6.5. Heslin $(2005,75)$ also associates deducere with Prop. 2.1.17-18.

${ }^{16}$ Nauta (2006), 31-34. Note the parallel at Silv. 4.4.87-100, where Statius airs some concerns to Marcellus about the two possible epics, and at the Theb. 1.17-34, where Statius first promises to write an epic to Domitian at some non-specific time in the future.
} 
not yet confident in my long preparation, and great Achilles will be your prelude.

Nauta tracks the evolution of recusatio from the proem of the Aitia of Callimachus through Latin (and especially Flavian) poetry, resolving to address the absence of scholarship on the use of the trope after the Augustan elegists. The role of a recusatio, to excuse the privileging of a 'smaller' or 'poorer' poetry over a 'greater' one, is particularly appropriate for Augustan elegists reluctant to pursue an epic, but this extensive use (especially by Propertius and Ovid) makes it a particularly interesting tool for introducing an epic in the Imperial era. In what Barchiesi calls "un bel complimento" to Domitian, ${ }^{17}$ Statius follows the model set by Valerius Flaccus (Arg. 1.11-14) ${ }^{18}$ and his own Thebaid (Theb. 1.32-4) ${ }^{19}$ of using a recusatio to excuse his privileging of heroic epic over a hypothetically greater (if somewhat more elusive) panegyrical epic.

Insofar as it fulfils this established model introducing lesser poetry (such as elegy) a recusatio is certainly an interesting feature for an epic, but as noted above, it is a common feature in Flavian epic, and thus does not necessarily signal a more programmatic undercutting of epic; ${ }^{20}$ praise of the emperor requires a certain modesty on the part of the poet. Nevertheless, other elegiac (and Callimachean) elements in the proem make this recusatio appear to be undercutting the epic essentialism of the Achilleid. At Ach. 1.8-11, Statius phrases his prayer to Apollo using elegiac imagery:

tu modo, si veterem digno deplevimus haustu, da fontes mihi, Phoebe, novos ac fronde secunda necte comas: neque enim Aonium nemus advena pulso nec mea nunc primis augescunt tempora vittis.

Ach. 1.8-11

But you, if I have depleted the old [spring] with a worthy draught, give me new springs, Phoebus, and bind my hair with favourable (lit. "second") leaves: indeed, I do not knock at the Aonian grove as a newcomer, and it is not just now that my temples are increased with the first ribbons.

These four lines in particular seem to have a stylistically affinity with the Callimachean landscape of Propertius' elegy: Dilke compares Statius' request for fontes novi to the sacerdos' reply to Hercules at Prop. 4.9.58 ("di tibi dent alios

\footnotetext{
${ }^{17}$ Barchiesi (1996), 56.

${ }^{18}$ Nauta (2006), 27-30.

${ }^{19}$ Nauta (2006), 30-31.

${ }^{20}$ contra Heslin (2005), 78.
} 
fontes" - "may the gods give you other springs"), ${ }^{21}$ while Barchiesi and Heslin are reminded of two lines from the extended recusatio in Propertius' third book, in which he dreams that Apollo warns him to stay away from epic: ${ }^{22}$

parvaque iam magnis admoram fontibus ora (unde pater sitiens Ennius ante bibit...)

Prop. 3.3.5-6

And I had already put my little lips to the great fountain (from whence Father Ennius once thirstily drank...)

In fact, the use of fons to refer to a fount of inspiration from Apollo or the muses is a trope adopted by Propertius in several other places. ${ }^{23}$ Moreover, the verbal parallels with Prop. 3.3 continue with Statius' use of Aonium nemus:

nil tibi sit rauco praeconia classica cornu flare, nec Aonium tingere Marte nemus;

Prop. 3.3.41-42

Let it not be a concern for you to sound the war-trumpet's summons with a husky horn, nor to stain the Aonian grove with Mars...

The verbal parallels between these programmatic works - each including a recusatio encourage an audience to associate the Achilleid with elegy. And yet it is worth noting that Statius seems to be permitted everything that Propertius is refused. Only three lines earlier, Statius had hoped for permission from the muse to lead Achilles forth from his Scyrian hiding place with the blast of a trumpet ("velis Scyro... latentem / Dulichia proferre tuba", Ach. 1.5-6), a war-trumpet's summons similar to that in this passage which is forbidden to Propertius. Similarly, Barchiesi argues that Statius claims to have already depleted the fontes of Ennius that Apollo denied the elegiac poet ("si veterem digno deplevimus haustu," Ach. 1.8). ${ }^{24}$

Barchiesi goes on to show that Statius mentions the Thebaid as a model for the Achilleid to some degree; while Statius' fontes are novos ("new"), which might suggest a programmatic shift, his garland is called secunda ("second"), ${ }^{25}$ implying a

\footnotetext{
${ }^{21}$ Dilke (1954), 80.

${ }^{22}$ Barchiesi (1996), 54, Heslin (2005), 77.

${ }^{23}$ And also associated with Callimachus: 2.10 .25 (Ascraeos... fontes), again in reference to epic inspiration as opposed to Permessi flumine; 3.3.51, referring to the spring of Philitas; and 3.1.3, a recusatio bearing many similarities to 3.3 , where Propertius begs that as puro de fonte sacerdos ('a priest from a pure spring'), he might be permitted entry into the nemus of Callimachus and Philitas. Fons is also used this way in Amores 3.1.3, one of Ovid's recusationes, and in 3.9.25, his lament for Tibullus - both of which draw heavily on Propertius and Callimachus.

${ }^{24}$ Barchiesi (1996), 51-2.

${ }^{25}$ Note the ambiguity inherent in secunda - it means both "second" and also "favourable", as Heslin (2005), 76-78.
} 
certain degree of continuity between the two epics - at least insofar as they are both epics. And an Achilleid cannot really be anything else; the popularity of the Iliad makes Achilles the most famous - most heroic - hero of literary history, and in line with the Homeric intertext he establishes at Ach $1.1-7,{ }^{26}$ it would not really make sense for Statius to describe such an 'epic' theme in lesser verse. On this basis, Barchiesi concludes that the proem's epic features appear to construct the Achilleid as "a kind of super-epic" ("una sorta di super-epos"), balanced by "the forces of disorder - erotic, anti-epic" ("le forze di disturbo - erotiche, anti-epiche"). ${ }^{27}$ He then argues that the major theme of the epic is Statius' attempt to reconcile these contradictory elements of "programmatic theatre" ("teatro programmatico"), and thus "to raise" ("far crescere") Achilles. ${ }^{28}$

I noted in the introduction to this chapter that an epic poem's awareness of its generic program is partially constructed upon the elegiac definition of epic as the poetry of arma. For Statius to emphasise the epic nature of the Achilleid he must engage with elegiac ideas, which then paradoxically destabilise that epic nature. Unlike Macer in Am. 2.18, Statius does not acknowledge the role of amor in the Trojan War story, and he alludes to the Propertian recusationes only to differentiate the Achilleid's poetic program from them. But the fact that this epic essentialism is so ludicrously overstated encourages an audience to question it, and Statius' use of elegiac and Callimachean allusion provides this opening.

This program of oppositions is constantly manipulated in the proem and recusatio of the Achilleid. Statius first invokes the muse, establishes the place of Homer as a generic and contextual model, and sets out the limits of his epic subject (Ach. 1.1-7). Next, he offers a prayer to Apollo, establishing himself as the poet of the Thebaid and setting up the Achilleid as his second epic (Ach. 1.8-13). Finally, he makes the traditional Flavian recusatio to Domitian, praising the emperor and modestly downplaying his epic in relation to a hypothetical imperial panegyric (Ach. 1.14-19). In this way, the proem maintains an external epic decorum. Throughout the

\footnotetext{
${ }^{26}$ Note that Statius' mention of Hectore tracto (Hector being dragged around) at Ach. 1.6 is also found in Prop. 3.1.28 as an iconic image of the Latin reception of the Iliad: at 3.1.28, Propertius claims that like Achilles himself, the wheels which thrice dishonoured Hector's body ("Hectora per campos ter maculasse rotas") would not be famed at all were it not for Homer.

${ }^{27}$ Barchiesi (1996), 55-62.

${ }^{28}$ Barchiesi (1996), 62.
} 
19 lines, however, Statius embellishes his hexameter with vocabulary and stylistic features that evoke Callimachus, Ovid, and Propertius, using what Barchiesi calls "anti-epiche" to simultaneously reinforce and undercut the poem's epic nature. In the same way, the depiction of Achilles as an elegiac amator, particularly appropriate to his problematic episode on Scyros, simultaneously reinforces and undercuts his heroism.

\section{$\underline{\text { Pudor and the Erotic Gaze }}^{29}$}

Among the elegiac themes that the Achilleid manipulates is the connection between pudor and the violation of mores. The ambiguities of pudor are central to this interaction, and highlight some of the ambiguities involved in any discussion of transgression. Addressing pudor with transgression and violation of mores in mind naturally privileges an interpretation of the word that stresses its implications of "shame" or "embarrassment" rather than "decency" or "modesty", but in fact it would be naive to suggest that these meanings are mutually exclusive, or even two particularly separate meanings, rather than two different connotations of a single idea without an adequate translation. ${ }^{30}$ Pudor is a force for morally upright, positive and appropriate action (as "modesty" or "honour") only insofar as it constructs a sense of wrongdoing and negative emotions (as "shame" or "embarrassment") in those who do not conform to the mores of the culture it acts upon, and this ambiguity makes it a particularly important concept for transgressive elegy. To look at it another way, pudor (as "modesty" or "honour") is the awareness that allows an agent to consciously transgress against their mores,${ }^{31}$ but also (as "shame") a by-product of that conscious transgression.

The fact that pudor is a liminal, ambiguous concept especially active around moral boundaries makes it particularly apt as a theme and poetic tool for elegy, which experiments with the transgression of these boundaries. The same is true for the Achilleid. While Statius employs the word pudor (and its related forms, such as pudet) in both his epics far more often than Vergil, even by comparison to the Thebaid the

\footnotetext{
${ }^{29}$ Particular thanks are owed to Jen Oliver for sparking the idea for this section.

${ }^{30}$ As Barton $(2001,15)$ claims: "Many highly charged Latin words (fides, pudor, sanctitas, gratia, religio, fama) had built in complexes of antitheses that help the hearer, once aware of them, to grasp something untranslatable, indeed, ineffable, in the Roman psyche."

${ }^{31}$ Elegy requires that its transgression be conscious - inadvertent transgression does not create the same degree of interest.
} 
Achilleid is exceptionally concerned with the idea. ${ }^{32}$ This is to be expected, of course, because the subject matter of the Achilleid intersects with pudor to a greater extent than is typical of an epic - the chastity of the Scyrian maidens and Achilles' shame at cross-dressing are exceptionally apt subjects for a consideration of modesty and shame. Nevertheless, Statius manipulates the concept subversively, in a manner that is highly reminiscent of elegy.

Conceptions of pudor in epic tend to revolve around notions of appropriate action for male heroes - a sense of honour that is built upon the opinions of their society. ${ }^{33}$ Statius' Achilles does have pudor in this form, demonstrating an awareness of the boundaries of social interaction, but this awareness is undercut when he violates those boundaries. The first appearance of pudor is in his mother's exhortation to cross-dress:

"cur ora reducis

quidve parant oculi? pudet hoc mitescere cultu?

per te, care puer, cognata per aequora iuro, nesciet hoc Chiron."

Ach. $1.271-4$

"Why do you turn your face away? And what are your eyes saying? Does it shame you to become tame in this finery? I swear before you, dear boy, and before my kin, the oceans, that Chiron will be unaware of this."

As Thetis recognises, Achilles averting his face and refusing to make eye contact implies that his reluctance to wear women's clothing is a decision motivated by pudor - the knowledge that this hypothetical transvestism could be construed as cowardly and rejection of his masculinity. ${ }^{34}$ Having established that Achilles has pudor (i.e. that he is aware of the boundaries of appropriate masculine action, or at least that knows transvestism is perceived to be not appropriate), ${ }^{35}$ Statius then changes the nature of

\footnotetext{
${ }^{32}$ Just comparing the books of each epic with the most occurrences of the word and its related forms, Ach. 1 contains fifteen occurrences (16 if line 661 is included, but there is doubt about its authorship), while Theb. 1 and 8 contain nine occurrences, and Aen. 4 and 9 contain three occurrences.

${ }^{33}$ Cf. Gunderson (2000), 205-6.

${ }^{34}$ It is important to differentiate between internal identity and external persona - here Achilles' concern is entirely external. Achilles himself never seems to think that he is becoming a woman, and thus his identity is internally consistent, but it is abundantly clear that externally (as far as others are concerned) his metamorphosis does go far beyond simple transvestism. See page 24 in the first chapter of this thesis for differentiation between Achilles' external "death" through transvestism, and any kind of literal ("internal") death - the adoption of his feminine persona seems to "blink" him out of existence for Chiron and Sperchius, but as far as he is concerned, he is still Achilles.

${ }^{35}$ See Garber (1992) for a more in-depth discussion of transvestism as transgression.
} 
this pudor from epic honour into a more elegiac modesty, and develops it as a boundary Achilles is liable to cross.

The external motivation for Achilles' submission to his mother's will is, of course, the appearance of Deidamia, whose own pudor is repeatedly emphasised, and even sexualised by Achilles' gaze in a passage in which she appears with her sisters:

omnibus eximium formae decus, omnibus idem

cultus et expleto teneri iam fine pudoris

virginitas matura toris annique tumentes.

Ach. $1.290-2$

For each of them, there was extraordinary grace in their form, for each the same finery, and having filled out the boundary of gentle modesty, their virginity was already ripe for the marriage bed and their years were swollen.

This passage goes on to compare Deidamia to Venus, Diana, and Pallas. The combination of these goddesses forms a voyeuristic sexualisation of virginity that simultaneously emphasises the princess' beauty and chastity; the comparison to Diana and Pallas stresses her youthful pudor while at the same time the comparison to Venus among the nymphs encourages the sexual gaze that might be expected towards one who is matura toris (Ach. 1.292). Upon seeing her, Achilles is overcome by her beauty in a very elegiac fashion. ${ }^{36}$ This is true even to the extent that there is a hint of gender-reversal in the scene: the conflation of Deidamia's chastity with the wild virginity of Pallas and Diana suggests something of the duritia of an elegiac puella, ${ }^{37}$ and Achilles himself will be made soft (mulcetur, Ach. 1.323) by his gazing. ${ }^{38}$

Nevertheless, there is an element of pudor constraining Achilles even here, demonstrating again that he does have an awareness of inappropriate action. Unable to contain his embarrassment at his desire inwardly, he blushes. As Carlin Barton explains, the blush is a somewhat ambiguous expression of pudor. While as an

\footnotetext{
${ }^{36}$ Compare, for example, Prop. 1.1.1-2, in which Propertius catches sight of Cynthia's eyes, and is captivated by them, "miserum me... contactum nullis ante cupidinibus." ("wretched me (Propertius), never before touched with desire."). While the model is much more simplistic in the Achilleid (in that the masculine gaze is not subverted by potentially being returned), there is still the motif in which feminine beauty softens the masculine "gazer" for the very first time, and forces him to revere the subject of his gaze. The shameful loss of self-control that results in the blush of the gazer (or other irrepressible bodily functions, such as a flush, or weakened limbs - cf. Cat. 51) is part of the foundation of the elegiac interest in servitium amoris, along with the reversal of gender roles and violation of mores - see further below.

${ }^{37}$ It is worth comparing this (for example) with Prop. 3.11.13-16, discussed in my second chapter, and below. Note that the pudor of the Scyrian maidens is also mentioned in conjunction with Amazonian imagery at Ach. 1.757.

${ }^{38}$ For further treatment of this form of gender reversal in elegy, see, for example, Greene (2005) 61ff.
} 
expression of embarrassment it often does indicate a desire to transgress in some way, it also indicates a degree of self control and humanises the one blushing to some degree. ${ }^{39}$ However, Statius goes on to qualify Achilles' expression of self-control:

eat atque ultro ferus hospita sacra

disiciat turbae securus et inmemor aevi

ni pudor et iunctae teneat reverentia matris.

Ach. 1.310-2

He would be going forth and, willingly wild, would be scattering the foreign rituals, untroubled by the tumult and unmindful of his age, if modesty and reverence for the mother beside him did not hold him back.

This passage undercuts (at least to some degree) the positive aspects of pudor that Achilles assumes by blushing, in that it implies that it his self-control is conditional upon Thetis's presence; ${ }^{40}$ that if his mother had not been standing beside him, he might have sacrilegiously raped Deidamia in the midst of a festival celebrating the virginal Pallas. ${ }^{41}$ To some extent this too is inaccurate - it is necessary for desire to be clear in order for the control of desire to be meaningful, and these lines do make it clear that Achilles wants to transgress, and yet restrains himself. ${ }^{42}$ Nevertheless, the following simile comparing Achilles to an inflamed bull constrained by cow-herds (Ach. 1.313-17 - considered in the first chapter) suggests that his control of himself is limited, and it must be remembered that the hypothetical disruption of a religious festival in this passage foreshadows the very real disruption that Achilles will cause when he does rape Deidamia at the Bacchic trieteris. Achilles' pudor seems to be little more than a tiny dose of maternal respect; he has an awareness (not possessed by the bull to which he is compared) that his desires are inappropriate, but not nearly enough self-control to restrain himself without an external motivator, such as the opinions of others.

Interestingly, the blushing confirmation of his ambiguous pudor is problematised still further by its portrayal as the threshold of his external gender metamorphosis. Davis shows that the initial language of Achilles' desire recalls

\footnotetext{
${ }^{39}$ Barton (2001), 223-32.

${ }^{40}$ This reverence for his mother is also considered very briefly in my first chapter as a possible result of his well-rounded education under Chiron, and yet, as I demonstrated, it is somewhat problematic.

${ }^{41}$ Just as Locrian Ajax so infamously raped Cassandra by as she sought refuge in a temple to Pallas during the sacking of Troy.

${ }^{42}$ Barton (2001), 216-19.
} 
Dido's passion for Aeneas in the first and fourth books of the Aeneid, ${ }^{43}$ and that Achilles' blush in particular mirrors Lavinia's blush in Aeneid 12: ${ }^{44}$

nec latet haustus amor, sed fax vibrata medullis in vultus atque ora redit lucemque genarum tinguit et impulsam tenui sudore pererrat. lactea Massagetae veluti cum pocula fuscant sanguine puniceo vel ebur corrumpitur ostro, sic variis manifesta notis palletque rubetque flamma repens.

Ach. 1.304-10

Nor does the love that has been drunken stay hidden, but the torch brandished in his inner marrow returns to his face and his expression, and tints the colour (lit. light) of his cheeks, which wanders across him, stirred up, in a light sweat. Just as when the Massageteans darken their milky-white cups with crimson blood, or ivory is destroyed by purple dye, thus the sudden fire is made evident by various signs; he both pales and reddens.

accepit vocem lacrimis Lavinia matris

flagrantis perfusa genas, cui plurimus ignem subiecit rubor et calefacta per ora cucurrit.

Indum sanguineo veluti violaverit ostro si quis ebur, aut mixta rubent ubi lilia multa alba rosa, talis virgo dabat ore colores.

Aen. $12.64-69$

Lavinia hears the voice of her mother, drenched with the burning tears upon her cheeks, on which an intense blush exposed a fire, and ran across her flushed face. Just as if someone violated Indian ivory with bloodstained purple dye, or where many white lilies, mixed with a rose, are reddened, thus the maiden gave colours to her face.

The privileging of feminine love in the Aeneid as an intertextual model for the desire that consumes Achilles as he gazes at Deidamia hints at a continuation of the elegiac gender reversal mentioned above. Rather than being an appropriate epic sense of honour, as it was before, here Achilles' pudor is a rather more effeminate shame at feelings of desire. Where earlier Deidamia was "masculinised" (to some degree) by the association of her wild appearance with the more violent side of Diana and Pallas, here Achilles is feminised by the association of his blushing pudor with the selfconscious desire of Dido and Lavinia. ${ }^{45}$

\footnotetext{
${ }^{43}$ e.g. Davis provides "novum bibit ossibus ignem" (Ach. 1.303) vs. "ossibus implicet ignem" (Aen. 1.660) + "longumque bibebat amorem" (Aen. 1.749), and "fax vibrata medullis" (Ach. $1.304)$ vs. "mollis flamma medullas" (Aen. 4.66).

${ }^{44}$ Davis (2006) 132-3. This contrast of red and white is much used in classical literature, and it is also central to Catullus 64 and the Metamorphoses - cf. Rhorer (1980), 79-88.

${ }^{45}$ Davis (2006), 133. Barton $(2001,225)$ also associates Lavinia's blush with Ovid's Medea (Met. 7.78) and Catullus 65.19-24, models that are fairly close to elegy themselves.
} 
It is shortly after this that Achilles' strong, wild wilfulness (that was earlier ashamed to become tamer through transvestism - cf. Ach. 1.272) is at last "softened" ("mulcetur"), and, still blushing, he permits Thetis to mould him into an even more feminine appearance and posture:

mulcetur laetumque rubet visusque protervos obliquat vestesque manu leviore repellit. aspicit ambiguum genetrix cogique volentem iniecitque sinus; tum colla rigentia mollit... et picturato cohibens vestigia limbo incessum motumque docet fandique pudorem.

Ach. 1.323-6, 330-1

He is softened, and blushes happily, and shamelessly glances out of the corner of his eye, and pushes the garments away with a lighter hand. His mother looks upon his wavering and his willingness to be forced, and casts the folds upon him; then she softens his stiff neck... and confining his footsteps with the decorated hem of his dress, she shows him how to walk and gesture, and be modest in his speech.

In addition to mulcetur, Statius employs further ambiguous elegiac language associated with the mollis amator in his description of Achilles' blush: ${ }^{46}$ his hand is levior, he is ambiguus, and the rigidity of his neck is smoothed out (mollire). ${ }^{47}$ The metamorphic tone is abundantly clear as Thetis moulds Achilles into a more feminine appearance, ${ }^{48}$ but as Davis claims, the phrase "cogique volentem" ("his willingness to be forced," Ach. 1.325) follows the Ars Amatoria more closely; ${ }^{49}$ while the rape of Deidamia was unwilling, Achilles himself seems to want to be raped by his mother, as if he himself were Deidamia, or the hypothetical Ovidian puella for whom she is the exemplum. $^{50}$

One further aspect of Achilles' metamorphosis is worth emphasising. At Ach. 1.323-24, he casts "shameless" glances out of the corner of his eye; this glancing again suggests that his pudor is no longer felt on account of his sense of honour, but his effeminate desire (the notion that he is softened - "mulcetur" - suggests a degree of femininity). This effeminate pudor is reiterated at Ach. 1.331, where Thetis' construction of Achilles' feminine external persona is completed with her teaching

\footnotetext{
${ }^{46}$ For which see, for example, Wyke (1995), or (particularly for a Propertian take on the mollis amator) Greene (2005).

${ }^{47}$ Also note laxare at Ach. 1.327-8 ("fortia laxat / bracchia" - "she relaxes his strong arms"). ${ }^{48}$ Hinds (1998), 138-39.

${ }^{49}$ A.A. 1.699-700, discussed in the previous chapter: "viribus illa quidem victa est, ita credere oportet: / sed voluit vinci viribus illa tamen." ("Indeed, she was overcome by strength - it is proper to believe so - but nevertheless, she wished to be overcome by strength.")

${ }^{50}$ Davis (2006), 136, also citing Dilke (1954), 107.
} 
him "fandi pudorem" ("modesty in his speech"). It is at this point that his transition is made clear. From being ashamed to become tame or soft ("pudet mitescere", Ach. 1.272), Achilles' erotic gaze gradually causes his pudor to evolve. Indeed, as Thetis moulds Achilles' appearance and gestures to be more congruent with his feminine clothing, through a very elegiac inversion his appropriate, masculine pudor signalling concern for his honour and heroic stature is softened into a pudor more appropriate to women, signalling embarrassment for a lapse in modest behaviours and desires. In this way, Statius uses the ineffability of pudor as a mechanism of continuity across boundaries; while the nature of Achilles' pudor has changed, he feels some kind of pudor throughout the entire episode.

Using the ambiguities of pudor to smooth Achilles' transition into transvestism undercuts the moral propriety inherent in the term, but it is also a clever manipulation of its liminal qualities. Statius employs concepts of honour and shame in a similar way at the Bacchic trieteris, when Achilles considers raping Deidamia to prove his masculinity to others. As motivation to start the process of breaking free of his feminine clothing, he reminds himself of the pudor that he already feels as a result of his transvestism, comparing his actions with Patroclus' training for war: ast ego pampineis diffundere bracchia thyrsis
et tenuare colus - pudet haec taedetque fateri -
iam scio. quin etiam dilectae virginis ignem
aequaevamque facem captus noctesque diesque
dissimulas. quonam usque premes urentia pectus
vulnera? teque marem - pudet heu! - nec amore probabis $?^{51}$ Ach. 1.634-9

But I now know how to spread my arms with vine-covered thyrsi, and thin the distaff - it shames and disgusts me to admit these things). Moreover, captured both night and day you (Achilles) conceal your fire and equal-aged torch for the beloved maiden. How long will you oppress your heart with this burning wound? And that you are a man (alas, how shameful!) will you not prove, through love?

In this case, the pudor that Achilles feels as a result of his transvestism is outwardly appropriate, echoing the concern about his honour that his mother suggests he is

\footnotetext{
${ }^{51}$ Cf. the ever-recurrent Amores 2.18, lines 7-8, in which Ovid is ashamed of his amatory themes, and his puella accuses him of being ashamed to love ("iam te' dixit 'amare pudet?" - "'are you now', she said, 'ashamed to love?") - Achilles seems to have his priorities confused, seeing rape as an indicator of "hard" masculinity, where an elegist might connect it with the "soft" desire for a woman.
} 
feeling at Ach $1.272 .^{52}$ It reiterates his awareness that he has transgressed, and his desire to return to his heroic masculine persona, acting not as an inhibitor, but a spur to action. ${ }^{53}$ Even so, the action he takes (raping Deidamia) is paradoxically entirely inappropriate, and is perhaps one of the most outwardly transgressive acts of the epic. It is worth noting that at Ach. 1.644 the moon (Luna) is ashamed to witness the rape, and blushes, while at Ach. 1.671 Deidamia's virginity is referred to as her raptum pudorem $;{ }^{54}$ in attempting to mitigate the shameful pudor of his transvestism, Achilles violates the modest, appropriate pudor of another person, and thus demonstrates the limitations of his reverence for his mother. While rape may be more acceptable for the heroic masculine persona he is adopting, it is merely an exchange of one form of transgression for another.

It is no coincidence that we see pudor associated with the transitional periods of his transvestism and as a motivating factor for his problematic actions. The ambiguous nature of shame makes it especially apt for these passages, where it emphasises the problematic elements of Deidamia's rape and Achilles' transvestism in a more general sense. The positive aspects of the term are undercut to such an extent that it builds a continuous appearance of moral ambiguity in the characters of Achilles and Deidamia, and begins to become a catalyst to transgressive acts, rather than an inhibitor. In this way, pudor in the Achilleid plays a similar role to elegiac pudor, where the mere fact that it signifies a boundary - just like the gender reversals that Statius echoes with his transvestite Achilles - makes it exciting, subversive, and above all subject to transgression.

\section{$\underline{\text { Servitium Amoris }}$}

The gender-reversal that is so entwined in the Achilleid's treatment of pudor is intimately connected with the elegiac trope of servitium amoris. As I mentioned

\footnotetext{
${ }^{52}$ It is also worth comparing this with occurrence of pudor at the end to his transvestism at Ach. 1.863, where Achilles is compared to a lion ashamed to have served a cowardly master ("timidoque pudet servisse magistro") and Ach. 1.873, where Ulysses exhorts Achilles, "let cunning Thetis be ashamed to have feared for you thus." ("pudeatque dolosam sic pro te timuisse Thetin.") My first chapter discusses the problematic nature of his actions in this episode.

${ }^{53}$ So too at Ach. 2.44-45: "hoc excusabitur ense / Scyros et indecores, Fatorum crimina, cultus." ("by this sword Scyros and the disgraceful finery, a fault of the Fates, will be excused.")

${ }^{54}$ And while Ach. 1.661 is thought to be spurious, in that line Achilles calls it "ereptum pudorem."
} 
briefly in the discussion of pudor above, servitium amoris is founded on the notion that love for a woman has the potential to ensnare the lover, putting them under the direct control of the object of their desire. ${ }^{55}$ This ensnarement reverses the typical gender power dynamics of the relationship and ensconces the puella as the dura domina of her mollis servus, ${ }^{56}$ though it can objectify the desired puella to some extent, voyeuristically casting her into a fixed role without her consent or even (necessarily) knowledge. ${ }^{57}$ These operations need not be mutually exclusive, and each can contribute to the transgressiveness of the trope to some degree.

My second chapter highlighted some parallels between Statius' treatment of Achilles' transvestism at Ach. 1.580-3 and Propertius' treatment of Hercules' transvestism at 4.9.45-50 (as he attempts to gain entry into the grove of the Bona Dea). Each of these, in particular, makes use of a topos of spinning soft wool with the hero's rough hands. ${ }^{58}$ While Hercules' goal in bringing up his transvestite servitude under Omphale is simply to make himself appear less rough and dangerous, in aligning himself more closely with the maidens, Hercules' claim “et manibus duris apta puella fui" ("and despite my rough hands, I was an apt girl", Prop. 4.9.50) can be interpreted as a hypothetical realisation of servitium amoris, a reading that has significant consequences for the interpretation of Achilles' transvestism. Anderson demonstrates that 4.9 eroticises the puellae worshipping the Bona Dea by treating Hercules' request for entry as an elegiac paraclausithyron, ${ }^{59}$ and in this light even mentioning transvestism implies that he is potentially willing to take the role of a slave girl again, just as he did for Omphale. ${ }^{60}$

\footnotetext{
${ }^{55}$ Kennedy (1993), 48-9, Greene (2005), 61-2. One of the clearest examples of being enslaved via the gaze is Prop. 1.1.1 ("Cynthia prima suis miserum me cepit ocellis" - "Cynthia first captured miserable me with her eyes").

${ }^{56}$ O’Neill (2005), especially 264-6.

${ }^{57}$ See, for example, O’Neill (2005), 243-4, who briefly considers Prop. 1.3 in this light, but eventually dismisses that interpretation.

${ }^{58}$ While the pattern "dura... pensa manu" closely associates Statius' use of the topos with Propertian elegy, the motif of a transvestite hero doing women's work dates back at least as far as Euripides' Skyrioi, in which Odysseus rebukes Achilles for his transvestism ( $\operatorname{Tr} G F$ vol.

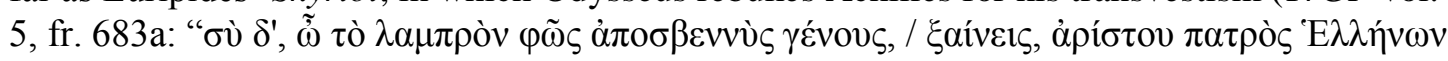
$\gamma \varepsilon \gamma \omega \dot{c} ; "$ - "And you, who extinguishes the radiant light of your house, are you combing [wool], though born to the best father in Greece?") and exhorts him to take up arms against Troy

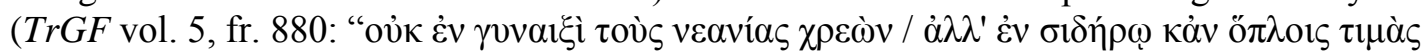

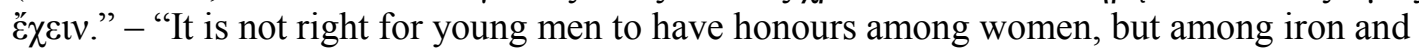
arms.") Note Collard and Cropp (2008), ad loc., and Heslin (2005), 197-98.

${ }^{59}$ Anderson (1964), 11-12.

${ }^{60}$ Heslin (2005) 122, Cyrino (1998) 223.
} 
The mythos in which Hercules dresses as a slave-girl in Omphale's service recurs in Prop. 3.11, ${ }^{61}$ in which Propertius lists a number of mythological exempla (including Achilles and Penthesilea) which illustrate the power women can hold over their lovers, thus excusing Propertius of his servile devotion to Cynthia. The overtones of the trope are particularly strong, in everything from the contrast between hard and soft, to the suggestion of otherworldly feminine power in the depiction of Propertius as "enthralled" ("addictum", Prop. 3.11.2), to the subject of the elegy itself: $^{62}$

quid mirare, meam si versat femina vitam et trahit addictum sub sua iura virum? ...

Omphale in tantum formae processit honorem, Lydia Gygaeo tincta puella lacu ut qui pacato statuisset in orbe columnas, tam dura traheret mollia pensa manu.

Prop. 3.11.1-2, 17-20

Why are you amazed if a woman overturns my life and draws an enthralled man beneath her laws? ... Omphale, the Lydian girl who was bathed by Gyges' lake, appeared so graced in her beauty that he who had built the pillars in a pacified world nevertheless teased out soft allotments [of wool] with a rough hand.

The Achilleid's depiction of heroic transvestism mirrors this passage even more than Prop. 4.9, setting up Hercules' time with Omphale as a model for Achilles' time on Scyros, as Thetis' exhortation to Achilles makes clear - note the verbal parallels between the hero's hard hand and soft objects, in particular:

cedamus, paulumque animos submitte viriles atque habitus dignare meo. si Lydia dura pensa manu mollesque tulit Tirynthius hastas... hac sine, quaeso, minas nubemque exire malignam.

Ach. 1.259-61, 65

Let us yield: moderate your virile spirit a little, and deem my garment worthy. If Tirynthius bore Lydian allotments [of wool] in his rough hand, and soft spears (thryrsi)... in this way, I beg, allow [me] to leave the threats and malicious cloud behind.

${ }^{61}$ It is worth noting that the mythos is popular: especially worthy of note in this context is Ovid's Her. 9.53-118, in which Deianira claims that Omphale has complete domination over Hercules, and that he has become effeminate (Her. 9.114: "tuque feri victor es, illa tui" - "and as you are the beast's (i.e. the Nemean lion's) conqueror, she is yours"). Cf. also A.A. 2.21722, using the same words. Also worth noting are Theb. X.646-49, and Seneca's Herc. Oet. 371-73.

${ }^{62}$ Of course, the contrast between dura and mollis is not applied to a domina and servus, but Propertius' inclusion of the dichotomy does nicely bring out the binary reversal of Hercules' external gender in his time with Omphale, which (especially in this context) is a strong representation of servitium amoris. 
Thetis' request of Achilles rather eloquently manipulates the youth's reverence for an earlier age of heroes that includes Hercules; ${ }^{63}$ there is a sense in which Thetis is not merely making an apology for transvestism by mentioning him, but providing an active incentive for it. ${ }^{64}$ The construction of this precedent does, however, evoke a sense of elegiac submission to feminine authority; Thetis uses verbs emphasising giving way ("cedamus" and "submitte" - and also "submittere" at Ach. 1.278), evokes the elegiac dichotomy of dura and mollis (in which the puella is usually dura and the poeta is usually mollis), and the reference to Hercules' spinning recalls Prop. 3.11, a poem about elegiac servitude, as demonstrated above. ${ }^{65}$

If it is fair to say that Statius constructs Achilles as an elegiac servilis amator, Deidamia is respectively his domina - the Omphale to his Hercules. ${ }^{66}$ Her initial appearance implies that she has elements of this role, leading her sisters, being compared to goddesses, and capturing Achilles' gaze, leading him to condemn himself to transvestite dress. As I established in my second chapter, at other points Deidamia and her sisters are likened to the amazons (Ach. 1.758 and 1.833), and at Ach. 1.94950 she herself begs Achilles to let her come to Troy with him to bear the standards of Mars (“cur non ego Martia tecum / signa feram?”). Such violent parallels, though only implied and not realised, lend her the kind of strength and potency normally ascribed to a man - not unlike that of an elegiac domina.

Achilles himself is not unaware of the effect which Deidamia is having upon him - in his monologue at the trieteris he claims that his transvestism is a prison (carcere, Ach. 1.625) and that he has been captured (captus, Ach. 1.637) by his love for her. Nevertheless, other elements of Statius' depiction of the Bacchic trieteris seem to invert the basic model of the trope; the transvestite Achilles is revered by the Scyrian maidens as if he himself were the domina (at Ach. 1.615-19, while he is still dressed as a woman, they seem captivated by his Bacchic dance), and the rape of Deidamia has been interpreted (at least to some degree) as a reassertion of masculine dominance - Achilles over Deidamia and his mother, and Roman men over the foreign, dangerous Bacchic ritual. ${ }^{67}$ In this Statius seems to be following the Ovidian model to

\footnotetext{
${ }^{63}$ See my earlier chapters for more on Achilles' reverence for Hercules et al.

${ }^{64}$ i.e. if Achilles wants to be as great as Hercules, transvestism is a step along the way.

${ }^{65}$ Cyrino $(1998,223)$ and Heslin $(2005,122)$ both comment on the elegiac side of Hercules' slavery under Omphale.

${ }^{66}$ As explored above in the context of pudor.

${ }^{67}$ Heslin (2005), chapter 6, especially 245-6 - addressed in my second chapter.
} 
some degree, as the courtship of Deidamia in the Ars Amatoria also ends in rape - in fact, it is the pre-eminent example of a "willing rape" (Ars 1.697-700). Richlin argues that for Ovid, "when we want to know the gender of the adolescent hero dressed in women's clothing, the signifier of his maleness is his ability to commit rape,"68 and Statius' rape of Deidamia is partially the result of Achilles' desire to prove his masculinity through a more violent kind of love ("teque marem... nec amore probabis?" Ach. 1.639). The rape is then a very Ovidian (and decidedly not servile) sentiment that realises the more voyeuristic aspects of the outwardly reverent gaze: an active male objectifies a passive female. ${ }^{69}$

But if the rape of Deidamia is a blatant departure from the model of servitium amoris that Achilles' relationship with the princess is built upon, it is momentary. At Ach. 1.650-56 he exhibits a very Ovidian puzzlement about why she is upset by the rape ("quid trepidas?... quid defles...? quid gemis...?" - "why do you tremble?... Why do you wail...? Why do you lament...?), ${ }^{70}$ while hastily reconstructing the facade of servitude and reverence that he has broken down only moments before:

\section{nec ego hos cultus aut foeda subissem tegmina, ni primo te visa in litore: cessi te propter, tibi pensa manu, tibi mollia gesto tympana.}

Ach. $1.652-5$

Nor would I have submitted to this disgraceful clothing, if I had not first seen you on the shore. I yielded because of you; for you [I spun] the allotment [of wool] with my hand; for you I bore the soft drums.

Achilles' attempt to console Deidamia returns to the mythos of Hercules and Omphale that his mother introduced as a model for his transvestism - "subissem" and "cessi", italicised above, mirror the "cedamus" and "submitte" of his mother's request in Ach. 1.259, while "pensa manu... mollia"71 again recalls the example of Hercules and Omphale that she raises at Ach. $1.260-61 .^{72} \mathrm{He}$ asserts that Deidamia's beauty motivated him to acquiesce to his mother's request, just as Omphale, "tantum formae

\footnotetext{
${ }^{68}$ Richlin (1992), 169.

${ }^{69} \mathrm{Cf}$. O'Neill (2005). Achilles' attempt to prove his masculinity certainly fails to some degree, as he returns to his feminine garb afterwards (cf. Heslin (2005), 274-5), but raping Deidamia is the first of the series of events that sees him break free of his transvestism. The violence of Achilles' expression of love will be considered in more depth in the next section.

${ }^{70}$ Ovidian in the sense that he seems to think, as per Richlin $(1992,169)$, that "pati is women's nature... the outcome of rape is happy."

${ }^{71}$ Hinds $(2000,240)$ argues that mollia is "ideological and programmatic, more than straightforwardly descriptive."

${ }^{72}$ Note that the motif also recurs at Ach. $1.580-3$, as mentioned in the previous chapter.
} 
honorem" ("so honoured for her beauty" Prop. 3.11.17), was the cause of Hercules' transvestism. In this way, Achilles' paraclausithyron refocuses the discourse of the rape from Achilles' action to Deidamia's reaction, but only superficially; although she is reintroduced as the object of Achilles' worshipping gaze - his domina - the damage has already been done. Achilles' rape of Deidamia irreparably breaks down the dynamics of gender-reversal, reforming its implicitly voyeuristic objectification of 'the gazed' into an explicitly literal objectification of femininity.

Nevertheless, while Achilles does reassert his masculinity at the Bacchic trieteris and thus this reassertion does not seriously constitute a departure from transgression. Rather than rejecting the model of servitium amoris completely, as would be appropriate for a Roman man concerned with the appearance of his pudor and the observance of true Roman mores, Achilles simply inverts the trope, first taking on the role of domina himself, when he is revered by the Scyrian maidens at Ach. 1.615-19, and then violently enacting the voyeuristic fantasies that the servile gaze implies. Finally, he implies that his transgressive actions are an affirmation of his slave-like devotion for Deidamia: an attempt to re-establish the authority of a transgressive elegiac trope as a model for his gender-reversal. The epic essentialism of the rape is thus also broken down; just as the multitude of imperfect intertextual models suggests, Achilles is incapable of acting like an elegiac amator, and unwilling to act like an epic hero.

\section{Militia Amoris and Elegiac Violence}

The violence of Achilles' rape is also approached within the elegiac dichotomy of arma and amor that is often represented through militia amoris. When Statius compares Achilles to Bacchus in his dancing at the trieteris, as I described in the previous chapter, it is implied that he is going off to war:

talis, ubi ad Thebas vultumque animumque remisit Euhius et patrio satiavit pectora luxu, serta comis mitramque levat thyrsumque virentem armat et hostiles invisit fortior Indos.

Ach. $1.615-18$

In this way, when Euhius has relaxed his face and spirit at Thebes, and satisfied his heart with the luxury of his fatherland, he frees the garland and head-dress from his hair and arms himself with the verdant thyrsus, and, mightier, he visits his Indian enemies. 
Mozley argues (and Hinds concurs) that this is an inverted comparison, in which the normally warlike Achilles dons Bacchus' effeminate garb, while the normally effeminate Bacchus prepares for war against the east. ${ }^{73}$ However, while this simile highlights the dichotomy between soft love and hard war that is already apparent, there is no need to treat it as inverted; the complexities of Achilles' transvestite status are accurately mirrored in the Bacchic simile. Up until this point, the warlike hero has been conspicuous by his absence. There is a perception, both prophetical and (for a Roman audience) retrospective, that Achilles will eventually prove himself in battle, but he has been wearing women's clothing for some time now. He approaches the trieteris not as a warrior, but as one of the chaste maidens of Scyros, or (from his perspective) as a man who has been made soft by his amor for Deidamia. It is only through the maenadic - almost amazonian - festival that he begins to become warlike: at Ach. 1.602, he is part of a feminine agmen ("agmine femineo"), a term which can be used to describe an army, and this imagery is reiterated in the following line, where he is "leading the standards of a troop of maidens" ("virgineae ducentem signa catervae" - Ach. 1.603). Then, immediately before the simile comparing him to Bacchus, Achilles "encircles his golden temples with crimson bands and brandishes the garlanded missile" ("cinxit purpureis flaventia tempora vittis / vibravitque gravi redimitum missile dextra" - Ach. 1.611-12). This is not a warlike Achilles donning Bacchic effeminacy to disguise himself among the women, but an effeminate Achilles donning the implements of a Bacchic war - he has his 'troop', his 'armour', and his 'weapon'.

As Hinds makes clear, the tension between arma and amor is a central feature of the Achilleid in other ways as well. The descriptions of Deidamia as Pallas without her aegis (Ach. 1.297-300), transvestite Achilles as Therapnean Hecate (Ach. 1.344-48) and the wider group of Scyrian maidens as amazons (Ach. 1.758-60 and 830-34) all weave war-imagery into the peaceful Scyrian locale, as does Deidamia's offer to carry the martial standards with Achilles at Troy ("cur non ego Martia tecum / signa feram?" - Ach. 1.949-50). Just as Ovid tells Macer that "golden Love is not silenced in the midst of Mars" ("nec... arma canenti / aureus in medio Marte tacetur Amor" Am. 2.18.35-6), so too arma is not excluded from Statius' amatory passages, and forms the backdrop to the rape of Deidamia.

\footnotetext{
${ }^{73}$ Mozley (1928), op. cit. Hinds (2000, 239) agrees.
} 
Examples of violent tensions in erotic elegy that inform this interpretation of Deidamia's rape are numerous: at 3.5.2 Propertius describes his relationship as a form of war ("sat mihi cum domina proelia dura mea." - "the hard battles with my mistress are enough for me.”); at 2.1.13 he describes a literal fight (“nuda erepto mecum luctatur amictu" - "she wrestles with me naked, her clothing torn away"); and of course Ovid's 'willing rape' in the Ars Amatoria, though even he has a warning against taking things too far:

$$
\begin{aligned}
& \text { pugnabit primo fortassis, et "improbe" }{ }^{\text {"74 }} \text { dicet: } \\
& \text { pugnando vinci se tamen illa volet. } \\
& \text { tantum ne noceant teneris male rapta labellis, } \\
& \text { neve queri possit dura fuisse, cave. }
\end{aligned}
$$

Perhaps she will fight at first, and call you 'wicked'; nevertheless she will want to be conquered in the fighting. Only be careful, lest your rapes wrongly harm her delicate lips, or she is able to complain that you are hard!

Similarly, D. F. Kennedy argues that Tibullus "[ratifies] the legitimate limits of violence", and "[ordains] the distinction between vis in 'love' and in 'war".:"75

$$
\text { quater ille beatus }
$$

quo tenera irato flere puella potest.

sed manibus qui saevus erit, scutumque sudemque is gerat et miti sit procul a Venere.

Tib. 1.10.63-66

Four times blest is he at whose anger his tender girl can weep. But the one who is going to be savage with his hands should take up his shield and stake and get far away from gentle Venus.

It would be naive to assume that these limitations on sexual violence are operative in all poetry - or even all elegy - and indeed, the sexualisation of violence is a topic far broader than I can satisfactorily address here. ${ }^{76}$ Nevertheless, if (as Sanna has persuasively argued ${ }^{77}$ ), Achilles' seduction of Deidamia follows the model presented by Ovid in the Ars Amatoria, it does not seem at all unreasonable to assess the rape the last step on the seductive path taught by the praeceptor amoris - against the imitations on sexual violence proposed by Ovid himself. Of course, as I have already demonstrated in my second chapter, Achilles' violence against Deidamia is excessive - she is unwilling, the stuprum evokes the echoes of Livy's dangerous Bacchic cults,

\footnotetext{
${ }^{74}$ It is worth noting that Achilles is called improbus at Ach. 1.569, shortly before the rape.

${ }^{75}$ Kennedy (1993), 56. The example of Tibullus 1.10 is also taken from here, of course, and the translation is his for the sake of consistency.

${ }^{76}$ For further treatment, see Fredrick (1997), and Richlin (1992).

${ }^{77}$ Sanna (2007), 214-15.
} 
and there are no overtones of a playful elegiac rixa that might be expected to come at the end of the praeceptor's path.

Like Achilles' claim of servile devotion to Deidamia, the martial imagery of the Bacchic trieteris portrays him as an elegiac amator (though this time a 'miles', not a 'servus') and implies that the upcoming rape is a form of amatory warfare against her. ${ }^{78}$ But again, the trope is not left intact; it is as if the young hero takes the metaphor of force and dominance too literally. Statius' portrayal of the rape as a violation of the Ovidian amator's program of elegiac love suggests that Achilles is incapable of acting appropriately not just within his own society, but even within a literary framework that prides itself on transgression.

\section{Conclusion}

Right from the outset, Statius signals that his heroic but transgressive Achilles will be developed through the use of "un-epic" features, such as elegiac tropes and intertexts. While the young hero's warlike future is often alluded to, his transvestite youth is depicted as though he is an elegiac amator. His lust for Deidamia governs his actions, and pudor, which should stop him from donning women's clothing, becomes yet another boundary that his transgressive nature demands he cross. Indeed, he depicts himself as a slave and a soldier of love, completely at the mercy of amor. While his transgressive nature takes him too far with the rape of Deidamia, he then refuses to adopt the epic heroism that might justify his actions, instead choosing to return to his transvestite persona and to maintain at least a semblance of devotion towards her.

Within the supposedly epic framework of the Achilleid, Statius' constant manipulations of elegiac intertexts are problematic, but in fact, the very notion of epic essentialism is problematic in a poem about cross-dressing, love, and the constant violation of boundaries. ${ }^{79}$ Achilles may fail in his role as an elegiac amator, but he also fails to be an appropriate epic hero, and rather maintains a transgressive style of heroism that rejects boundaries or easy categorisation. This model of constructing boundaries in order that they may be transgressed is, at its core, elegiac, and the

\footnotetext{
${ }^{78}$ At the same time it foreshadows his upcoming departure from Scyros - he arms himself as though he is Bacchus going off to war, and commits a rape that moves him one step closer to Troy.

${ }^{79}$ McAuley (2010), 58.
} 
emphasis that elegy places upon on love and transgression is particularly appropriate to the "un-epic" episodes of Achilles' youth. Thus elegy enables the problematic nature of the Homeric Achilles to be preserved in a post-Augustan era of Latin literature. 


\section{Conclusion: An Elegiac Epic}

The Roman mythos of Achilles is that he is a hero of extremes, extra-ordinary in every way, and above all else, incapable of fitting in with his society. He is the best of the Achaeans, swift, beautiful and quick-witted, but also the beast of the Achaeans, pitiless, self-serving and violent. He is often constructed as an idealised model for masculine youth, and yet he cross-dresses, repeatedly falls passionately in love, ${ }^{1}$ and puts his personal feelings and pride above the good of his allies. Chronologically he is one of the last heroes, following the foundation myths, Hercules' sack of Troy, and the Argonauts (of which his father is sometimes a member), but the far-reaching importance of the Iliad as a literary model simultaneously elevates him to the place of the first literary hero, and indelibly associates him with the epic genre.

From the beginning of the Achilleid, Statius signals that the paradoxes and passionate transgressions of this quintessential 'Achillean character' will be mirrored in his hero. The first lines signal an epic program built upon a Homeric foundation, but the rest of the proem manipulates elegiac language and even includes a Flavian recusatio. This generic ambiguity is maintained throughout the poem, as themes of the upcoming war and Achilles' dangerous potential are juxtaposed with his lust for Deidamia and his all-too persuasive transvestism, which he himself portrays as a form of elegiac servitude. The liminal concepts of militia amoris and pudor smooth the epic's transitions between these themes, and at the same time, privilege a moral ambiguity and heightened awareness of problematic elements that emphasises Statius' generic transgression alongside Achilles' gender transgression.

This emphasis on boundaries is not only developed through elegy, however. When Achilles first dons women's clothing, the moulding of his appearance by Thetis is so effective that it constructs new boundaries of appropriate action. Even while the effeminacy of Achilles' transvestism is so inherently problematic for a masculine hero, it is implied that the mores directly operative upon him at that time are not those of a masculine hero, but of a Scyrian maiden. The centrepiece of the epic, the multivalent Bacchic trieteris and rape of Deidamia, is similarly a fascinating amalgamation of

\footnotetext{
${ }^{1}$ It would be mistaken to assume that leaving Scyros would necessarily bring any real closure to his amatory side; among the other potential loves of Achilles are Deidamia, Briseis, Patroclus (described at Ach. 1.174 as "magno iam tunc conexus amore" - "even then joined [to Achilles] in great love"), Troilus, Polyxena, and Penthesilea.
} 
tropes and intertextual reminiscences, each of which imposes expectations on how Achilles will behave. In the end, none of them fits his behaviour, and even understanding the rape of Deidamia as a realisation of the Scyrian women's chaste potential for violence - as with Artemis and the amazons - builds a model in which the end of his transvestism becomes dangerous and problematic. A failure to transgress in an 'appropriate' manner is thus construed as transgressive in itself.

Nevertheless, these ambiguities are still tempered by connections to the excessively violent and pitiless hero of the Iliad. Achilles' description of his education in the second book of the Achilleid reads as a preparation for the Trojan War, and it is laced with instances of savagery (such as eating the raw flesh of wolves and lions, Ach. 2.98-102) and longing for fame (such as marvelling at deeds of the ancient heroes, Ach. 2.157-58). In this way, the cyclical composition of the epic recalls Achilles' dangerous potential in the first book, as when he returns from the hunt "sadistically" taunting the cubs whose mother he has just slain (Ach. 1.168-70), or when he sings himself into the poetic tradition of heroes such as Hercules and Theseus by alluding to his own birth (Ach. 1.188-94). And in fact, this arrogance is not misplaced: Achilles' heroism is not the cultured, civilised heroism of Chiron overcoming his wild nature or "pius Aeneas" coming to terms with his fate and finding a new home for his people. Rather, Statius' Achilles constructs himself as a transgressive hero like Hercules, who cross-dressed, violated rituals, and murdered his family, and Bacchus, whose liminal appearance and quintessentially divine potential for violence make him as problematic as he is idealised. And whether through Sperchius' early mourning or Thetis' fear for her son, the Achilleid is constantly mindful of Achilles' inevitable fate: to lose Patroclus, to wreak a bloody vengeance, and to die, still young, on the Trojan shore.

Within such a strongly epic frame, Statius' reliance on elegy seems paradoxical. In order to negotiate this paradox, it is perhaps worth revisiting the argument of Barchiesi, that the Achilleid is "una sorta di super-epos", but is undercut by the timbre of "le forze di disturbo - erotiche, anti-epiche" ("the forces of disorder erotic, anti-epic"). Barchiesi suggests, then, that Statius' central theme becomes an attempt to reconcile these contradictory elements of "teatro programmatico". ${ }^{3}$ While I

\footnotetext{
${ }^{2}$ Arico (1986), 2937.

${ }^{3}$ Barchiesi (1996), 55-62.
} 
cannot disagree with the notion that the Achilleid is an epic, and that in fact it may even be a "super-epic", Barchiesi's argument requires a significantly heightened selfawareness of the thematic differences between epic and elegy that in practice is not nearly so clear cut. "Erotic" or "anti-epic" themes, such as love and desire, are not at all unusual within a Latin epic: for just one example, the Aeneid devotes an entire book to Aeneas' dalliance with Dido. How then is the Achilleid to be read as "unepic", while the Aeneid is the seminal epic of the Roman era?

The notion of epic as the poetry of arma and elegy as the poetry of amor is built upon the influence of Augustan elegy - and especially the poetry of Ovid and Propertius. ${ }^{4}$ Ironically, then, the very concept of a "super-epos" is derived in some measure from the application of elegiac rules. The Achilleid's "programmatic theatre" is not simply formed by undercutting an essential "epicness" with elegiac reminiscences, but by using this elegiac trope, that epic is arma and elegy is amor, both to reinforce and simultaneously to disrupt the epic status of the subject. Just as Achilles' transvestism contributes to his heroic stature by emphasising his extraordinary nature, so too the "literary transvestism" of the Achilleid contributes to its essential "epicness" just as surely as it undercuts it. ${ }^{5}$

In conclusion, it is clear that the Achilleid is heavily invested in concepts of transgression. Statius alternates between describing the violence of Achilles' savagery and the power of his passionate desire. Like elegy, the epic further problematises such behaviour by using intertextual relationships to delineate numerous boundaries, and juxtapose them with Achilles' differences. And beyond simply stimulating interest for the reader, this portrayal of a transgressive hero is consistent with the character of Achilles adumbrated in the Iliad: the use of elegiac intertexts provides a medium through which such a problematic Greek hero may become legible and accessible for an educated Flavian audience.

It is impossible to know whether the Achilleid would have continued this generic transgression alongside its transgressive hero. There is certainly room to develop amatory strands in his many romances alongside the heroic and bestial strands of his many aristeia, and the combination of these strands could have made him a better rounded character, and thus made his death a truly tragic and impressive end to

\footnotetext{
${ }^{4}$ Hinds (2000), 224-36

${ }^{5}$ The notion of "literary transvestism" is suggested by Debrohun $(1994,61)$, with respect to Propertius' fourth book, and Hercules in 4.9.
} 
the epic. To some extent the question is even irrelevant, as the epic is cohesive and beautiful as a work of literature even in its unfinished state. But whichever way Statius might have taken his little epic, there is little doubt that Achilles as a hero and the Achilleid as an epic could have maintained their transgressive natures far more easily than they could have set them aside. 


\section{Works Cited}

Anderson, W. S. (1964). “Hercules Exclusus: Propertius, IV, 9.” American Journal of Philology 85: 1-12

Arico, G. 1986. 'L' 'Achilleide' di Stazio: tradizione letteraria e invenzione narrativa." ANRW II.32.5: 2925-2964.

Barchiesi, A. 2005. "Masculinity in the 90s: The Education of Achilles in Statius and Quintilian.” In Michael Paschalis, ed. Greek and Roman Imperial Epic. Heraklion. 47-75.

_ 1996. "La Guerra di Troia non avrà luogo: il proemio dell’Achilleide di Stazio.” AION (filol) 18: 45-62.

Barton, C. 2001. Roman Honour: The Fire in the Bones. Berkeley

Benker, M. 1987. Achill und Domitian: Herrscherkritik in der "Achilleis" des Statius. Erlangen-Nürnberg: Friedrich-Alexander-Universität.

Brouwer, H. H. J. 1998. Bona Dea: The Sources and a Description of the Cult. New York.

Brown, S. A. 2005. Ovid: Myth and Metamorphosis. London.

Cairns, F. 2006. Sextus Propertius: the Augustan Elegist. Cambridge.

Cameron, A. 2009. "Young Achilles in the Roman World.” Journal of Roman Studies 99: 1-22.

Chaplin, J. D. 2000. Livy's Exemplary History. Oxford.

Collard, C. and M. Cropp. 2008. Euripides. Fragments., Mass.

Conte, G. B. 1986. The Rhetoric of Imitation: Genre and Poetic Memory in Virgil and other Latin Poets. Ithaca, New York.

Cyrino, M. S. 1998. "Heroes in D(u)ress: Transvestism and Power in the Myths of Herakles and Achilles". Arethusa 31: 207-241.

Davis, P. J. 2006. “Allusion to Ovid and others in Statius' Achilleid.” Ramus 35: 129143.

Debrohun, J. B. 1994. “Redressing Elegy's Puella: Propertius IV and the Rhetoric of Fashion." Journal of Roman Studies 84: 41-63.

Dilke, O. A. W. 1963. "Magnus Achilles and the Statian Baroque.” Latomus 22: 498503.

1954. Statius. Achilleid. Cambridge.

Edmunds, L. 2001. Intertextuality and the Reading of Roman Poetry. Baltimore. 
Fantham, E. 1979. "Statius' Achilles and his Trojan Model." CQ 29: 457-462.

1999. "Chironis Exemplum: on teachers and surrogate fathers in Achilleid and Silvae." Hermathena 167: 59-70.

Fairclough, H. R. 1916. Virgil. Eclogues, Georgics, Aeneid (2 vols). Cambridge, Mass.

— 1926. Horace. Satires, Epistles, and Ars Poetica. Cambridge, Mass.

Feder, T. H. 1978. Great Treasures of Pompeii \& Herculaneum. New York.

Feeney, D. 2004. "Tenui...latens discrimine: spotting the differences in Statius' Achilleid." MD 52: 85-105.

Frazer, J. G. 1921. Apollodorus. The Library. Cambridge, Mass.

1912. Spirits of the Corn and of the Wild. London.

Fredrick, D. 2002. The Roman Gaze. Baltimore.

Garber, M. B. 1992. Vested Interests: Cross-dressing and Cultural Anxiety. New York.

Goold, G. P. 1990. Propertius. Elegies. Cambridge, Mass.

—_ (ed.) 1913. Catullus, Tibullus, Pervigilium Veneris. Cambridge, Mass.

Greene, E. 2005. "Gender Identity and the Elegiac Hero in Propertius 2.1.” In R.

Ancona and E. Greene, ed. Gendered Dynamics in Latin Love Poetry. Baltimore.

Gunderson, E. 2000. Staging Masculinity: the Rhetoric of Performance in the Roman World. Ann Arbor.

Hall, J. B., A. L. Ritchie and M. J. Edwards (eds). 2007. Statius. Thebaid and Achilleid (3 vols). Newcastle, UK.

— 1969. Claudian. De Raptu Proserpinae. Cambridge.

Heslin, P.J. 2005. The Transvestite Achilles: Gender and Genre in Statius' Achilleid. Cambridge.

Hinds, S. 2000. "Essential Epic: Genre and Gender from Macer to Statius.” In Mary

Depew and Dirk Obbink, eds. Matrices of Genre: Authors, Canons, and Society.

Cambridge, Mass. 221-264.

1998. Allusion and Intertext: Dynamics of Appropriation in Roman Poetry. Cambridge.

Janan, M. W. 2001. The Politics of Desire: Propertius IV. Berkeley.

Kampen, N. B. 1996. 'Omphale and the Instability of Gender'. In N. B. Kampen, ed.

Sexuality in Ancient Art. Cambridge. 233-246.

Kennedy, D. F. 1993. The Arts of Love. Cambridge.

King, K. C. 1987. Achilles: Paradigms of the War Hero from Homer to the Middle Ages. Berkeley. 
Leader, R. E. 2000. “The David Plates Revisited: Transforming the Secular in Early Byzantium." The Art Bulletin 82: 407-427.

LeGuin, U. K. 1974. The Dispossessed: an Ambiguous Utopia. New York.

Lindheim, S. H. 1998. "Hercules Cross-dressed, Hercules Undressed: Unmasking the Construction of the Propertian amator in Elegy 4.9." American Journal of Philology 119: 43-66.

Mackie, C. J. 1997. “Achilles' Teachers: Chiron and Phoenix in the Iliad.” Greece and Rome 44: 1-10.

Marks, R. 2005. From Republic to Empire: Scipio Africanus in the Punica of Silius Italicus. Peter Lang, Studien zur klassichen Philologie, B. 152.

McAuley, M. 2010. “Ambiguus Sexus: Epic Masculinity in Transition in Statius' Achilleid." Akroterion 55: 37-60.

Méheust, J., ed. 1971. Achilléide. Paris.

Mendelsohn, D. 1990. "Empty Nest, Abandoned Cave: Maternal Anxiety in ‘Achilleid' 1". Classical Antiquity 9: 295-308.

Miller, F. J. 1916-17. Ovid. Metamorphoses (2 vols). Cambridge, Mass.

Monro, D. B., T. W. Allen, and C. M. Bowra. 1920. Homeri Opera. Oxford.

Mozley, J. H. 1934. Valerius Flaccus. Argonautica. Cambridge, Mass.

1923. Statius. Thebaid 5-12, Achilleid. Cambridge, Mass.

Murray, A. T. 1919. Homer. Odyssey. Cambridge, Mass.

Nauta, R. 2006. “The Recusatio in Flavian Poetry.” In Ruurd R. Nauta, Harm-Jan van Dam, and Johannes J. L. Smolenaars, ed. Flavian Poetry. Brill: Mnemosyne.

Oliver, J. H. 2011. Beyond Tribadism: Alternate Discourses on Female Homoeroticism in Greek and Latin Literature. M.A. Thesis, Victoria University of Wellington.

O’Neill, K. 2005. “The Lover's Gaze and Cynthia's Glance.” In R. Ancona and E. Greene, ed. Gendered Dynamics in Latin Love Poetry. Baltimore.

Parkes, R. 2008. "The Return of the Seven: Allusion to the Thebaid in Statius' Achilleid." American Journal of Philology 129: 381-402.

Peiper, R., and G. Richter. 1921. Seneca. Tragoediae. Leipzig.

Perrin, B. 1919. Plutarch. Plutarch's Lives. Cambridge, Mass.

Pomeroy, A. 2010. “To Silius through Livy and his Predecessors.” In A. Augoustakis. Brill's Companion to Silius Italicus. Leiden. 
Rabel, R. J. 1990. "Apollo as a Model for Achilles in the Iliad." American Journal of Philology 111: 429-440.

Rhorer, C. C. 1980. "Red and White in Ovid's Metamorphoses.” Ramus 9: 79-88.

Richlin, A. 1992. "Reading Ovid’s Rapes.” In Amy Richlin, ed. Pornography and Representation in Greece and Rome. New York.

Robbins, E. 1993. "The Education of Achilles.” Quaderni Urbinati di Cultura Classica 45: 7-20.

Robertson, D. S. 1940. “The Food of Achilles.” The Classical Review 54: 177-180.

Rosati, G. 1994. 'Momenti e forme della fortuna antica di Ovidio: l'Achilleide di Stazio', in M. Picone and B. Zimmermann (eds.), Ovidius redivivus. Stuttgart, 43-62.

1992. "L'Achilleide di Stazio, un'epica dell'ambiguità.” Maia 44: 233-266.

Rudd, N. 2004. Horace's Odes and Epodes. Cambridge, Mass.

Sanna, L. 2007. "Achilles, the Wise Lover and his Seductive Strategies (Statius, Achilleid 1.560-92)". Classical Quarterly 57: 207-215.

Schlesier, R. 2011. "Der bakchische Gott.” In R. Schlesier, ed. A Different God? Dionysos and Ancient Polytheism. Berlin.

Shackleton-Bailey, D. R, ed. 2003. Statius. Thebaid 8-12 and Achilleid. Cambridge.

— 2003. Statius. Silvae. Cambridge.

1956. Propertiana. Cambridge.

Showerman, G. 1931. Ovid. Heroides and Amores. Cambridge, Mass.

Snell, B., and H. J. Mette. 1955. Lexikon des frühgriechischen Epos (vol. 2).

Göttingen.

Staples, A. 1998. From Good Goddess to Vestal Virgins: Sex and Category in Roman Religion. New York.

Sutton, D. 1977. “The Greek Origins of the Cacus Myth.” Classical Quarterly 27: 391-393.

Tipping, B. 2010. "Virtue and Narrative in Silius Italicus' Punica." In A. Augoustakis, ed. Brill's Companion to Silius Italicus. Leiden.

Trimble, J. F. 2002. "Greek Myth, Gender, and Social Structure in a Roman House: Two Paintings of Achilles at Pompeii." Memoirs of the American Academy in Rome. Supplementary Volume 1:225-248.

Welch, T. S. 2004. "Masculinity and Monuments in Propertius 4.9." American Journal of Philology 125: 61-90. 
Weissenborn, W., and H. J. Miller. 1898. Titus Livius. Ab Urbe Condita. Leipzig.

Whitehorne, J. 2000. "Menander's “Androgynos': Plot, Personae, and Context.” Hermes 128: 310-319

Wiseman, T. P. 1974. "Clodius at the Theatre." In T. P. Wiseman, ed. Cinna the Poet, and Other Roman Essays. Leicester.

Woods, M., and R. Copeland. 1999. "Classroom and Confession.” In D. Wallace, ed. The Cambridge History of Medieval English Literature. Cambridge. 376-406.

Wyke, M. 1995. “Taking the Woman's Part: Engendering Roman Love Elegy.” In A. Boyle, ed. Roman Literature and Ideology. Bendigo. 